\title{
THE LANGUAGE OF THE NORTHUMBRIAN GLOSS TO THE GOSPEL OF ST. MARK.
}

In compiling this little book on the language of the Lindisfarne St. Mark (Skeat's Edition 1871), I have taken for my model the well-known Grammar of Dr. Uno Lindelöf "Die Sprache des Rituals von Durham, 1890".

My sole endeavour has been to arrange in a recognised order the material before me. I have not attempted to advance new theories, still less to demolish old ones, the chief features of the Northumbrian dialect of this period being already so exhanstively discussed by Dr. Lindelöf.

I am anxious to tender my thanks for help to Dr. Murray, Professor Sievers, and Professor Skeat; and it is with much pleasure that $I$ take this opportunity of expressing my sincere gratitude to Professor Wright not only for suggesting the work, but also for so constantly assisting me throughout its progress; and to Professor Napier to whom I am indebted for almost all the explanations here proffered of the difficult and obscure words in the text. Indeed but for their sympathy and encouragement the work could never have been accomplished.

\section{Contents.}

Part I. Phonology.

A. The Vowels of the Stem Syllables.

Chapt. I. Short Vowels. (§§ 1-37.)

Chapt. II. Long Vowels. (\$§ 38-55.)

Chapt. III. Diphthongs. (\$§ 56-64).

B. The Vowels of Medial and Final Syllables.

Chapt. IV. Suffixes, Prefixes, \& Compound Words. (\$§ 65-75).

Chapt. V. Syncope of Middle Vowels. (\$§ 76-79).

$$
\text { C. The Consonants. }
$$

Chapt. VI. Semi-vowels. ( $\$ 80-\delta 3$.)

Chapt. VII. Liquids and Nasals (\$§ 84-90).

Chapt. VIII. Non-Sonorous Consonants.

I. Labials (\$§ 91-93).

II. Dentals (\$§ 94-98).

III. Gutturals and Palatals (\$§ 99-102).

Gemination of Consonants. (\$§ 103-104). 
Part II. Inflection.

Chapt. IX. Personal Endings of Verbs. ( $\S 105-123)$.

Chapt. X. Tense-Formation of Strong Verbs. (\$§ 124-131).

Chapt. XI. Tense-Formation of Weak Verbs. (\$§ 131-136).

Chapt. XII. Minor Groups (\$§ 137-141).

Chapt. XIII. Declension of Nouns.

A. Vocalic or Strong Declension (\$§ 142-155).

Chapt. XIV. B. Weak Declension (\$\$ 156-162).

C. Minor Declensions ( $\S \S 163-166)$.

Inflection of Proper Names (\$§ 167).

Chapt. XV. Adjectives (\$§ 168-175).

Adverbs ( $\$ \$ 176-177)$.

Chapt. XVI. Numerals ( $\S 178-180)$.

Chapt. XVII. Pronouns. (\$§ 1\$1-186.)

\section{Abbreviations.}

Bout. $=$ Die vier evangelien in alt-nordhumbrischer sprache von Karl Wilhelm Bouterwek.

Brown $=$ Die sprache der Rushworth glossen zum evangelium Matthäus und der mercische dialekt von Edward Miles Brown.

B-T. = Bosworth-Toller, Anglo-Saxon Dictionary.

C. = Altwestsïchsische Grammatik von P. J. Cosijn.

C. N. = Critical Notes to the text of St. Mark, referred to by page.

H. = Zur altnordhumbrischen laut- und flexionslehre von Dr. H. Hilmer.

Kluge Nom. Stamm. = Nominale Stammbildungslehre der altgermanischen dialecte.

$\mathrm{L}=$ Die sprache des rituals von Durham, ein beitrag zur altenglischen grammatik van Uno Lindelöf.

P. B. B. = Beitrïge zur geschichte der deutschen sprache und literatur, herausgegeben von $H$. Paul und W. Braune.

P. G. = Grundriss der germanischen philologie, berausgegeben von $H$. Paul, band I.

Pog. = Zur lantlehre der griechischen, lateinischen und romanischen lehnworte im Altenglischen, von Alois Pogatscher.

S. = Angelsïchsische grammatik von E. Sievers, zweite auflage. 1886.

Sw. O. E. T. = The Oldest English 'I'exts edited with Introductions and a Glossary by Henry Sweet.

Sw. II. E. S. = A History of English Sounds from the earliest Period. by Henry Sweet.

Z. = Die sprache des kentischen psalters (Vespasian A. I), ein beitrag zur angelsächsischen grammatik von Rudolph Zeuner.

Pref. refers to the "Argumentum" and "Capitula Lectionum" contained on pp. $1-5$ of the text.

A figure in brackets after a word means the number of times the word occurs, including any references preceding - thus: long VII. 6, IX. 21 etc. (9), means that nine forms of long occur. 


\section{Part I. Phonology.}

\section{A. The Vowels of the Stem Syllables.}

Chapter I. Short Vowels.

a. cases.

8 1. $a=$ WGmc. $a$ occurs in St. Mark in the following

1) In originally open syllables where the following syllable contains a guttural vowel (S. \& 50.1. and anm.): aron IV. 15,31 etc. (5), aro gie IV. 40, V. 39, VII. 18, IX. 41 (v. Kluge P. G. § 36. 6, p. 373); daga I. 13, dagas II. 20 etc. (4), -dagum I. 9 etc. (11), (v. § 143. III), -ðagana XVI. 2 ( $\delta$ for $d$ v. § 96); fadores VIII. 38, XI. 10, XIV. 62 margin (faedores Pref. 3. X.), (Jone fader V. 40 beside the regular form faeder $\mathbf{v}$. 3.1 ); ofer-fara X. 25; fato III. 27; haga XII. 1; magon II. 19 etc. (7), mago ge X. 38 (v. § 137. 7); nacod XIV. 51, 52, ge-nacedon II. 4; hraccentegum (catenis) V. 3, 4, hracengo V. 4 (v. § 68. 4); on-sacca (inf.) Pref. 1. 15, (onsacco ic negabo XIV. 31); mordor-slago VII. 21; onsuarade III. 33, -onsuarede XIV. 61, XV. 5, 9 (ondsuorade XIII. 2, S. § 51, and onsucerede XIV. 48, geondsucerde XII. 34, onswaerega XIV, 40); getaled (reputatus) XV. 28 (for getalod, v. S. § 416. anm. 6); wacan (uigiliam) VI. 48, Pref. 3. XIX, gewaccas (uigilate) XIII. 35 (beside waccas v. § 23. 4). The vowel of grasum IV. 32, is due to levelling out from the forms where $a$ is regular. For the converse of this levelling v. tales Pref. 1. 12.

2) Before $l+$ cons.: aldor I. 44 etc.; halfe I. 45; gehalp V. 26; gesalde VI. 7 etc.; and before $r+$ cons.: $\arg$ VIII. 38; gedarste XII. 34; award XV. 33. For further examples and for the occurrence of breaking to $e a \mathrm{v} . \S 12$.

Lengthening of $a$ before the consonant group $l d$ is marked by an accent in sáld VIII. 12, sâlde XIII. 34 (v. § 38. 4).

3) Before nasals: with the exception of the form stando (mora) VI. 35, a remains unchanged to $o$ only in the case of the $1^{\text {st }}$ and $3^{\text {rd }}$ pers. sg. Pret. Indic. of the strong verbs of ablaut III. cl. I. (S. § 386. anm. 3): geband VI. 17; blann IV. 39, VI. 51; cann XIV. 68 (conn XIV. 71; etc. (34), v. § 126. II).

4) In close syllables not included under 2) and 3): ah (sed) I. 45 etc. (42), ahne II. 19, IV. 21, VI. 3, XI. 17; asca VI. 11; habba, habbas VI. 18, VIII. 16 etc. (24), (v. § 136. 1); tal 
(expositionem) Pref. 1.12 (L. § 1. 4, p. 2). In fasne (fimbriam) VI. 56, the close syllable is perhaps due to metathesis. v. B-T. fnces. Rushw. has forse. For gelahte VIII. 32 etc. v. § 18.

5) In the following loan-words: cuic almus (uictima) IX. 49, calic IX. 41, X. 38, 39 etc. (5), calica VII. 4, 8; camel X. 25 , camelles I. 6 ; latin V. 41; sacerd XIV. 53, 60, 61, 63 ete. (23), (v. §§ 142. II, 143. I, II), beside these forms with $a$, occurs the form sacerd-hâd Pref. 1.16 where the vowel has been influenced by the following palatal $c$; trahtade IV. 34, getrahtad V. 41 etc. (6), (v. $§ \$ 134.135)$; asales IX. 42, asalde Pref. 4. XXXV (v. § 96); carre (petra) XV. 46; maccalic (oportunus) $=0$. N. makligr VI. 21 .

Note. The $a$ in camel, sacerd, originally short in Latin, is given as long in $\mathrm{OE}$ in Pog. $\$ 27$, p. 31 : "In gelehrten entlehnungen gelten die haupttonigen silben als lang." For câmel v. $\S 189$, p. 117: sâcerd $\S 27$, p. 31, $\S 186$, p. 117; calic, calic v. $\S \S 44,216$ etc.; WS oelmesse, ô.lmesse $\mathrm{v} . \S 237$, p. 140 , the above form almus is abnormal.

$a$ before Nasals.

8. WGmc. $a$ before Nasals appears regularly as $o$ in all other instances beyond those mentioned in $\S 1$. 3). The examples are:

1) Before simple $m$ : from I. 5, 9, 26 etc.; lichoma VI. 29 etc. (13), (v. §156); noma III. 16 ete. (13); somnung I. 21, 23 etc. (13) (v. \$§ 146, 147), gesomniað XIII. 27 etc. (ङ), (v. §§ 134. 1; 135. 1). For embeht-monn IX. 35 etc. (8), (v. § 18), v. S. $\S 93$, Nachtr.

2) Before $m+$ cons. : huommes XII. 10; ombor XIV. 13, ombora VII. 8; nomb VII. 19.

3) Before simple dental $n$ : hona XIV. 30, 68, 72, honcroed XIII. 35 ; huon II. 16 , XIV. 4, XV. 34 etc. (8), (v. § 185); eyhuona I. 45, huona VIII. 4, XII. 37; huone XI. 25; monig, monig-fald I. 34, IV. 33, V. 9, X. 46, etc. (29), (with $i$-umlant menig etc. (22), v. § 23. 2); on-, as prefix, onsione I. 2, XII. 14, XIV. 65, onweaeld XIII. 34; on (Prep.) I. 4, 6 ete. (v. S. § 51); Jon: aefter-, for-, of- I. 15, 16, 22 etc. (134), (v. \$182), ठon (quam) IX. 43, 47, XIV. 30, Pref. 1. 11, jone (Dem. Pron.) always with o I. 2, 19 etc. (45), jone (quem) IX. 36, X. 38, 39 ete. (9), (beside dene XI. 2), Jone (illun, elum) VIII. 22, XIV.25, 44 (beside dene V. 15,24 etc. (15), v. § 182, S. § 65, anm. 2); Jona I. 19, VI. 1,10 etc. 
4) Before $n+$ cons.: conn XIV 68 (§ 1.2); hond I 31,41, etc. (29), (v. § 154); huonne VIII. 19 (huoenne (6) v. § 32. 2); lond V. $1,10,14$ etc. (15), (v. $\S \S 144,145$ ); mondo (sportas, cophinos) VIII. 8, 19; monn, aldor- I. 23, III. 1, 27 etc. (67), (v. § 166. I); ondo (tremor) XVI. 8; ondget XII. 33, ondsworade XIII. 2 etc. (v. § 74. VIII); stonde III. 24, 25 etc. (14), (v. § 129. I.); Jonne I. 14, 32 etc. Loan-words: heafud-ponnes XV. 22; plontað Pref. 2.5.

The conjunction WS. and is expressed regularly by the sign 7 , with one exception viz. end (atque) Pref. 1. 9. ef. John XXI. 19 and.

5) Before a guttural nasal: ahongene XVI. 6; long VII. 6, IX. 21 etc. (9); strongre I. 7, III. 27 ; Joncungo VIII. 6, XIV. 23; tuongas I. 7, VI. 9; wlonca X. 25, XII. 41, wlonga Pref. 4 XXXII (v. § 99. 2).

Loan-word: song (stratum) XIV. 15 (v. H. p. 5. ef. $\$ 144$ I. Note).

6) Lengthening of $o(=$ WGmc. $a)$ before the consonant groups $n d, n g$ is marked by an accent in the following instances: hônd XI. 31, XIV. 41; lônd I. 5, 28, 38, VI. 55; lônga V. 10, lôngiga (taedere) XIV. 33. Lengthening before simple $n$ : ôn Pref. 3. X. (Sw. H. E. S. §§ 384, 394. ef. § 38. 4).

$a$.

83. $a$ from older $a$ appears in conformity to the rules given in $\mathrm{S} . \S 49$. This $a$ is occasionally written $a e$, and $e$ (cf. de for $\hat{a} \S 42$ ).

1) $a$ before a simple consonant, or where the consonant has only been doubled by the scribe, occurs in the following forms of the $1^{\text {st }}$ and $3^{\text {rd }}$ Pers. sg. of the Pret. Indic. of the strong verbs of classes IV. and V. (v. §§ 127. II, 128. II): boed, boedd I. 35, 40, X. 17 etc. (8); forbraec V. 4, VI. 41, VIII. 19; cucঠ II. 27, IV. 35, V. 19, IX. 24 etc. (9), (beside cueð (19), v. (3) below, and cuoed (144) v. § 33); agøf XII. 1, XV. 37 (beside -geaf XV. 15, -gecef X. 4, v. § 29); ongat, -goett II. 8, XV. 45, Pref. 4. XXVII (beside ongeat V. 30); gesaet, -satt XI. 2, 7 etc. (9); spraec, spraecc II. 2, IV. 33, 34, VIII. 32, XIV. 31; woes I. 4, 7 etc. (153), noes II. 27 (was XVI. 2). In certain Pres. forms of the verb fara: foerende I. 16, 35 (16), fares XVI. 7, fare wre IV. 35; in the Pret. Pres. verb mag III. 23, 25, 26 etc (18), 
(v. § 137. 7); in the Past Part. Ab. VI of-sloggen IX. 21, and in the Pres. forms onsacco ic (negabo) XIV.31, onsacce (deneget) VIII. 34 (v. Brown $\S 2$ b.).

The forms with ae are: faerende X. 17; ongaet VIII. 17; laeg II. 4; maeg II. 7, maege XIV. 2; -saet IX. 35, X. 46.

The remaining examples other than strong verbs are: $x t$, ad- I. 16, VI. 55, XV. 41, XVI. 14 etc. (26), (v. § 95); aðelı XVI. 1 (S. $\$ 50.2$ ), aeðil-wald Pref. 1 heading; bacc VIII. 33, brecg XIII. 16; barlice XIV. 2, baersynnigum II. 16 etc. (3), (v. $\S 27.1$ ); -dœg II. 27, VI. 21, XI. 12, XIV. 30 etc. (17), (v. § 142 doeg, doege v. $\S \S 50.1,165)$; faeder VII. 10, IX. 21 etc. (6), (v. $\S 163$, fader V. 40 , v. $\$ 1.3$ ); fret IV. 21 , XIV. 3 etc. (5); got I. 33; glcedd-môd X. 49, glcednise IV. 16; høfet, hafes II. 10, III. 30 , IV. 25 etc. (14), (v. § 136. 1. cf. Brown § 2 a); hrceðe IV. 5,17 (beside hraðe I. 28, v. S. § 315, anm. 2); huces XII. 16, 23, XV. 24 ; hucet, hucedt II. 7, 8, 24, X. 36,38 etc. (54), (v. \$§ 95, 185); latmest, hloet- IX. 35, X. 31, XII. 6, 22 ete. (6), (v. \$§ 101. 1, 175. II, 177. S. $\S 40$, anm. 2); plagede VI. 22 (cf. S. $\$ 416$, anm. 6); onsac, onsacc (adj.) XIV. 30, 72; onsucerede, -sucerde XII. 34, XIV. 48 (beside onsurade v. § 1. 3); Jaccilla (lucerna) IV. 21 (cf. L. § 3. 2); joes I. 7, III. 24 etc.; joct (Pron.) IV. 4, 30 etc. (18), expressed by the abbreviation $\$$ (109), as a Conj. always written $\$$ (38), (cf. dotte, pie below); warlice XIV. 44.

Loan-words: placcum (plateis) VI. 56; and possibly Jaccilla (v. above), if it is a byform of facele.

The forms with ae are: aedeawde XVI. 9; daeg IV. 27, IX. 31 etc. (6); faeder I. 20, IX. 24 etc. (8); faet XI. 16; hatfes VII. 16.

2) Before consonant groups: after- I. 7, II. 1, IV. 17 etc., (afier Pref. 1. 15); deersto VIII. 15 (2), XIV. 12, Pref. 3. XXIV (v. $\$ 156$. III.); foesta (ieiunare) II. 19, 20, VIII. 3 etc. (5); fest, sod-fast, fostnung XV. 44, II. 17, V. 5, XII. 14, 32, Pref. 2, 5, fastern IX, 29, Pref. 1. 12, 5. 16; gefragn VIII. 23, 27, IX. 21, grfregndon IV. 10, XIV. 61, XV. 2 (beside gefregn v. (3) below, and gefraign v. §63.2); ongagn XII. 41, togcegnas IV. 35, V. 2 (beside -geaegn v. $\S 28$ ); haebbe IX. 43, 45, 47 etc. (13), hafde I. 22 , II. 25 etc. (24), (v. § 136. 1); hraeglo XIV. 63, XV. 17, 38; magden V. 41, 42 etc. (6), (beside maden (4) § 43. 3); magne IX. 1, XIII. 25, 26; meslen (aes) VI. 8, XII. 41 (v. § 68. 2); sagde IV. 34 etc. (20), (v. § 136. 2), sagdnisum XII. 33; scaftes 
X. 6 (beside sceafte, sceceftes v. § 29. 3, ef. L. §§ 3. 2, 13, 2a); tatte II. 10, in all other instances expressed by the abbreviation pte I. 37, 45 etc. (Conj. 148 Pron. (quod) 18. v. § 97); waestm IV. 7, 8, 19, 20 etc. (8); wcetre I. 8,10 etc. (5), (v. § 78. II). For the form gescette Pref. 3. XI without $i$-umlaut (beside sette $\S 23$. 1) v. S. $\S 401.2$.

The forms with ae are: aefter XV. 20, Pref. 1. 1, aefterra XII. 31; gefraegn XV. 4, 44; haefd Pref. 1. 16, haefde XIV. 3, ongaegn XV. 39 ; maegden VII. 30; maegne XII. 30; saegdon XIV. 4, asaegd Pref. 5. XLIV.

Note. gefrceppegedon (reuerebuntur) XII. 6. Rushw. gefropegadun is an obscure word. B-T. gives only one other reference for its occurrence. Mt. Kemble Lind. XII. 10 gefropgedon (accusarent).

3) $e$ for $a$ occurs in the following instances cued II. 17, 24 etc. (19), (v. § 107); gefregn V. 9, gefregndon I. 27, ic fregna XI. 29, fregnende Pref. 5. XL, 4. XXXVII, gefregna Pref. 2. 4 (v. § 134. 3, beside -fraign v. § 63. 2); gers IV. 28, VI. 39 (grasum IV. 32. v. § 1. 4, and § 85. 3); hueðer III. 2, IV. 21, V. 40, XIV. 19 (beside huoeðer v. $§ 33.1$ ); seternes dag Pref. 5.16 (v. S. § 50, anm. 2); 內ene VIII. 23 etc. (v. § 2. 3. S. § 65. 2).

The $e$ in feder (patri) VII. 10, 11, 12 is apparently due to $i$-umlaut (v. L. § 3.2. p. 5).

Beside the North. Subj. form walle XIV. 12, 36 etc. (12) for WS. wille (cf. L. §3.2, anm. p. 5), occurs a form welle IV. 30 , V. 36, X. 11 (v. § 139).

e.

84. Lindelöf's observations on the occurence of $e(=\mathrm{Gmc}$. $e$ ) in the Durham Ritual are equally true if applied to its occurence in St. Mark. It occurs frequently unchanged, as in WS. It also occurs where in WS. it would have become ie through the influence of a preceding palatal. On the other hand its occurence is limited to a greater extent than in WS. by the action of the $u$ - and $o$-umlaut, and by the influence of a preceding $n$.

1) Examples of $e$ in various forms of strong verbs of Classes III, IV, V are: ber II. 9, beres XIV. 13 (for the absence of $i$-uml. in the $2^{\text {nd }}$ and $3^{\text {rd }}$ Pers. sg. Pres. Indic. v. S. $§ 371$ anm.), berendum XIII. 17; ic cueðo II. 11, III. 28, cueðendo III. 11 etc. (3), acueðen Pref. 1. 15 (v. § 128. I-IV); -delfad IV. 19 
( $d$ written for $\partial$ ); ettes II. 16, XI. 14, pte he aet $t$ ett II. 16, ett is apparently the contracted form of eted (v. §107), (altces XIV. 18), ellanne VI. 37 (beside eata v. $\$ 16.2$ b), other Pres. forms (4), (v. 128. I); ic forgefo XV. 9, other Pres. forms (4), -gefen II. 9 etc. (4); geldas XII. 17 (gyld (sb.) Pref. 4 . XXXVIII. v. §30); forgelne VIII. 14, X. 21; help IX. 22, 24; gelegen I. 30; sell (sb.) I.32. onsetnum VI. 5, VIII. 23; spreca, sprecca I. 34, IX. 39, XII. I etc. and other Pres. forms (18), (v. § 128. I, beside spracend (2) v. § 5); forslele X. 19; -gesuelta XIV. 31, XV. 37, 39 (v. $\S 126$. I); wes (2 ${ }^{\text {nt }}$ sg. Imp.) IV. 39 (beside was (2) v. § 5). For the forms with $u$-, o-uml. beara, cweoða etc. v. $\$ 16.2$, and with the influence of preceding $w$. cuoeð $a$ v. $\S 32$.

2) In words other than strong verbs: gebedd (orationis) XI. 17, XII. 40; efne II. 2, III. 20 etc.; fellera I. 6; feltun VII. 19 (v. S. § 231. 3); gef (Conj.) XII. 19 (beside gif 1II. 1 etc. (37) ef. Brown $\S 16$ a. p. 32); forgefnisse I. 4, II. 10, III. 29, Pref. 4. XXXI etc. (6); ondget XII. 33; derne legero VII. 21, VIII. 38, X. 11, mec, meh I. 7, 17, 40 etc. (38), (v. §181. I); recone, hrecone I. 29, V. 2, 29 etc. (11), (v. § 101); sedlo Pref. 4. XXXIII, setla XIl. 39 (beside seatlas v. § 16.1); bismerayad X. 34, XV. 20, 31 (beside smiriane $\S 14.2$ ), bismerlice VII. 9 ; bispell IV.10, $13,30,34$ etc. (13), (v. § 145. I), godspelles I. $1,14,15$ etc. (9); slefi I. 3, 11, 20, V. 7 ete. (13), (v. § 146. I, III, IV); telgo IV. 32, XI. 8, XIII. 28; tintergo (gehennem) IX. 43, 45, 47; ðec, Jeh I. 11, IX. 43 etc. (17), (v. § 181. II); Jegnas II. 18, 23 Pref. 4. XXXV etc. (54), (v. $\$ 143$. I, II, III beside ठcegnum v. § 5); des (hic) II. 7, IV. 41 etc. (6), (v. § 183); wege I. 2 (beside woeg v. $\$ 32.1$, weeg v. $\$ 5$ ); wel III. 4, VII. 6 etc. (6), (beside woel v. §32. 1); wer VI. 20, X. 2, 12.

Loan-words: tempel XI. 15, 16, XIII. 1 ete. (14), (v. § 144. I, II, III); senepis Pref. 3, XII (sinapis IV. 31), ef. Brown $\$ 22$, p. 39: "in senepes ist das $e(=$ Rom. $e$ ) 'dunkel' (Pog. $§ 120)$ ".

The $e$ of the old reduplicating - syllable appears in heht I. 44 , VI. 27 etc. (10), (v. $\$ 130$. II).

Note. 'The word felle in mid felle reade hrogie, yces fellereades (purpura) XV. 17, 20 is obscure. Cf. Lind. Luke XVI. 19, Lind. and Rushw. John XIX. 2.

8. In a few cases Gmc. $e$ occurs as $w$ : gehcela (latere) VII. 24; pleges (sb.) Pref. 3. XVII; sprceccend IV. 34, VIII. 32 (beside sprecend (9)); ذcegnum XIV. 32 (beside ठegnum etc. (54)); 
ðarscende V. 5 (v. S. § 79, anm. 2, geðcearsca v. § 13.2); waeg Pref. 4. XXIX (beside wege v. § 4.2, woeg (16) v. § 32. 1); wcelig X. 25 (wealigo XII. 41, v. § 16); was (esto) V. 34, X. 49 (beside wes IV. 39); wuracce (torqueas) V. 7. For waro, warana v. § 36.

$i$.

86. $i=$ Gmc. $i$ from $e+$ Nasal + Cons.: (v. S. § 54) occurs regularly:

1) Before $m+$ Cons.: gelimpa X. 32: timber XIII. 1 etc. (6), (v. § 76. II).

2) Before $n+$ Cons.: In Pres. forms of strong verbs of Ab. III. Cl. I. (v. § 126. I): gebinda V. 3, XI. 2 etc. (5); blinn VII. 27; drinca X. 38, XV. 23 etc. (9); onfindes XI. 2; onginnad XIII. 4 etc. (5); scrinceð IX. 18; gesinga XIV. 72; suingeð X, 34; Jringende V. 31 . In the substantive verb: sindon V.9, XIV. 36 , sint IX. 1,3 etc. (23), (v. § 138. v. Kluge, P. G. § 36.6, p. 372), In other words: blind VIII. 17, 23, X. 49 etc. (7), (v. §§ 169, 173. III), fore-geblind VI. 52; drinca (sb.) IX. 42, XV. 36; fingeras VII. 33; gesuinged XIII. 9; intinges XV. 26; tintergo IX. 43, 45, 47 (cf. Brown, § $26 \mathrm{a}$, p. 43); ting II. 21, V. 26, VII. 4 etc. (7); geðringdon V. 24; wind IV. 37, 39, 41 etc. (8); winstra X. 40 (wynstra จ. § 27. 3); wintrum V. 25, 42, XIII. 18 (v. § 153. II).

3) $i=$ WGmc. $e$ before Nasals (v. S. § 69) in: nim II. 9, 11, nimmeð II. 21 (beside nioma v. § 17).

4) Lengthening of $i$ before $n d$ is marked by an accent in wudu bînde I. 6 , blind X. 46.

87. $i=$ Gmc. $i$ from $e$ before an original $i$ or $j$ occurs in the following instances:

1) In the Pres. forms of the strong verbs WS. biddan, licgan, siltan (v. $\S 128$. I): bidda V. 17, 18, VI. 46 etc. (16); licgende II. 4, V. 40 etc. (6); sitta X. 40, XII. 39 etc. (13).

2) Other words: Billfrid Pref. 1. heading; fore-cuido Pref. 1. heading, 2. 7; gristbitteঠ IX. 18; micel XIV. 15, XVI. 4 etc. (25), (v. § 78. I. Brown § 41. p. 55 gives this word under $i$-uml. of $u$, "nach Kluge, Engl. Stud. XIII. 508"); niddum VI. 47, IX. 36, XIII. 35, middan- VIII. 36, XIV. 9, XVI. 15. the form medo (medios) VII. 31 is apparently a scribal error, due to confusion with the Latin. Rushw. has middum; milsande I. 41, V.19, VI. 34, VIII. 2, X. 47, 48 (v. § 96. 4); mitta (modio) IV. 21, Pref. 3. XII, gemitte VII. 30 , XI. 13, XIV. 37, 40; scillingum XIV. 5; 
sibb V. 34, IX. 50; sihخo IX. 9; wiht VI. 49; wilde I. 13, Pref. 1. 12 ; willo (sb.) III. 35, Pref. 3. X; willo (vb.) I. 41, VI. 25 etc. (8), (v. § 139. For the pl. Pres. form WS. willad occurs wallad X. 35 , XV. 9 etc. (7), v. S. $\S 428)$.

The $i$ in cild IX. 21, X.13, Pref. 4. XXXI is of uncertain origin (cf. Brown $\S 27 \mathrm{~b}$ ). The origin of the suffix in earliprico (auriculas) VII. 33, earelipprica XIV. 47 is also uncertain (v. Kluge, Nom. Stamm. III. $\S 68$ b).

8. $i=$ original Idg. $i$ appears

1) in Pret. forms of st. vbs. Cl. I. (v. § 124. III, IV) fordrife, -drifen V. 10, 13, 40 etc. (8); ge-grippen I. 31; gehrinon VI. 56 etc. (3); arisen XIV. 28, XVI. 2 etc. (4), arisse (resurrexisse) XVI. 14 may be Pret. Subj., or possibly Pres. Subj. with doubling of the following consonant to mark a long vowel (v. $\S 38$. 3, Sw. H. E. S. § 391); -stigon III. 22, IV. 7, X. 32 etc. (5); awritten I. 2, VII. 6 ete. (9); and in the Pret. Pres. verb wita IV. 11, V. 33, 43 etc. (14), (v. $\S 137$, beside gevuta v. $\S 37$ ).

2) The remaining examples are: bifgedon ${ }^{1}$ XIV. 5 ; cuic IX. 49, XII. 33; fordrifnise Pref. 2. VII; fiscas VI. 38, 41, 43 etc. (7), fisceras I. 16, 17, Pref. 2. III; Billfrið, Eadfrið Pref. 1. heading; hider XI. 3; him I, 5, 10, 13 etc., hine I. 12, 20, 26 etc., hir V, 33, 34 etc., his I. 3.6 etc., hit IX. 10 (v. § 181. III. hîs III. 21 v. § 38. 4); hlingendum VI. 22, XVI. 14, II. 15 (gelionede v. $\S 17.1$ ); hwider VI. 10, 56, XIV. 12,14 ; lifgiende Pref. 1. heading ete, (4), (v. § 136); niguða Pref. 5. XL; niðria IV. 1, 37, 38, IX. 12, XIV. 64, XVI. 16, Pref. 3. XX, 4. XXXII; ripes (sb.) IV. 29 (rip v. Sievers P. B. B. X. 506); risnelic IX. 11 (v. § 89); scip I. 19, 20 etc. (19), (v. § 103); smið VI. 3, Pref. 3. XV; fromslittnise XIII. 14, -slitnessa II. 21 (B-T. gives "slitness (slit-?)"); spittes X. 34, XIV. 65; esuicnis VII. 21; tider VI. 33; Iwiggo IV. 32, XIII. 18; wincise X. 19, XIV. 63; wiঠ III. 6, VI. 10 etc.; wiðer- III. 23, 26, VI. 48, VIII. 33, XIII. 22; megnlitlice Pref. 4. XXX; writ (sb.) XIl. 10, 24, XIV. 49, XV. 28.

Loan-words: biscobas XV. 11, Pref. 2. 2; disc VI. 25, 27, VII. 4 etc. (6); discipul Pref. 1. 2; titul XV. 26.

1 v. Skeat's Preface. p. XXVIII. "For an example of error, observe the word bifgedon (they trembled) as a translation of fremebant in XIV. 5; the worthy glossator was clearly thinking of tremebant". 
0 . words:

8. $o$ ( $=$ WGmc. $o$ ) remains unaltered in the following

1) In the Past Part. of strong verbs of Classes II, III, IV: $b_{0}$ den XIII. 10, XIV. 9; geboren II. 3, XIV. 21, XV. 43; gebrocen XIV. 3 (v. C.N. 144 "gebrecen alt. to gebrocen"); gecorenum XIII. 20, 22, 27; agotten II. 22, XIV. 24; tostrogden III. 25, XIII. 2, XIV. 27; aworden I. 9, IV. 22, 35 etc. (23); toworpen, for- III. 26, IX. 38, XIII. 2 (v. $\S 126$. IV). The $o$ in the adjectivally used Pres. Part. Jorfendum X. 21, XII. 42, XIV.5, 7, is apparently from the Pret. ठorfte (cf. § 12.4).

2) In other words: bod XII. 28, 29, 30, 31 etc. (15), (v. $\S 145$. I, II), boderes Pref. 3. XVI; bodiga, bodade I. 45, III. 14, etc. (18), (v. § 134), forebodung Pref. 5. XLVI; bolstâre IV. 38; cofa XI. 17 (not côfa v. Sievers, P. B. B. X. p. 497); gecoreniso Pref. 2. 1; corn IV. 31. Pref. 3. XII ; cosiung IV. 17, XIII. 19, 24, XIV, 38, costendo VIII. 11, IX. 49, X. 2, XII. 15; dohter V. 23, 34 etc. (10), (v. § 163.4); dor XI. 4, XII. 41, XIII. 34; duolas XII. 24, 27 (v. C. $\$ 42$, p. 69); fola XI. 2, 4, 5, 7; folc VI. 45, 53 etc.; the vowel in fore-, for-, befora, forma, onfora is seldom written out in the Ms. (จ. Skeat's Pref. p. XXVIII), for ठor V, 35, VI. 51 etc., and fortmest X, 31 etc. are always contracted; forhlo t frohto (adj.) IV.40, forhtade, froht- V. 33, XIV. 33, XVI. 6, Pref. 2. IV (v. § 85); god, godspell I. 14, 15, II. 7, 12, Pref. 1. 1, 7, 10 etc. (v. § 103); un-hogo VII. 18; gehornadon (affecerunt) XII. 4; gehoroga XIV. 65; lopestro I. 6; losige I. 24, III. 4, 6, VIII. 3 etc. (11) (v. § 135 etc. lôsad Pref. 2. 1, v. § 38. 5), losuist VIII. 36, XIV. 4 (lôsuist IV. 19); hlott (sortem) XV. 24; morgen XV. 1, XVI. 9; morðor- VII. 21, XV. 7; ofer III. 5, 8, 25 etc.; oft III. 10, V. 4, VI. 56, VII. 3; ge-opnadon II. 4; posa (peram) VI. 8; smolt VI. 47, (smyltnis v. § 27. 1); snotorlice XII. 34; geðolade V. 26, VIII. 31, IX. 12 (2), 19, XIII. 13, XIV. 34; Jorn IV. 7 (2), 18, 28; wolcen IX. 7 (2), XIII. 26, XIV. 62; word I. 45, II. $2, \mathrm{X}, 24$ etc. (31), (woerdum XV. 3 is a scribal error, perhaps due to the fact that the group oe is common after $w$ ); worhte VI. 21, X. 6, XI. 17, XIV. 58 (2), XV. 1, 7; worn V. 11.13.

WS. wolde, woldon appears as walde, waldon III. 13, VI. 19 etc. (11), (v. § 139). 
Loan-words: apostolas VI. 30; ole VI. 13 (with i-uml. oelebeama v. $\S 26$ ); portas VI. 6 ; torr XII. 1 (o from Lat. $u$ v. Pog. $\S \S 152,156,159$ ); stolun (stolis) XII. 38, XVI. 5 (stôle. Pog. $\S \S 147,150$ ); holdum (tribunis) VI. 21 (v. Klnge, P. G. p. 786, and Bout. p. 349). Corresponding to WS. cuppe appears the form copp IX. 41, XV. 36.

3) Lengthening of $o$ before the consonant group $r d$ is marked by an accent in wôrd XIV. 13 (Sw. H. E. S. § 395). The accents in lossad Pref. 2.1, lôswist IV. 19 are apparently mere errors (v. § 38.5).

Note. For $o$ in ebolsas II. i, III. 28, 29, XV. 29 (2), ebolsungas III. 28, VII. 22, XIV. 64, Pref. 3. X, v. S. $\$ 43$, anm. 4. L. $\$ 7$, anm.; $o$ for $u$ in the sb. and adj. inflectional ending -um occurs in wilgom VI. 15, ilcom VII. 36 , XIV. 69; switrom XIV. 62, in the case of the last two words the final $m$ is not written out in the MS.

$u$.

8 10. $u=$ WGmc. $u$, and $u$ from WGmc. $o$ before nasals (v. S. § 29), or in certain cases where preceded or followed by a labial (v. Sw. H. E. S. § 423) occurs regularly as in WS. (For $w u$ from wio $\mathrm{v}$ § 37.)

1) In the Pret. plur. of st. vbs. of Cl. II, and in the Pret. plur., and Past Part. of st. vbs. of Cl. III (v. §§ 125. III, 126. III): forbudun IX. 38; gebugun XI. 8; bulgon XIV. 4; gebundon XV. 1, gehunden V. 4, VII. 35, IX. 42, XI. 24, XV. 6, 7; gecure (Subj. sg.) XIII. 20; -dulfon IV. 7; gedruncon XIV. 23; -fundon I. 37, XI. 4, XIV. 55, (Subj. sg.) Pref. 1. 9; flugon V. 14, XIV. 50, XVI. 8: -frugnun VII. 5, 17, IX. 10, 11, 14, 28, 33 etc. (13); onguninon II. 23, V. 17, VI. 55, XIV. 19, XV. 18 etc. (8); hlulon III. 11; Jurscon XII. 3, 5; ge uurnun VI. 33, 55, IX. 15 (v. (3) helow); -nurdon VI. 56, Pref. 1. 16; genurpon XII. 8, 41, XIV. 46, (Subj. sg.) VII. 26. In the Pres. forms of the Pret. Pres. verb WS. cunnun: -cumna IV. 13 etc. (5), (v. § 137. 2). The weak grade vowel of $\mathrm{Cl}$. III. appears in the present stem forms of the st. vb. WS. spurnan: ondspurnas IX. 42,43 etc. (6), (v. 126. I). For genumen II. 20, IV. 25, XVI. 19. v. S. § 70. For cumad III. 19, VIII. 31, X. 14, XV. 21 (beside cymað etc. § 27) v. L. p. 89 , anm. 
2) Other words: burg- I. 33, II. 1, burig XI. 2, burug I.21, $\mathrm{X}, 46$; culfre I. 10, XI. 15; -cund Pref. 1. 1, 6, 2. 3; cunnung Pref. 1. 2, 5. XLII; acunnad I. 13 etc. (4), (v. §§ 115. 3, 134, 2); cursendo XV. 17; dumb VII. 32, 37, IX. 17, 25, Pref. 3. XXII, IV. 39 (v. § 92); duru I. 33, II. 2, XIII. 29, XV. 46, XVI. 3; fuglas IV. 32; full IV. 28, VI. 43 etc. (5), fuluiht I. 4, VI. 14, VII. 8, X. 38, 39 etc. (14), gefulwas I. 8, VII. 4 etc. (11), (v. \$§ 134. 1, 135); fruma X. 6, XIII. 8, 19 (fruma I. 1, Pref. 1. 4, 7, 8, v. $\S 38.5$ ); -guma II. 19 (2), 20; hundradum VI. 21 margin, 37, 40, X. 30, XIV. 5 (v. § 178); hundum (canibus) VII. 27; hungro XIII. 8; hunig I. 6; lufu Pref. 1. 15, 16, lufade X. 21, XII. 30, 31, 33 (2); lust- IV. 19, VI. 20, XII. 37, lustum IV. 28, VII. 12 (v. § 72); scua IV. 32 ; sum IV. 4, 5, 7, VII. 1, 2 etc. (16), (v. §§ 103, 186); sumer XIII. 28; sunu I. 1, 11, II. 10 ete. (49), (v. § 153); sundrig VI. 31,32 , VII. 33, XIV. 66 (beside syndrige v. $\$ 27$ ); -sunigo II. 15 (beside synnig v. § 27); sunna- I. 32, IV. 6 etc. (10), (v. § 158. I); geðungennise Pref. 2. 6; ðunres III. 17; ðus X. 43 etc. (11); trumlice Pref. 5. XLVI, wyrtruma IV. 6, 27, XI. 20 (beside wyrtryma v. § 27); tunga VII. 33, 35; -ufa IV. 38, VIII. 6, XV. 38, XVI. 5, Pref. 3. XIX (v. S. § 55); under II. 26, IV. 21 etc.; upp-

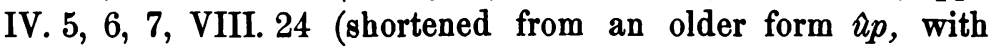
doubling of the $p$ on analogy of uppan, v. Sw. H. E. S. § 399); wuldre VIII. 38, X. 37, XIII. 26; wunigende I. 10, IV. 32, VI. 10, genuna (adj.) X. 1, XV.6; genundadon XII. 4; wundrum VII. 8, XII. 11, Pref. 5. XLV (v. § 145. III), wundrande I. 27, VI. 2, X. 26 etc. (15), (v. §§ 115. 3, 134).

Loan-words: muntum XIII. 14 (v. S. § 70); tunucum VI. 9; luh (fretum) V. 1, 21, VI. 45, VIII. 13 (v. B-T. Welsh llwch).

3) Lengthening of $u$ before consonant groups is marked by doubling of the vowel in fulvihta VII. 4; suundorlice XIII. 3 ; also in Jerhwurnon (percurrentes) VI. 55, ge- VI. 33, IX. 15, the sign $w$ being an error caused by the fact that the scribe was accustomed to write either $w$ or $u$ indifferently in the case of the semi-vowel (v. $\S 80$ ). Lengthening of $u$ in the prefix un- is denoted in unclaene I. 33, un-eaðalice Pref. 4. XXXII (v. Sw. H. E.S. § 385).

Note. For WS. Jurh occurs always Jerh II. 23, XIV.21, 58 etc. (v. S. $\S 56$, anm. 1 ; L. § 11 . III. p. 19).

The form numenne (uulsione) Pref. 2. VIII is not clear. Possibly it is for nimenne from a Nom. *nimen, a verbal abstract in -en from the st. 
vb. niman. The word in the corresponding passage Luke Pref. V. XIX is nimung. A still more difficult word is unful (insulsum) IX. 50. Bouterwek's explanation (Introd. p. CIII) is untenable, being based on an erroneous reading "gifunful", whdreas gif is really a separate word, simply the conjunction gif, part of the gloss to the preceding quodsi. Can unful be miswritten for unsall? In the MS. the $f$ only differs from $s$ by an additional cross stroke, and $a$ may be written with an open top, and so resemble $u$. Further, a final consonant is sometimes dropped cf. tuoel, for tuoelf Pref. 2. X, dum for dumb IV. 39, senden for sendend Pref. 5 XLI etc. (v. $\S 96)$.

\section{The Breakings.}

811. $a$ before $r+$ Cons. remains unbroken in a few instances, but in the majority of cases it is broken to $e a$ as in WS. The precise numbers are as follows:

1) a remains unbroken in: arg VIII. 38; gedarste XII. 34; ned-ðarf II. 17, XI. 3; -ward I. 32, VI. 2, XIV. 17, XV. 33 (geweard II. 23); -warp XII. 41, XIV. 52, XVI. 9 (-woearp X. 50, with influence of $w$ ). Loan-words: carcern VI. 17, 27; carre XV. 46.

The form geonduarde XII. 28, XV. 12 (beside onduearde $31)$ is probably due to the influence of $w($ v. L. $\S 9 . \mathrm{I} \mathrm{b})$, or to want of stress (ef. S. $§ 43.2$ ).

Breaking does not occur before $r+$ Cons. resulting from metathesis (v. S. § 79, anm. 2): arn V. 2, 6, X. 17, XV. 36, Pref. 4. XXVIII; gers IV. 28, VI. 39 (with $e$ for $a$ v. \& 3. 3). In dom-êrn XV.16, $e$ is weakened from $a$ (v. S. $\S 43.3$ ), the accent denoting later lengthening before $r n$ (cf. Sw. H. E. S. $\S 395$ berérn).

2) $a$ before $r+$ Cons. is broken to ea in: -cearf VI. 16, 27, IX. 43, 45, XIV. 47; eardes XIII. 27; earnade Pref. 2. 1; -geard XII. 1, 2, 8, 9, XIV. 35; gearuu XIV. 38, -gearuas I. 2, 3 etc. (16), (v. \$§ 134, 135); heardnisse X. 5; heurm XV. 32; -neard VII. 23, XII. 7, Pref. 1. heading, 4, 5. XL (innueeard VII. 21. v. C. N. 143. "innuaeard alt. to innueeard"), to- X. 30, 32, ufa- XV. 38, wiðer- I. 13, III. 23, 26 (v. C. N. 142 "wiðerworde alt. to wiðerwearde"); ondueardus XI. 29, 30 etc. (31), (v. § 134. 4). beside -uaearde VI. 37, -warde XII. 28, XV. 12); -wearp X. 50 (-woearp X. 50); -wearঠ II. 23 (beside -warp 3 -ward 2. v. $\S 11.1$ above). 
3) $o$ for $e a$ in the unstressed second member of compounds, and preceded by a labial (v. S. $\S \S 43.2,51$ ) occurs in: doruorde XIII. 34; nioðuord XV. 38 (beside inn-, 10-, ufa-weard 5), wiðer-word III. 23, IV. 15, VI. 48, VIII. 33 (beside -wearda 3). The vowel is still further weakened in: hlaferd XII. 9, XIII. 35, hlafurd II. 28 (v. § 75).

4) $a$ for ea occurs in: erfeward XII. 7 (beside erfe-weardnise XII. 7); 10-wardnum Pref. 5. XLII (beside -neard 2).

万aerfen XII. 43 (= ذarfend beside dorfend (4), v. § 9. 1) has apparently the $a$-ablaut, possibly influenced by the Pres. sg. ic ঠearf, or by the sb. WS. ঠearfa (cf. S. § 422. 6).

warmde XIV. 54, warmigende XIV. 67 cf. L. § 3. anm. p. 5. "Einigemal erscheint $\alpha$ in wörtern, wo man ea (oder $a$ ) erwarten sollte" (cf. farme, Jarscende § 13).

Setting aside the instances quoted under 3) and 4), $a$ occurs unbroken only in sixteen instances; of those, three are loan-words, and ten are cases where the vowel is preceded by $w$. Breaking to $e a$ occurs in seventy-eight instances and may therefore be regarded as the rule.

812. In the case of $a$ before $l+$ Cons., St. Mark corresponds precisely to the Dur. Rit. (v. L. § 9. I. 2). The only word in which breaking occurs is sealla (v. S. § 158.2). Lindelöf suggests that the $e a$ may be due to $o$-umlaut and not breaking.

1) $a$ remains unbroken in: alde II. 21. (2), 22, Pref. 2. VII, aldor- I. 44, II. 26 etc. (16), (aldra (sb.) v. § 24); Aldred Pref. 1. heading; all I. 5, 22, 33, IX. 35, XII. 22, XIV. 48 etc.; ballice XV. 43 (= buldlice S. § 198. 3); -cualmniss XV. 7; dalf XII. 1; -fald X. 46 (2), XII.44, Pref. 2. IX, -fallice Pref.4. XXXII (= faldlice S. § 198. 3); -fallende XIII. 25 (v. C.N. 143 "feollende alt. to fallende"), falletande V. 5 (v. § 104. 2); haldanne III. 21 etc. (15), (v. § 130. I.); halfe I. 45, VI. 23; gehalp V. 26; hall IX. 45; salde III. 15, 19 etc. (37), (sealde XIV. 22), saldend XIV. 44 (v. §§ 115. 2, 132. III, 133. III); salt IX. 50 (3); Edilwald Pref. 1. heading.

Loan-words: salmes Pref. 5. XL. In asalde Pref. 4. XXXV. the $d$ is inorganic (v. $\S 96$ ).

Lengthening of $a$ before the group $l d$ is marked by an accent in: sáld VIII. 12, sâlde XIII. 34. 
2) $a$ is loroken to ea in: sealla V. 43, XIV. 5, 11, 55 etc. (7), seallane XII. 14 (sellanne X. 40, v. § 23. 1), -seallas XIII.9, (sellad XIII. 22, XV. 23), sealde XIV. 22.

813. $e$ before $r+$ Cons. appears as $e o$ and $e a$, and very rarely as $a$ and $a$. (For the interchange of $e o$ and $e a$ in North. v. S. § 150. 3).

1) $e$ is broken to $e o$ in: ceorl XII. 25, margin (2), cort)II. 3,9 etc. (25), (v. $\S 158$, beside earðu v. (2) below); heorta VII. 21, XII. 30, 33 (beside hearto 8); leornade II. 25, XII. 10, 26, XIII. 28; steorras XIII. 25.

The old reduplicated Pret. leor $t=$ WS. lêt (v. S. § 394) appears regularly: -leort I. 20, 31 etc. (21), (v. § 130. II).

2) $e$ is broken to $e a$ in: brearde (summum) XIII. 27 (cf. S. § 79, anm. 2); earठu IV. 31, VI. 53 (beside eorðo 25); fearre V. 6 etc. (9), (v. $\S 176.6$ ); hearto II. 8 etc. (8), (beside heorta (3) v. §§ 158, 159); meard IX. 41, Pref. 2. 5, 3. XVII; -ðearsca XIV. 65, XV. 15 (darscende V. 5).

The oid reduplicated Pret. of the st. vb. WS. (on)-drâkdan occurs without exception as ondreard V. 33, VI. 20 etc. (11), (v. § 130. II; S. § 394).

3) $a$ for WS. eo occurs in farma (cenam) VI. 21, XII. 39 due perhaps to the labial influence of $f$ on ea for WS. eo (cf. waras $=$ WS. weras v. $\S 36$, and fattro beside feotrum v. $\$ 16$ ).

For the North. form ard I. 11, 24 etc. (8), (v. § 138) beside Ws. earl v. Sw. H. E. S. § 442 .

a occurs in farme Pref. 5. XLIV; jarscende V. 5 (beside -dearsca 2).

Note. The word ferlino (portenta) XIIl. 22 is not clear. Rushw. has fortina. In Mt. XXIV. 24 the Lind. glosses prodigia by forclaceno. Perhaps ferlino is a corruption of this very word. The initial letter in the MS. may possibly be intended for a $p$ and not $f$. The loop is brqught further down than in the $f$ thus $p$ and not, as usual, $p$, but the horizontal stroke is more prolonged than it generally is in $p(p)$.

Another obscure word is celmerimonnum I. 20 (Luke XV. 19, John X. 12, 13 Lind. and Kushw.). For Mr. Bradley's suggestion that it may be derived from "a late Latin col(l)imberlus, a possible variant of collibertus" v. The Academy, Oct. 31. 1891, p. 385.

814. WGmc. $i$ (from Gmc. $e$ ) before $r+$ Cons. (v. S. $\$ \$ 79$. $2,100)$ appears as $i o$ and $i$. 
1) io occurs in: giornede I. 40, IV. 19, X. 46; hiorde VI. 34, XIV. 27; -iornende IV. 5, V. 25, IX. 25, XIV. 13, Pref. 3. XIV; riordung (refectio) XIV. 14, geriordade' ${ }^{1}$ Pref. 4. XXVIII (v. L. § 9, Il. anm. p. 13).

2) $i$ occurs in: afirde I. 34, V. 17; first VI. 31, IX. 21; smiredon, smirinis VI. 13, XVI. 3, 4, 5, 8, XVI. 1, Pref. 5. XLIV (cf. L. $§ 9$, anm. p. 14), (beside bismerigende v. § 4.2). Sievers, $\S 100 \mathrm{a}$, regards this $i$ as a later development of $i e$, the $i$-umlaut of $e o$. Sweet, H. E. S. $\S 469$, gives "Gmc. $i$ in afirran".

$y$ occurs in the ja-stem Adj. yrrestum Pref. 4. XXXVII.

815. The only example of breaking of $e$ to $e o$ before $l+$ Cons. is: seolfa III. 25 etc. (11), (v. $\S 186$, S. $\S 81$. sulfne III. 26).

(For the Palatal-umlaut of $a$ and $e$ before $h+$ Cons. and $r+$ Pal. v. §§ 19, 21).

$$
u \text { - and } o-(a-) \text { umlaut. }
$$

816. The $u$ - and $o-(a-)$ nml. of $e$ appears as $e o$, $e a$; of $i$ as io; $a$ is not affected (v. S. $\S 160$, the form geafel XII. $14=$ WS. gafol, is probably not an exception to this rule, but an example of the influence of a preceding palatal v. $\S 29$ ). As a rule this umlaut penetrates only through a single consonant (S. § 103) the only exception is behianda V. 27, VIII. 33 (v. S. $\$ 160)$.

1) $u$-, $o$-uml. caused by an original $u, o$ of a derivative suffix:

$e$ occurs as eo in: feolo VI. 34 , VIII. 5 etc. (6), (v. $\$ 155$. S. § 106, anm. 2); feotrum V. 4 (fattro V. 4, v. farma § 13. 3); heofon, heofne VI. 41, XIII. 25 etc. (19), (v. § 78. IV); heono (ecce) VI. 3 etc. (11), heonu I. 2 etc. (4), (herio VIII. 2); seofa (septum) VIII. 8,20 etc. (11), (v. § 178).

ea (v. Sw. H. E. S. $\S 435$ ) in: seatlas XI. 15, -um XII 39 (setla (2) v. § 4).

In wealigo XII. 41 the vowel has perhaps been taken over from the sb. v. weala VI. 19 (v. Paul, P. B. B. VI. p. 234. Zeuner considers it to be umlant caused by the suffix orig. -og, -ay, v. §§ 23. II. 1 and anm., 8. II. 1).

1 geriordade glosses Latin pauescens. Was the glossator thinking of uescens? Cf. exsiliens X. 50 treated as if siliens, $\nabla . \S 136.6$. Note. 
Umlaut does not occur in efolsong VII. 22 etc. (v. §9, note), and it is regularly (v. S. $\S 105$ ) wanting before a palatal consonant, as in recone etc. (v. $\S 20)$.

2) caused by an inflectional $-u,-o(-a)$ :

$e$ occurs as eo in: cweoða Pref. 1. 11 (cuoeða v. § 32); geofa Pref. 5. XLI (geafa VII. 11. (2)).

ea occurs a) in the following sbs.: gebeadum IX. 29 ; geafa VII. 11 (2); weala IV. 19 (walana v. $\S 36$ ). b) in the following vbs.: beara VI. 55, eata VII. 2, VIII. 1 etc. (6), eatas VII. 5. 28 (v. $\$ 128$. I beside ettanne VI. 37); -freattas XII. 40; -geafa II. 7, XI. 26, XV. 6, -geafas XI. 25, XIV. 12; begeatta XIV. 5; seofade VIII. 12, seofende X. 22 (е̌o v. P. B. B. X. p. 507, not $\hat{e} o$ as given in B-T.); getearende IX. 26 (v. S. $§ 370) .{ }^{1}$

817. The $u$-, o-(a-)umlaut of $i$ is io. It occurs 1) in wk. vbs. Cl. II: cliopia X. 47, cliopade IX. 26 etc. (8), (v. $\$ 134$ ), gecliopad VIII. 34, cliopende V. 5 etc. (8), (v. § 103); gehlionade XIV. 3, gelionede II. 15 (beside linigiendo etc. (3); lifgiende etc. always with $i$, v. $\S 8.2$ ).

2) In Pres. forms of the st. vb. nioma II. 2, III. 27 etc. (5), -niomad (3 ${ }^{\text {rd }}$ sg.) IV. 15, niomas (plur.) XVI. 18, -niomme (Subj. sg.) XIII. 15 (v. § 127); and in the Pret. pl. geflioton IX. 34.

3) Other words: hiora I. 5, 23 etc.; liomana Pref. 4. XXX; nioðuord XV. 38.

\section{Palatal umlaut.}

8 18. $e a$ before $h, h t, x(=h s),($ v. S. $\S 82)$ is palatalised by the influence of the following $h$ to $a$ (v. S. $\S 162$, L. $\S 11$, Sw. H. E. S. $§ 438$ ).

1) $e a>a$ before a final $h$ in: gesceh IX, 14, 15 etc. (20), -saeh V. 38, VI. 34 (ae for $a$ v. § 3).

2) $e a$ before $h t$ generally appears as $\alpha$, but occasionally as $e$ and $a$.

a) in the Pret. of the Irreg. wk. vbs. (v. $\S 132$, III. S. $\S$ 407): awaehton IV. 38 etc. (3); beside undehton II. 4 (v. S. $§ 162$, anm. 2), (cf. embeht- below); and gelahte VII. 33 etc. (5).

b) other words: most (sb.) VI. 5,7 etc. (20), meeghte IX. 1, moehto (adj.) X. 27; mahte (vb.) V. 3, 4 etc. (20), maehton III.

${ }^{1}$ For a further investigation of this subject $v$. Lindelüf "Ueber die Verbreitung des sogenannten $u$-(o-)umlauts in der starken Verbalflexion des Altenglischen". Archiv für das Studium der Neueren Sprachen und Litteraturen. Vol. LXXXIX. pp. $129 \mathrm{ff}$. 
6, VII. 24, XIV. 11 (จ. § 137. 7); mahtig IX. 29 etc. (5); nwht IV. 27 etc. (8) (v. § 166. II); ठchtuny III. 6, XV. 1, Pref. 2. IX; beside $e$ in : embeht-monn IX. 35, X. 43, XIV. 65 (embiht- XIV. 54), ge-embehta (vb.) X. 45 etc. (4), (v. § 134).

3) $e a>a$ before $x(=h s)$ in: waxes I. 6 etc. (6), (v.129. I).

8 19. eo before $h, h t, x$ (=hs), (v. S. §83) is palatalised to $e$, and in a few instances to $a, i$.

1) $e o>e$ before final $h$ in: feh XIV. 11 ; beside $a$ in: gesach (uide) XV. 4, and $i$ in: gesih I. 44, XIII. 1, 2.

2) $e o>e$ before ht in: breht Pref. 3. XI, 5. XLII, behrto Pref. 2. V (v. § 85. 2); gefehto XIII. 7; leht- IV. 21 (2), Pref. 3. XII, lecht XIII. 24; rehta, reht- I. 3, II. 22, VII. 21 etc. (9); beside $\alpha$ in: cncehta VII. 28, IX. 24, 36, 37.

3) $e o>e$ before $x(=h s)$ in: sex, -tig IV. 8, 20, IX. 2.

4) The $i$-umlaut of this $e$ is $i$. The only examples are: lixendo IX. 3, inlihted Pref. 4. XXXIV.

8 20. $e o$ before $c$ and $g$ (caused by $u$-, $o$-umlaut) does not occur (v. S. § 164. 2, Sw. H. E. S. § 440, ef. L. § 11. II). $e$ occurs regularly in : spreca I. 34 etc.; recone I. 29 etc.; erenwreca Pref. 2. $\mathrm{V}$ etc. (v. § 4).

io appears as $i$ (v. S. $\S 164.3$ ) in: cuic-lacum XII. 33 (v. § 37. 2).

8 21. $e a>e$ before $r e, r g$ (v. S. § 162. 2). The examples are: berga (porcorum) V. 11, 12, 13, 16; -merca XII. 16, XV. 26, XVI. 17, Pref. 1. heading, 14, 5. XXXVIII. a remained unbroken to $e a$ in carcern VI. 17, 27 (v. §11. 1, S. § 79, anm. 3).

82. $e o>e$ before $r c$ (no example of $e o$ before $r g$ occurs) in: wercas V. 14, Pref. 1. 10, 14 (beside warcco XIII. 8; and woerc v. $\S 35$ ).

The $i$-umlaut of this $e$ is $i$ : gebiryed IX. 1, gebirigdon Pref. 4. XXVII. (For nyrca v. §27).

\section{$i$-umlaut.}

82. The $i$-umlaut of $a$ before Nasals, and before other consonants (exclusive of $l+$ cons. and $r+$ cons. v. $\S \S 24,25$ ) is as a rule $e$. Before $s t$ and $c c, g, c g$ it is generally $a$ (v.S. $\S 89$, anm. 1). The examples are:

1) before consonants other than Nasals: bed IV. 21, VII. 30, XIV. 15; betra IX. 32, 43; eft III. 39, IV. 24, V. 21 etc., 
eftersona II. 1, VIII. 1, 13, 25 etc.; eher (spica) IV. 28, Pref. 2. VIII (v. S. § 289); ellðiodade XIII. 34; esne X. 44, XII. 2, XIV. 47, 51, XVI. 5; feder (dat. sg.) VII. 10, 11, 12; -feredon I. 32, II. 3, XI. 16, XIV. 36; hefig X. 23, XIV. 6, 40; here IV. 36, V. 9, X. 46, XII. 41; hered Pref. 2. IV; legdon XI. 8; metto VI. 36, VII. 19 ; nesc XIII. 28 (v. § 101. 2); hnetta, netto I. 16, 18, 19 (v. $\$ 101.1$ ); ondetende I. 5, VIII. 38 (2), Pref. 2. IV, 4. XXVI (v. S. § 403, anm. 2, L. § 12. I a.) For falletande V. 5, v. $\S 104.2$; sceððаð XVI. 18; sellanue, sellas X. 40, XIII. 22 etc. (25), (v. § 131, beside sealla etc. (9), v. §12), selenisse VII. 3,5, 9, Pref. 5. XLV; -settanne, -settað etc. XV. 36, XVI. 18 etc. (36), (v. § 132. II, beside gesatte Pref. 3. XI, without umlaut v. S. § 401. 2), setnesse VII, 3, 5, 8, 13, Pref. 1. 14; teherum (lacrimis) IX. 24 (ef. L. § 24. 1); tellanne Pref. 1. 15; unठuegenum VII. 2, Pref. 3. XX (v. S. § 392. 2); twelfo III. 14, IV. 10 (tuoelf v. § 32. 2,3). Scand. loan-word: geeggedon XV. 11.

Beside $e$ occurs $a$ in the compound words: huelc VIII. 4 , IX. 34 etc. (15), huselc I. 27, IV. 24 etc. (11), (beside huoelc (6) v. $\S 32$ ); and swelc X. 15, suelce IX. 26 etc. (8), swoelce I. 22, XIII. 19 (beside suvelce (2) v. § 32 , v. S. § 342).

2) before Nasals: bendum V. 2, VII. 35; brengende II. 3, 4 etc. (6), gebrenginise XII. 44; cempo XV. 16; cennise VI. 21, Pref. 1. 11, 3. XVII, acenda (nata) XIII. 28; -drencdo V. 13; ende III. 26, XII. 6, XIII. 7, 13, Pref. 1. 9, -endade X. 11, XIII. 4 (2), Pref. 1. 14; lond-bigencgum (agricolis) XII. 1 (Hilmer v. p. 47 considers this word a form of lond-byend v. Rushw. John XV. 1, but in B-T. it is rightly given under land-begenga, cf. OHG. lant-pikengeo); gefremðia (anathematizare) XIV. 71 (v. § 97. 3); glencas XIII. 2; leng IX. 8 etc. (i), (v. $\$ \S 175$. I, 177); menig IV. 5 ete. (22), (beside monig (29) v. § 2. 3), menigo (sb.) II. 4, III. 8 etc. (6), (v. $\S 160)$; menn I. 25 etc. (22), (v. $\S 166$. I); nemned VII. 26, XII. 41, Pref. 2. I; penningum VI. 37, XII. 15, 42; rendon XI. 8, XIV. 63, to-reded (scissum) XV. 38 (miswritten for -rended? v. § 90. 3); senda VII. 27, XI. 23 etc. (40), (v. §§ 132. II, 133. II. etc.); stences XIV. 3 ; stengum XIV. 43,48 (v. § 100. 5); strengo XII. 33; temised (propositionis) II. 26; temma V. 4; aðenede III. 5 (2); Jencendo II. 6, VIII: 18, XIII. 11.

Loan-words: engel I. 2, 13 etc. (9), (v. § 76. I). oe occurs in: fot-scoemel XII. 36 (v. §26, ef. Pog. § 261).

Anglis. N. F. IV. 
Lengthening of this $e$ before $n d$ is marked by an accent in efnesênde X. 11.

3) Before st occurs $a$ in: gefoste XII. 1; rast- II. 15, 27, 28. III. 4, IV. 39, XIV. 41, XVI. 14, beside $e$ in: rest- II. 27, VI. $26,31$.

4) Before $c c, g, c g$ occurs $a$ in: acced- XV. 23, 36; loeccanne XIV. 48; ic sago, sacgende V. 41, Pref. 1.6 etc. (12), (v. $\S 136.2)$; wacca, nacccas (uigilare) XIII. 37, XIV. 33, 34, 37, 38 (v. S. § 416, anm. 6 ; beside gewaccas XIII. 35, v. § 1. 1); eft-awacce (resuscitet) XII. 19, Pref. 3. XIV (2); gewage (mensura) IV. 25.

No te. WS. $\hat{e}$ from compensation lengthening of $e$ after loss of $g$ appears as $i(=\hat{\imath})$ in gehrino (aedificationes) XIII. 2 (v. B-T. ge-rên, C. $\S 13$ ).

82. The $i$-umlaut of a before $l+$ Cons. is $a(=\hat{a}$ v. S. $\S 159.2)$.

The examples are: celdesio XI. 27, XIV. 53, celdra VII. 3, 5, Pref. 3. XX, (aldrum XIII. 12, v. § 175. I), celdo II. 16, VIII. 31, XIV. 43, XV. 1; gefaello (ruituras) Pref. 5. XLII; ge-waeldes (dominantur) X. 42, (onweaeld XIII. 34 v. S. § 267, Nachtr., ef. L. $\$ 9$ I. 2 b. eae $=\propto$ (ae), "geheaeld (custodiam) ist wohl = gehoeld"); towaelte (aduoluit) XV. 46, XVI. 3, 4.

85. The $i$-umlant of $a$ before $r+$ Cons. is $e(=\hat{e}$ v. S. $\S 159.1$, ef. L. $\S 12$. I $\beta$ ).

The examples are: -bernde IV. 6 ; gecerde V. 30 , VIII. 33 etc. (10), (v. $\$ \S 132$. II, 133. II, beside $a$ in: carrende XV. 29, gecarred Pref. 1. 2); derne VII. 21, VIII. 38, X. 11, 19; erfe XII. 7 (2); gegerelo II. 21, V. 28, XI. 7, gegerelad I. 6, V. 15 (v. § 82. II); gerd VI. 8, XV. 19; gehwerfed IV. 12 (huoerf VIII. 37 v. § 32); merrunga (seductiones) Pref. 5. XLII.

826. The $i$-umlant of $o$ is $o e, e$. (For the rarity of its occurrence v. S. $\S 93$ and anm.) The examples are: doehter (dat. sg.) Pref. 3. XVII; on merne (mane) XV. 1 (ef. mergen S. § 93).

Loan-word: oele- XI. 1, XIII. 3, XIV. 26 (beside ole VI. 13, v. \&9.3). oe $=i$-nmlaut of $a$ before Nasals in fot-scoemel XII. 36 (v. § 23. 2).

82 27. The $i$-umlant of $u$ is $y$. In a few instances $i$ for $y$ occurs (cf. $y$ for $i$ v. (2) below), and very rarely $y$ is written $u i$ (v. S. § 6, anm. 1). 
1) The examples of $y$ are: bycges VI. 46, 37, X. 21, XI. 15 (3); byrgen XVI. 5, 8 etc. (11), (จ. § 146); byreð IV. 38; byrig V. 20 etc. (4), (จ. § 166. II); byrden IX. 42; bytto II. 22 (4), Pref. 2. VII; -crypel II. 3, 4, 5, 9, 10, Pref. 2. VI; to-cyme (adventus) Pref. 5. XLIII; gecynd Pref. 2. 4; cynn IX. 29, XIII. 8 ete. (9); cynig VI. 14, 25 etc. (9), cyning VI. 26, XIII. 9 (2); ymb-cyrf Pref. 4. XXX; cyssende XIV. 44, 45 (จ. § 103); cyrtlum VI. 9; adrysned (extinguitur) IX. 46 etc. (6), (v. §78. IV); dyntum XIV. 65 ; fylga VIII. 34, X. 21 etc. (30), (v. §§ 132. II, 133. II etc.); fyllnise II. 21, Pref. 1. 9, 14, gefylle (Inf.) VIII. 4 etc. (11), (v. $\$ 132$. II, 133. II); fyrhto IV. 41, IX. 6, XVI. 8, gefyrhtad IX. 6; gyrdils I. 6, VI. 8, ymbgyrded XIV. 51; blodes gylt Pref. 3. XIV; oferhygd VII. 22 ; hyngerde II. 25, XI. 12 (v. § 100. 5); -myndig XI. 21, XIV. 72, gemynd XIV. 9, gemyne tu Pref. 1, heading; mynetro (nummularium) XI. 15; nymঠe II. 7, 26, III. 27, Pref. 3. XV; scyld III. 29. (2), XIV. 64; ge-scyrte XIII. 20. (2), (v. § 95); smyltnis IV. 35, 39, Pref. 3. XIII; snytru VI. 2; ge-ondspyrned VI. 3 etc. (4), (beside -spurnad IV. 17, v. 126. I); stycas XII. 42; styres (vb.) V. 35, 39, VI. 50, IX. 20, XUI. 25, styrenise XIV.2; symbel (cenam) VI. 21, XV. 6; syndrigon IV. 10, 34, Pref. 2. 2, 3. XI (beside sundrig etc. (4), v. $\S 10.2$, suindrige (3) $\nabla$. (4) below); synge $\mathrm{X} .12$, synna, synn- I. 4, 5, II. 15 etc. (14), (v. §§ 103, 147. I); synnig III. 29 etc. (4), (beside sunigo II. 15); Jyncge XIV. 64; dyrnenne XV. 17 ; dyril X. 25 (v. S. § 218); trymnises Pref. 2. 5, V, IX, trymende XVI. 20, -trymigo VI. 5, 13, 56, XIV. 38, XVI. 18, wyrtryma IV. 17 (beside trumlice etc. (4) v. § 10.2); wyrce (Inf.) III. 4 etc. (11), (จ. § 113.2 etc.); wyrihte (faber) VI. 3 (v. § 76. II, wrihtes Pref. 3. XV); wyrm IX. 44, 46, 48; -wyrpnise III. 15; wyrtum IV. 32, XVI. 1; yfel VI. 49 etc. (11), (v. § 78. 1); ymb I. 6 , III. 8 ete.

For the origin of $y$ in WS. $d y d e$ and in North. styd beside WS. stede (v. S. $\$ 263$ and anm. 5) v. Sievers, P. B. B. XVI. pp. 235, 236. The examples are: dyde VIII. 6 etc. (19), and with the vowel of the singular taken over to the plural: dydon VI. 30 etc. (4), (two instances of the older plural are: dedon III. 6, VI. 12 , v. $§ 140$, ef. S. §429); styd I. 35 , VI. 32 etc. (4).

For $y$ in the Pres. forms of the st. vb. WS. cuman, ef. L. $\S 49$, p. 89 , v. S. $\S 390$, anm. 2 . The examples are: cym, cymende V. 23, IX. 1 etc. (30), (beside cummende etc. (5), จ. § 127).

Note. The word wyrdes (rigat) Pret. 2. 5 is obscure. 
2) $i$ for $y$ occurs in: drihten V.19, XI. 3 etc. (22), (v. $\$ 76$ III), drihtes Pref. 1. 6; scile (subj.) IX. 12, XIV. 31, 62 (v. Panl P. B. B. VI, p. 43); wrihtes Pref. 3. XV (wyrihte v. (1) above). $e$ for $y$ occurs in ende brednise (ordinem) Pref. 1.4 (v. S. $\S 180$, cf. Z. $\$ 30$ and anm.).

3) $y$ for $i$ occurs in: espryngc V. 29 (v. C. § 34. 2); styldon (stupebant) I. 22, V. 42, VI. 51, X.24, XVI. 5; symle V. 4, 5 etc. (6), (v. § 92); wynnennde VI. 48; wynstra X. 37, XV. 27 (winstra X. 40).

Note. fihles (panni) Pref. 2. VII is possibly a metathesised form ( $\nabla . \S 87)$ from a Lat. base plec-, with $y$ for $i$ in flyhtes II. 22?

4) ui (iu) for $y$ occurs in: suindrige IX. 2 (swyndria XIV. 19), siundrio Pref. 1.13 (beside syndrige (4) v. (1) above, ef. druige XI. 20, v. §55).

\section{Influence of Preceding Palatals.}

82. Initially the semivowel $j$ is always represented by $g$, except in proper names (v. $\S 83$ ). For its influence on a following $a$, $o$ v. S. $\S 74$, ef. L. § 13.1 .

The only example which occurs is: bigienda $\mathrm{X} .1$, (with $i$-umlant).

Examples of original $j u$ (v. S. § 74) are: gie (Pron.) II. 8

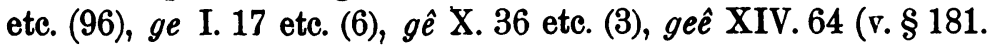
II.), (on the vowel ef. Brugmann. P. G. II. p. 810); gee (iam) VIII. 2 etc. (7), giee XV. 44 ; gigoðe X. 20; ging XIV. 51, XVI. 5.

In place of ie (S. $\$ 74$, anm. 1) in WS. giet, giena occur $e$ and eo: get VIII. 17, 21 etc. (7), gêt IV. 40; and geone V. 35, VIII. 17, 21, XIV. 43, 63.

8 29. In the majority of cases $a(a)$ preceded by $g, c$, $s c$ is changed to $e a$ (v. S. $\$ 74.1$ ), bat several forms occur with unchanged $a$, side by side with the $e a$ forms of the same word. $e a$ is sometimes written eae, and eae (cf. L. §13.2a). The examples are:

1) ea from $a$ preceded by $g$; geafel XII. 14 (v. § 16); atgeadre II. 15, VI. 22, XIV. 31, XV. 41, gegeadrad X. 9; forgeaf XV. 15 ; ongeat V. 30 .

The forms with eae, eae are: -geaf X. 4; ongeaegn XI. 2, XIII. 3, XIV. 13, XVI. 17.

2) ea from $a$ preceded by $c$ : ceastra I. 45 etc. (10); (v. $\S 146)$. 
3) ea from $a$ preceded by sc: sceacas VI. 11, sceacerum XV. 7 ; sceafte XVI. 15 ; sceal X. 17, XIII. 7; scealt X. 21 ; morsceaðe XV.11, 15, 27.

With ea: sceafles XIII. 19 (cf. ea for $a=\hat{e} i$-uml. of $\hat{a}$ from ai in toscande V. 4 v. $\S 42.1$ ).

4) ae remains unchanged (v. § 3) in: agof XII. 1, XV. 37 (beside -geaf 2); ongagn XII. 41 etc. (4), (beside -geaegn 4); gcet (sb.) I. 33; -gcet (vb.) XV. 45 etc. (4), (beside -geat 1); scaeftes X. 6 (beside sceafte 1 , sceerftes 1 ).

Thus the numbers are: ea 26 ; ece, eae 6 ; a, ae 12 .

5) The only example with $i$-uml. is: Jeodscip Pref. 2.3 ( S. $\S 98$, anm.).

8 30. 1) WS. $\hat{a}$ North. $\hat{e}$ (v. § 44) remains unchanged in: on-geton VI. 33 etc. (4). It appears as $\hat{\imath}$ in: scîp (oues) VI. 34, XIV. 27, with an accent over the vowel in both instances to distinguish the word from scip (nauis).

2) $e$ appears as $y$ in: gyld (sb.) Pref. 4. XXXVIII (v. S. $\S 75$. 3); otherwise it remains unchanged: geldas XII. 17; ic forgefo XV. 9 etc. (v. $\S 4)$.

83. Other vowels remain nnchanged after $g$, and $c$ as in WS. (v. S. $\S 76.1$ ), except $o$ (=a before Nasals) in WS. gongan, North. geonga. $\hat{a}, o, \hat{o}$ are changed to $\hat{e} a, e o(e a), \hat{e} o$ after $s c$ (v. S. $\S 76.2$, L. § 13. 3). The examples are:

1) $\dot{e} a$ in: to-sceadade IV. 34, X. 9, Pref. 2. 3, 5. XLII.

2) eo in: -sceomfulnise VII. 21, Pref. 5. XXXVIII; sceortum Pref. 1. 13, 5. XLVI; ea in: scealde X. 32, XIV. 40.

Note. sceofmum (contumeliis) XII. 4 is apparently miswritten for sceomum ef. Rushw. scomum, and Luke XI. 45 where contumiliam is glossed by sceoma.

3) $\hat{e} o$ in: gesceop XIII. 19. $\hat{o}$ remains unchanged in gescoed (calciatos) VI. 9 (=gescô-ed v. $\$ 135.2$ ).

4) $e o$ in the Pres. forms of the vb. geonga occurs 35 times (v. $\$ 130$. I.), in geongas (sb.) I. 3, V. 13 etc. (6).

Note. The word geanðe in from geande $l$ sunduria (deorsum) XIV. 66 is obscure. The gloss sunduria shows that the glossator has muddled seorsum and deorsum; cf. seorsum $=$ sundrig VI. 31 , seorsum $=$ sundu $\bar{r}$ VI. 32. Can from geanðe = trom gânde (= going away from, going apart) with $e a$ for $a$ or $a a$ ? (v. $\S 38.2$ ). For instances of $\delta$ for $d$, v. $\S 96$.

Influence of Preceding $w$.

83. $e$ (= Gmc. $e$, and umlauts- $e$ ) immediately preceded by $n$ is, as a rule, changed to oe, and occasionally to ooe (ct. 
ece beside $e a \S 29)$ and $o$ (v. $\$ 35)$, but $e$ remains unchanged in several instances.

1) oe (Gmc.e) occurs in: cuoeða, gecuoeden II. 9, V. 36 etc. (87), coeðe (with loss of $w$ ) I. 44, II. 9, X. 19 (v. § 128. I, IV); huoelc huoego VIII. 23, XIII. 15 (v. S. § 344); woeg VI. 8, VIII. 3 etc. (16); gewoegen (pp.) IV. 24. (2); woel VII. 9, XII. 28, XIV. 7. The forms with oce are: cuoceras XII. 18, XIV. 69, XVI. 17; with o: cuodas X. 18, cuodende V. 35, XII. 18, XIV. 60; huodhuoge XV. 24 (cf. § 35).

2) oe (umlants-e) occurs in: acuoellad X. 34, XI. 18, XIII. 12; huoelc VIII. 29, 37 etc. (6), (v. § 23. 1); huoelpes (catelli) VII. 28 (Sweet, O. E. T. Gloss. p. 542, classes this word under umlauts-e. Kluge, Germ. Dict. gives it as Gmc.e); huoenne (quando) VIII. 20 etc. (6), (v. P. B. B. VI. p. 32); huoerf VIII. 37; suoelce VIII. 24, 28 (v. § 23. 1); geswoenced I. 34 (2); gesuoeria XIV. 71 (v. S. § 392. 4); in að geswoerenum (iúsiurandum) VI. 26, WS. -sworen, -swaren the vowel has apparently been taken over from the Inf. (but v. § 71. 1); tuoelf VI. 43 etc. (15), (v. § 178); awoendat Pref. 1. 11.

3) $e$ (= Gmc. $e$ ) remains unchanged in: ic cueðo, acueðen ( $\delta$ for $d$ ) II. 11, Pref. 1. 15 etc. (6), (with oe (90), ooe (3), o (4), cueoða Pref. 1.11 with $u$-, o-umlaut v. $§ 16.2$ ); wege I. 2 (with oe (16); wel III. 4 etc. (6), (with oe (3).

$e$ (= umlants-e) remains in: huelc VIII. 4 etc. (15), (beside hucelc (11), with oe (6); suelc X. 15 etc. (8), (beside sucelce (2), with oe (2); twelfo III. 14, IV. 10 (with oe (15).

8 33. $a$ (= Gmc. $a$, v. § 3) immediately preceded by $n$ generally remains unchanged. It only occurs as $o e$ in the $1^{\text {st }}$ and $3^{\text {rd }}$ pers. sg. of the Pret. Indic. of the st. vb. WS. cweran, and in the Conj. WS. hwarer (v. S. § 156).

1) The examples of oe are: cuoet VI. 18 etc. (141), (v. $\S \S$ 107, 128. II), coed (with loss of $w$ ) XII. 26, 35, XIV. 22 (cuoea VII. 6); huoeঠer VIII. 23, X. 43, XIII. 11, XIV. 29, XV. 44.

$o$ occurs in the compound word huodhuoge (quid) XV. 24 (v. S. § 344).

2) Examples of unchanged $\alpha$ in these words are: cuce II. 27 etc. (9), (beside cue $\delta$ (19) v. § 3. 3, with oe (144).

$e$ for $a$ occurs in hue 
8 34. $\hat{e}, \hat{a}$ (= Gmc. $\hat{a}$ v. § 44) immediately preceded by $w$ is changed to $\hat{o} e$, but not regularly; instances of unchanged $\hat{e}, \hat{e}$ are numerous.

1) $\hat{o} e$ occurs in: Pret. forms of cuoe $\partial a$ (41), (v. § 128. III); woede V. 27 etc. (7), (v. $\S$ 144. I, 145. I), gewoede VI. 56, XV. 20 (with $i$-umlaut v. $\S 45$, beside gevedo V. 30 ); woepen X. 6 ; woere, woeron V. 14 etc. (26), (v. $\S 138$. 3. weoron IV. 10 is apparently a scribal error for woeron; ymb-woeson Pref. 1 . heading, woeson for woeron? $\nabla . \S 86)$; and in the following words where $\hat{o} e=\hat{e}$ of varions origins: swoer (socru) Pref. 2.V (v. $\S$ 46. 2); tuoege VI. 31 etc. (8), (beside tuoge VI. 7 etc. (3), v. $\$ 178$ ); uoe (nos) X. 33 etc. (v. $\$ 181$. I, S. § 156).

2) $\hat{e}, \hat{a}$ occurs unchanged in: Pret. forms of cuoe $\partial a(7)$, (v. § 128. III; with oe (41); were, weron IX.10 etc. (56), beside ware (4) v. $\S \S 44.3,138$. 3, with oe (26).

swer I. 30 (swoer Pref. 2. V); tuege Pref. 5. XLI etc. (3), (v. $\S 46.3$, with oe, o (11); we I. 38 etc. (about 32 , with oe (5), v. $\S 46.5$ ).

For huer, hucer, swae, swa v. §44.2, 3.

835. The group weo (from Gmc. we) due to breaking, appears generally as wo; the group weo due to $u$-, o-umlant, appears as wo less regularly (v. examples $\S 32.1$ ). The examples are:

1) Breaking: suordum XIV. 43, 47, 48; worpend I. 39 etc. (4), (v. § 126. I); worð (atrium) XIV. 66 etc. (4); worðedun H.12, V. 6 , VII. $6,7,10$, XV. 19, worðnis etc. VI. 4 (2), X. 19, Pref. 3. XV; geworde (fiant) XIII. 30, XIV. 2.

oe occurs in: woerces XIII. 34 etc. (5), (beside werc, woercco (4) v. $\S 22$ ); and in coern IX. 42 (with loss of $w$, v. S. $\S 172$, anm.).

2) u-, o-umlaut: woruldes IV. 19, Pref. 4. XXXII, world X. 30 ; wosa IX. 35 etc. (9), (v. § 138. 3, S. § 156. 2), and the derivative formed from this Inf.: forwost VI. 21, and margin, Pref. 4. XXIX. For cuoðas, -huoge beside the commoner forms with oe v. $\S 32.1$.

swoester (always with oe) III. 35, suoestro VI. 3, X. $29,30$.

8 36. The group wea (= weo from Gme. we) due to $u$-, oumlaut, appears as $w a$ and $w a$ (v. S. $\S 156.3$ ) in: walana IV. 19 (beside weala IV. 19 , wealigo XII. 41, v. §16.1); waras I. 5, 33, waro VI. 44, Pref. 3. XVIII, warana VI. 44. 
8 37. The group wio (from Gmc. wi) due to breaking or $u$-, $o$-umlaut, appears as $w u$ (v. S. $\S \S 71,156.4$ ) in most of the forms and derivatives of the Pret. Pres. verb WS. witan, otherwise as a rule $w i$ remains. The $i$-umlaut of this wio is $w y$.

1) $w u$ occurs in: wudu I. 6; wutta (scire) VII. 24 etc. (13), (v. § 137. 1); uиঠwuta (scriba) XII. 32 etc. (19), uðuta (with loss of $w$ ) I. 22, II. 16 (v. $\S \S 38.2,75,157$ ); uutedlice IV. 11,15 etc. (20), wutum I. 38, XII. 7, XIV. 42.

2) wi remains in: cuic IX. 49, XII. 33 ; suuippum (fiagellis) XV. 15, geswipernise XII. 15 (v. L. \$14. 4, anm., C.N. 143 “geswiopernise alt. to -"); bituih II. 8 ete, (11), (bitwien IV. 41, bituen VIII. 16, v. $\S 180$, S. $\$ \S 71,329$ ); vidua XII. 40, 42, 43, Pref. 5. XLI; wiht VI. 49; fuluiht I. 4 etc. (10), (v. § 150), fullwihtere VI. 14 ; wita (Subj. pl.) IV. 11.

3) $w y$ (due to $i$-umlaut) occurs in: wyrðe I. 7, X. 14, XIV. 3,$4 ;$ wyrse V. 26.

\section{Chapter II. Long Vowels.}

8 38. As a rule long vowels are not marked, but the nunber of instances where length is denoted either by an accent (, , rarely ${ }^{\prime}$ and ${ }^{-}$) or by doubling of the vowel is by no means small. Some words occur more frequently with an accent than without, e. g. ric 16 , beside ric 6 ; tîd 17 , beside tid 5 ; or with doubling of the vowel, huu 20, beside $h u 2$; and gaa, slaa always with $a a$. In a few instances lengthening of a short vowel before consonant groups is denoted by an accent. Misplaced accents are rare.

1) Accented vowels: $\hat{a} c$ VIII. 28; $a n$ X. 21, XII. 6, XIV. 47, ane Pref. 1. 16; arlice XI. 20; bât I. 26; bêr (grauatum) II. 4, 11, 12; blôd XIV. 24; bôc X. 4, Pref. 1; gebrêc I. 6, II. 26 (v. § 61); brâca III. 20, brâcende I. 6; dêd Pref. 2. V; dôm XII. 40; drâf XI. 15; fordrâf Pref. 2. IV, 3. XIII; $\hat{e} c$ I. 38, II. 13, IV. 5,41 ; êce III. 29, X. 17, 30; êdmodað IV. 41; anêge IX. 47; fôt IX. 45; gâst I. 12, gâstas V. 13; gê (Pron.) X. 36, XI. 24, XII. 24; gêmde I. 34; gêt IV. 40; gôd X, 51; cildhâd IX. 21, sacerd-hâd Pref. 1. 16; hâl I. 31, V. 23; hâtas I. 27; gehêned IX. 12; hêra (minister) X. 43; gehêred II. 1, ge-hêrdo Pref. 2. IX; hlaff (uxorem) VI. 17; hrinande I. 41; has V. 3, Pref. I. 8; huề XV. 47, sua-huêr IX. 18; lâr I. 27, IV. 2, VI. 2, XI. 18, 
Pref. 1. 5, 3. XV, XXIV; alêfed II. 4, III. 7; lîcðrower I. 40, gelîc IV. 16, XII. 22, XIV. 31, gelîc-leta IV. 30, gelîcad Pref. 4. XXXIII, ungelîcum Pret. 5. XLII; lîf X. 30; mîn I. 11, V. 23, IX. 17;

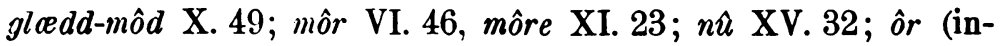
itium) XIII. 8; arâs I. 35, II. 12, IV. 17, VI. 14, XVI. 6, arîs II. 9, III. 3, V. 41, arîsq III. 26; rêdes (vb.) Pref. 1. 7, rêdes (sb.) Pref. 1. 5; ric I. 15, III. 24 (2), IV. 26, IX. 47, X. 14, 15, 23, 24, 25, XI. 10, XII. 34, XIII. 8 (2), Pref. 4. XXVII, XXXII; unrôts-

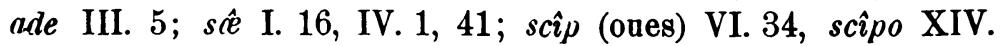
27; scôe I. 7; sêd IV. 27, XII. 21; sîdo I. 6; loslât XIV. 63; onsôc XIV. 68, 70, Pref. 3. X, onsôce Pref. 1. 15; sôec II. 14, sôecenda Pref. 4. XXXI; sôna I. 42; sônum Pref. 1.9; sprêc VI. 2, XII. 38, Pref. 5. XL; strèt IV. 4; têam XII. 22; tì I. 15, II. 19, IV. 29, VI. 35, XI. 11, 13, XII. 2, XIII. 11, 32, 33, 35, XIV. 35, 41, XV. 25, 33, 34, tìde X. 30; jrêat III. 32, VI. 34, Jrêad III. 7; tô II. 13; âsig I. 24; ût I. 34, at-gaas VII. 19, ata III. 31; ic nât XIV. 71 ; wôedo X. 50 ; woênlic XIV. 59; awrât Pref. 1.3 ; $\hat{y} \circlearrowright$ IV. 37; and with a difference in the form of the accent, eton VIII. 8, 9; hèr VIII. 4; Jrim VI. 21, margin; aldordōm X. 42; 万as leū̃ (leuiticae) Pref. 1. 4.

2) Doubled vowels: feerlice XIII. 36, feer-suigo V. 42; gaa (Imp.) I. 44, II. 9, V. 8, 19, 34, VII. 29, VIII. 26, X. 52; gaas VI. 10. 11, XVI. 15, gaað VI. 38, XI.2, XIV. 13, gegaas VIII. 26, ingaa (Inf.) IX. 43, ingaas VII. 18, ingaad III. 27, VII. 19, X. 15, inn-gaas VII. 15, X. 23, ût-gaas VII. 19, utgaað VII. 20; gaast I. 8,10 , V. 8 , VII. 25, IX. 17, 20, 25, XII. 36, XIV. 38, Pref. 2. IV, 3. X, gaas XIII. 11 (with loss of $t$ v. $\S 95$ ), gaastas V. 12, gaaste IX. 25; gee (iam) VIII. 2, XI. 11, XII. 34, XIII. 22, XIV. 41, XV. 42, XVI. 2, giee (iam) XV. 44 ; hee X. 6 , hiuu X. 6; hии II. 26, III. 6, 23, IV. 13, 26, V. 19, 20, VIII. 5.19 (2), 20, 21, IX. 12, 21, XI. 18, XII. 26, 35, 41, XIV. 1, 11; huulig (quales) XIII. 1; laar XII. 38; beleede XIV. 10; maara X. 43; maast IX. 34, maaste V. 42; neesta XII. 31, neesto XII. 33; ic see XIV. 19, hia see XIII. 30; we gesee (uideamus) XV. 32, ic gesii X. 51, XII. 15, бu gesiis XII. 14, خu gesiist V. 31; geslaa XIV. 65, of slaa VI. 19, VIII. 31, XIV. 1; 万riim VIII. 31, XIV. 5, tree XII. 26; tuи XV. 38; wusig XI. 9 (v, §§ 10. 3, 80), uиठwuta (scriba) XII. 32, uиঠииto IX. 11, 14, XI. 27, ииðииtum VIII. 31, XII. 28, мu內uиє III. 22, XII. 35, XIV. 53, X. 33, XIV. 43, XV. 1, 31, wuðuto II. 16 (v. §§ 37. 1, 54. 1). 
3) These two indications of length are combined in: $g a \hat{a} a$ (Imp.) I. 25, II. 11; geê (Pron.) XIV. 64; nêesto I. 38; sêe (sg.) XIV. 44, sêe (pl.) XIV. 29.

For bîtende (discerpens) I. 26; un-rôdt (tristis) XIV. 34; arisse XVI. 14, v. Sw. H. E. S. § 391 (v. § 95).

4) Lengthening of short vowels before a single consonant (Sw. H. E. S. § 384) and before consonant groups is marked a) by an accent in: wudu binde I. 6 ; blind X. 46 ; dom-êrn XV. 16 (ef. H. E. S. § 395); hîs III. 21; hônd IX. 31, XIV. 41; lônd I. 5, 28, 38, VI. 55; lônga V. 10, lôngiga XIV. 33; sáld VIII. 12, sálde XIII. 34; efnesênde X. 11; ôn Pref. 3. X; unclaene I. 23, an-eaðalice Pref. 4. XXXII; wôrd XIV. 39. b) by doubling of the vowel in: fuulvihta VII. 4; suundorlice XIII. 4 ; Jerh wurnon (percurrentes) VI. 55 (v. § 10.3), geuurnon IX. 15, efne-ge-uurnon VI. 33.

5) The irregular accents are: bist XIV. 30 (v. § 138, cf. Brown $\S 27$ e. "Westgerm. kurzes $i$ aus germ. $\hat{\imath}$ erscheint in $b i \delta$ (72 mal), bip (28 mal), einmal bitp"; v. Kluge, P. G. § 36.6. p. 372 "germ. biju bîz bì (= Lat. fio altir. biu) = ae. béo bĭs bì mit teilweiser vokalkürzung der Enklitika"); bolstâre IV. 38; fruma I. 1, frūma Pref. 1. 4, 7, 8; gehrinon Pref. 2. IX; lôsad Pref. 2. 1, lôswist IV. 19; nedrô XVI. 18, where the accent was evidently intended to be written over the $e$; ripes tîd (messis) IV. 29 (řp v. Sievers, P. B. B. X. p. 506).

a.

8 89. $a$ (= Gmc. $a i$, v. S. § 62) occurs regularly in:

1 ) the $1^{\text {st }}$ and $3^{\text {rd }}$ pers. sg. Pret. Indic. of st. vbs. of Cl. I. (v. § 124. II); in the Pret. Pres. vb. WS. wat (v. § 137.1); and in the Redup. vb. WS. hatan (v. § 130. I, III): bat I. 26; draf I. 15 etc. (7), accented (3), (v. § 38); -gegrap VII. 33; gehran I. 41 etc. (6); aras II. 14 etc. (11), accented (5); geras IX. 11; gesnað XIV. 47 ; toslat V. 4, accented XIV. 63; -stag I. 10 etc. (9); awrat X. 5, XII. 19, accented Pref. 1. 3; wat I. 24 etc. (4), nât XIV. 71; gehaten XI. 6, Pref. 1. 15, hâtas I. 27.

2) other words: an II. 7, IV. 8, 20, VI. 8, 15 etc. (36), accented (4), (v. §§ 178, 180); arlice (mane) XVI. 2, 9, Pref. 5. 16, accented XI. 20; ar- X. 19; geascade VIII. 5, XIII. 3, XIV. 60, XV. 1; að VI. 26; aðlo III. 10 etc. (4), (v. § 97. 2); claðas XIV. 63, gecladed V. 15: dalum (partes) VI. 40, VIII. 10; facen X.19, 
XIV. 1; fagungum Pref. 5. XLII; frasias IX. 16; gast I. 23, 26 etc. (11), accented (2), with aa (14); -hâd IX. 21, Pref. 1. 16; hal III. 4, V. 15 etc. (16), accented (2), (v. \$ 169 etc.); halig- I. 8, III. 29 etc. (13), (v. §§ 76. VI, 169. II etc.); ic halsigo V. 7; hlaf III. 20, VI. 8 etc. (about 23), (v. $§ 143$. I), hlafurd II. 28, XII. 9, XIII. 35; la X. 24, 47 etc. (8); -lacum XII. 33; hlaf (reliqua) IV. 19 etc. (6), accented VI. 17 (v. § 101. 1); lar I. 22, VII. 7, accented (7), with aa XII. 38, larua (rabbi) IX. 5 etc. (22), (v. § 75); la ठ XIII. 13; gemana XII. 25 margin; mara II. 21 etc. (10), with aa X. 43, maaste V. 42, IX. 34 ; ge-rahte I. 41 (v. S. § 407. 3); sauel VIII. 37 etc. (11), (v. § 72); snaua IX. 3; stan XII. 10, XIII. 2, XIV.3, XV. 46 etc.; tacon XV. 26 etc. (5), (v. § 71. 2); tahte XII. 38 (v. C. § 86, p. 101); бa I. 5, 19, II. 26, ete., Jam (dat. pl.) I. 20 (in all other instances ठarm v. § 182), ðara II. 5 etc. (12), (beside خara (6) v. § 182), ðas X. 42, XII. 40 etc.; wag- XV. 38; wanung (tumultum) V. 38.

Loan-word: caseri XII. 14, 17 (caeseres XII. 16, 17, v. Pog. § 199).

840. $a$ (= Gmc. $\hat{e}$ before $w$ ) occurs regularly in:

oncnawa Pref. 2.5 etc. (10), (v. $\S 130$. I, III. on-cneawes VII. $18) ;$ sauas IV. 18 etc. (14), (v. $\$ 130)$. Cosijn (\$ 58.2) gives as an example of this $a$ "cavelas (corbes)", the forms of which word in St. Mark are: ceaulas VI. 43 , cervlas VIII. 8 (v. C. $\mathbf{N}$. 143. "cenalas alt. to -"), ceolas VIII. 20.

The $a$ in WS. gân is of uncertain origin (v. S. $\S 57$, anm. 1, C. $\S 58$ ). The vowel is here always written $a a$ (v. $\S 38.2)$ : -gaa IX. 43 etc. (24) with $d a(2),($. $§ 141)$.

8 41. $a$ is due to:

1) lengthening of final $a$ in monosyllables (v. S. $\S 121$ ) in: hua II. 7, IV. 23, 41 etc. (suaha XI. 23, sua huce X. 44, v. $\$ \$ 185$, 186); sua XII. 33, XIV. 21 etc. (44), (beside suce (23), se (3) v. $\S 44.3)$; $\partial a$ (adv.) II. 20, 25, IV. 6 ete., $\partial a$ (Pron. ace. f. sg.) I. 21,45 , II. 19 etc.

2) contraction (WGmc. $a+o$ v. S. $\$ 166$ ) in : geslaa XIV. 65 etc. (4), (beside -slaeð (Plur.) IX. 31 ic Jershla XIV. 27 etc. v. § 129 , S. § 374 , anm. 1).

Note. $a$ in a half (demedium) VI. 23 is obscure. Rushw. has all. 
$\hat{\boldsymbol{e}}$.

8 42. The $i$-umlant of $\hat{a}$ (from Gme. $a i$ ) is as a rule $\hat{a}$. For the few instances of $\hat{e} \mathbf{v} . \S 46$. $\hat{e}$ is sometimes written $a e$, as in the case of the shurt vowel (v. $\S 3$ ).

1) Examples of $\hat{a}$ are: ce-laruas VIII. 15 etc. (3), as Pref. 2.3 etc. (3), (vgl. $\S 151$. III); næfra II. 12, XIV. 29; aghuelc XIV. 49 (beside eg- (6); anig, noenig IV. 22, V. 3, 4, 43 etc. (v. §§ 76. VI, 186); aniht V. 26 etc. (5), (v. § 186, S. § 348, Nachtr. $\S 100)$; ar XI. 4, XIV. 30 etc. (12), (v. $\S \S 175$. I, 177), on cering I. 35, XIII. 35; brcedon (stranerunt) XI. 8, IX. 7; unclane III. 30 etc. (11), (v. § 169 etc.), clcensunge I. 44, clcensas VII. 19 etc. (5); dcelde1 VI. 41 etc. (7), (v. §§ 132. II, 133. II); faeme J IX. 18, 20; halde Pref. 3 . XIV etc. (10), (v. § 132. II etc.), hoelend (sb.)

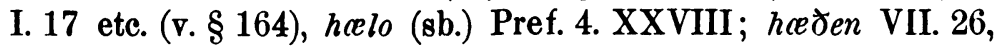
X. 33, 42, XIII. 10; hucem IV. 30, Pref. 1. 8, 5. 16; hrcete IV. 28; ladde VI. 17 etc. (17), (v. § 132. II etc.); -yelaefed VIII. 8, XII. 19, 22; lora IV. 1, II. 13 etc. (20), (v. §§ 113. 2, 115. 2 etc.); loes IV. 12, 31, IX. 42, Pref. 5. XLIV (leasse XV. 40, with ea miswritten for $\propto(a p$ ) cf. L. $\S 10$, anm., cf. teaslicor $\S 4$ j); mansumia XII. 25 (2), gemanelicum VII. 2; maniende V. 38, VIII. 12; gemcero VI. 36 etc. (6), (v. § 145. I, III); -ræes IV. 37, V. 13 (v. Z. $\S 14$. 2 , but C. $\S 57$. gives onrces under Gmc. $\hat{e}$ ); sce I. 16 etc. (14), accented (3), (v. § 148); stcenne XIV. 3, Pref. 5. XLIV, stcenero (petrosa) IV. 5, 16 (v. § 86); батm I. 9 etc. (ðam I. 20), ðıera (gen. pl.) VIII. 15 etc. (6), (ðara (12) v. § 39. 2), خare (f. sg.) VII. 25 etc. (v. § 182); tuœm V. 13 etc. (5), (v. $\S 178)$; wræððо III. 5, 21, wurceðia X. 41.

ea for $a$ occurs in toscecende V. 4 (

2) The forms with ae are: ae-laruas VIII. 11, X. 2; aehto X. 22; aenig IX. 30; aer XIV. 72; unreht-haemedo VII. 21; haedno Pref. 4. XXXIII; haelo Pref. 3. XVI; laeddon VII. 32, X. 11, Pref. 4. XXVII; laerde X. 1; maenendum XVI. 10; raesdon III. 10; sae IV. 39, VI. 49, VII. 31, XI. 23.

843. 1) $\hat{a}=i$-umlaut of $\hat{a}$ (v. $\S 40$ WS. $g \hat{a} n$ ) in : gce I. 38 etc. (3), with ae (5), (v. $\S 141$, cf. L. $\S 16.2$, Z. $\S 14.1$ ).

1 The glosses to-doela (discumbere) VIII. 6, and to-doeldon (discubuerunt VI. 40 must be due to some misreading of the Latin. cf. gesnita (accumbere) VI. 39 (v. §51.1, Note). 
2) $\hat{a}=\hat{e} a$ influenced by a following palatal consonant in: aec XV. 14, 21 etc. (17), accented VIII. 28 (beside ec (13), v. $\S 61)$; бœh XI. 26 etc. etc. v. $\$ 61$.

3) $\hat{e}$ is the result of contraction in: ic terhsla XIV. 27 etc. (v. $§ 129$ ); tuces (haesitauerit) XI. 23 (v. S. $\S 414$, anm. 4); and of compensation lengthening of $\alpha$ after loss of $g$ in: maden V. 39, 40, with ae V. 40, Pref. 3. XIV (beside magden (7) v. $\S 3.2)$.

4) $\hat{a}$ is of Scand. origin in: trael X. 44, XIII. 34, XIV.47, with ae XII. 4 (v. L. $\S 16$, anm.).

5) $\hat{e}$ for WS. $\hat{a}$ (= Gmc. $a i)$ occurs without any apparent reason in: wae (uae) XIII. 17, XIV. 21, XV. 29 unless it can be due to scribal confusion with the Latin vowel, as in: medo (medios) VII. 31 (v. § 7.2); diables (diaboli) Pref. 1.12 (v. § 64 3). But v. Kluge P. G. I. p. 787 “* wei geschrieben wae Durh.B. an. vei".

6) For $\hat{\alpha}(=$ Gmc. $\hat{x})$ beside the more frequent $\hat{e}$ v. $§ 44.3$.

$\hat{e}$.

8 44. Gme. $\hat{a}$, which in WS. remains unchanged, is as a rule represented by $\hat{e}$, but $\hat{e}$ occurs in a few instances ( $\nabla$. Sw. H. E. S. $\S \S 448,449$, ef. L. $\S 17)$. This $\hat{e}$ occurs:

$1)$ in the $2^{\text {nd }}$ pers. sg. and the plur. Pret. Indic., and in the whole Pret. Subj. of st. vbs. of Cl. IV, V (v. $§ \S 127$. III, 128. III): bedon VI. 56 ete. (5); brecon (manducauerunt) VI. 44 (from brecan in the sense of 'to break bread'? Or from bracan with the strong grade viwcl carried over to the plural v. gebrêc manducauit II. $26 \S 61$ ? v. B-T. gebrâcan, gebrêcon (manducauerunt) Lind. Jv. VI. 58, XVIII. 28); cuedon I. 30 ete. (7), (beside cuoede (41) v. $\$ 34$ ); dedon III. 6, VI. 12 (beside dydon (4) v. § 141); eton IV. 4 etc. (6), accented (2); frelton (comederunt) IV. 4 (v. $\S 103$ ); on-geton VI. 33, 38, 54; gesegon II. 12 etc. (22); setton (sedebant) III. 34 ; tredon (sternebant) XI. 8 (Rushw. has stredun from stregdan v. B-T.); -tredon III. 9; were I. 45 etc. (57), (beside were (4) v. below; woere (26) v. $\$ \S 34,138$ ); and in Pres. forms and Past Parts. of reduplicating verbs (v. $\S 130$. I, III): ondrede V. 36, VI. 50, XIII. 7; leta I. 34 etc. (28); redes XIII. 14, rêdes Pref. 1. 7 ; slepað XIV. 41 etc. (10).

2) Other words: bere (grauatum) II. 9, VI. 55, accented II. 4, 11, 12; efern I. 32 etc. (8), (v. $\S 86)$ : erenwreca Pref. $2 . \mathrm{V}$ 
(but v. S. Nachtr. $§ 100$ " $\hat{c}$ rende aus *aryndi" with $i$-umlaut of the first syllable); erest (resurrectionem) XII. 18 etc. (6) (v. $\S 148$ ); espryngc (fons) V. 29 ( (sb.) VI. 31 (cf. C. $\S 22$-stems "oferêt 0 -st.?"); feer- V. 42, XIII. 36; herum I. 6; huer XIV. 9, accented IX. 18, XV. 47; forletnisse Pref. 3. XX; behleing (proditione) Pref. 5. XLIV (= belewing with loss of $w$, and introduction of inorganic $h$ ? v. $\S \S 82$. I, 101 a); megnlillice Pref. 4. XXX; nedles X. 25; nedró XVI. 18 (v. §38.5); reda (lectionum) Pref. 2, 7, rêdes Pref. 1. 5; setnerum XV. 7, setnong XV. 7, gesetnade VI. 19; sprecum XVI. 17, accented (3); strêt IV. 4; خer II. 4, 6, IV. 5, 15 etc.

$o e$ is written for $e$ in honcroed XIII. 35.

3) $\hat{e}$ remains in: aet II. 16; woeron V. 13, VI. 54, XV. 42, XVI. 11 (beside weron (57) etc. v. (1) above); eghuar XVI. 20 (beside huer (3); suce I. 2, 22 etc. (23), (beside swa (44) v. §41. 1). The form se in tah se, бah se (quodsi) VI. 23, IX. 50, XI. 26 is probably a weakened form of swa. Jeah swa $=$ swa ¿eah.

Note. For hat (imperat) Pref. 3. XXV. v. $\$ 107$.

85. The $i$-nmlaut of Gmc. $\hat{e}(\S 44)$ is also represented by $\hat{e}$.

The examples are: dêd Pref. 2.5; lece II. 17, V. 26, lecnade I. 34 (v. C. §63), (leicnung Pref. 2. VI, v. § 63. 1); beleede (proderet) XIV. 10 (v. S. $\S 174.3$ and anm. 3); woegena geletum (biuio) XI. 4; megða VIII. 10; mersiga I. 45, III. 12, mersung I. 28, XIII. 7; merठu I. 28; sed XII. 19 etc. (4), accented (2), sedere IV. 3, 26; telað (accusant) Pref. 3. XX etc. (9), (v. §§ 132. II, 133. II etc.), telnisse IV. 19 (v. C. $\$ 63$ ); genedo V. 30 (beside gewoede (2) v. § 34.1 ).

oe occurs in soel (bene) XVI. 18 (v. C. $\S 65$ ).

ea occurs in teaslicor (oportune) XIV. 11 (cf. leasse $\$ 42.1$ ); and $a$ in auceled (uexatus) V. 18 (cf. Brown, $\S 43$ c, v. C.N. 142 "auceled alt. from aucelled").

8 46. 1) $\hat{e}=$ Goth. $\hat{e}$ OHG. $e a$, $i a$ (v. Z. § 15. 2, "Ein $\hat{e}$, dessen ursprung noch dunkel ist") in: her VI. 3 etc. (5), hér VIII. 4 (hir XVI.6).

2) $\hat{e}$ is the result of contraction in: teno X. 41 (v.S. $\$ 113$ ); gesee (uideamus) XV. 32 (cf. L. $\S 17.3$ ); swer (socrus) I. 30 (swoer Pref. 2. V); and in the reduplicated Pret. forms (v. §130): 
-feng VII. 34 etc. (11), onfence, onfenge VI. 41, XVI. 19 (cf. L. $\S 50$, anm. "wahrscheinlich formen eines adj."); hengon XV. $20,24,25,27$.

3) For the $\hat{e}$ in: $\hat{e} c e$ (aeterni) III. 29, X. 17, 30, ecnisse III. 29, XI. 14 (ace IX. 45) v. C. $\S 12$, L. $\S 17.4$.

For $\hat{e}$ in tuege (duo) Pref. 5. XLI etc. (3), (v. $\S 178$ ), v. Kluge, P. G. $\S 602$, p. 403 , cf. Brown $\S 50$ (beside Iwoege, v. §34. 2).

4) $\hat{e}=i$-umlaut of $\hat{a}$ (from Gmc. ai) in: eghwelc, eghuar etc. IX. 15 , XVI. 20 etc. (7), (aghuelc XIV. 49. v. C. $\S 88$ ); geneolecde I. 15 etc. (11), (v. 132. III).

For enne (unum) IV. 8, VIII. 28, XII. 6, XV. 6 with a short vowel v. S. $\S 324$. 1 .

5) $\hat{e}$ is due to lengthening of final $e$ in monosyllables (v. S. $\S 121$ ) in: he I. 8, II. 12 etc., hee X. 6 , me II. 14 etc., ne I. 22, 34, II. 19 etc., se I. 17, 25 etc. (sa X. 24), خe (tibi) I. 24 etc. ðe (Dem.) I. 12, III. 7 etc. (бœ XIV. 60), we II. 12 etc. (wae IV. 35 , woe IX. 28 etc. (5), (v. $\S \S 181,182)$.

6) For $\hat{e}$ in gêe, gêt $v$. $\S 28$. For $\hat{e}=i$-umlaut of $\hat{e} a$ and êo before palatals v. $\S 61$.

$\hat{0}$.

84. $\hat{o}(=$ Gmc. $\hat{o})$ occurs regularly in:

1) the Pret. Indic. and Subj. of st. vbs. Cl. VI. (v. § 129. II, III): -hlogan V. 40; ahof I. 31, IX. 27; slog XIV. 74 etc. (9); on-soc Pref. 3. XXIV, accented (4); stod X. 49, XIV. 70, XV. 39 ; swor VI. 23; ge $\delta$ ıgon VII. 3; gewoxe XII. 44.

2) Other words : boc XII. 26, XVI. end, accented (2); blodes V. 25 etc. (4), accented XIV. 12 ; broðer I. 16 etc. (21), (v. § 163); doa X. 17 etc. (25), (v. $\S \S 50.1,140$ ); dogor VIII. 2, XIV. 1, 58; -dom VII. 22 etc. (3), accented X. 42, XII. 40 ; fota XII. 36 etc. (5), accented IX. 45 (v. § 166. I); god IV. 20, IX. 42, 43, 47 etc. accented X. 51; behoflic XI. 3; hrof XIII. 15, 27; locade VI. 41 etc. (6), (v. § 134. 1); -môd X. 49, eðmodigað I. 27, IV. 41; moder III. 31 etc. (15), (v. $\S 163)$; mor III. 13, V. 11, IX. 2,9 etc., accented VI. 46 , XI. 23 ; $\hat{\text { or }}$ (initium) XIII. 8 ; rode XV. 30,32 ; unrotsia XIV. 19 etc. (5), accented (2), (v. § 95); ronincg VI.48; gescoed VI. 9 (v. §135.2, Note); sohte XIV. 11 etc. (9), (v. §§ 132. III, 133. III); -stow VII. 4 etc. (7), (v. $\$ 146$ etc.); Jrouenda V. 26 etc. (3), Jrowungo V. 26 etc. (4), (v. § 82. I. 3), lîcðrower I. 40, 
Pref. 2. VI; to I. 5, IV. 38, VII. 1 etc., accented II. 13; wodnes doige Pref. 5.10 ; wopendum XVI. 10 (beside woepa etc. v. $\$ 50$ 1); wroht (sb.) XIII. 14.

Loan-words: non XV. 33 (v. Pog. $\S \S 175,176)$. The $\hat{o}$ in sônum Pref. 1.9 is lengthened from $o$ (v. Pog. $\$ 150)$, cf. stol $\$ 9.2$.

$\S$ 48. $\hat{o}(=$ Gmc. $\hat{a}$ before Nasals v. S. $\S 68$ ) occurs regularly in: cuom, cuomon I. 38, II. 2 etc. (82), (v. § 127); huon I. 19, VI. 5. 31 etc. (6); mona XIII. 24; -nom, nomon V. 40, VIII. 2 etc. (14), (v. § 127); sona I. 10, 12, 30, 43 etc., sôna I. 42.

$\S 49.1) \hat{o}$ is the result of lengthening of $o$ after the loss of a nasal:

a) before the voiceless spirants $f, \gamma$, and $s$ (v. S. $\S 186.1$ ) in: ozer II. 21 , IV. 4,8 , VI. 15 , XII. 4 etc. (v. $§ 76$. II); so ${ }^{1}$ (at) III. 4, VI. 49, VII. 6 etc.; soð $a$, so ð $a$ (deinde) IV. 17, 28, Pref. 1. 15, 2. 4; soð̌est V. 33, soð- VI. 35, VIII. 2, 9, 12, XII. 14 etc.; toðum IX. 18.

The vowel is short owing to want of accent in: oðd XIV. 25, 34, Pref. 4. XXVII, оððe XI. 30, XII. 14, обð aet IX. 1 etc. (5), (v. § 104, ef. S. § 186, anm. 3).

b) before $h$ (v. S. $\S 67$ ) in : brohte X. 14 etc. (14), (v. $\S \S 132$, III, 133. III); gefoanne, -foas etc. XIV. 22,48 etc. (16), (v. $\$ 130$, v. S. § 374, anm. "fóeð (fáð?)". For -foeð sg. v. § 50. 3); ahoa XV. 20 etc. (4), (v. $\S 130)$; Johtes (sb.) V. 15, XII. 30, 万ohton (vb.) II. 8, VIII. 16, 18; wohfullum XV. 28.

2) $\hat{o}$ corresponds to Gmc. ai (v. C. $\S 87$, cf. Bruwn $\S 57$ ) in : no XI. 14, XII. 14, oht, noht XV. 24 etc. (6), (v. § 186).

For $\hat{o}$ in hônd, lônd etc. v. $\S 38(4)$.

Note. $\hat{o}$ stands for $\hat{e} o$ in rode (calamo) XV. $36=$ hreode, cf. hreade (harundine) XV. 19, v. H. Note 44, p. 29. For the loss of initial $h$ v. $\$ 101.2$.

$\S 50$. The $i$-umlaut of $\hat{o}(\S \S 47,48,49.1)$ is oe (v. Sw. H. E. S. $\S 488,489$ ). Only two instances of $\hat{e}$ occur. In a few cases oe occurs where the corresponding word in WS. has no umlaut, the umlauted vowel having been here carried over from forms where it is regular. The examples are:

1) oe $i$-umlant of $\hat{o}=$ Gmc. $\hat{o}$ in: gebloedsade VI. 41 etc. (7), (v. § 134 etc.); boecere (scribæ) Pref. 5. XL (cf.bôecere (sg.) Jn. XIX. 37 margin. WS. bôcere); eft-boete (restitutio) Pref. 2. VIII (with the vowel carried over from the verb. WS. bôt (sb.),

1 In the gloss cuoed him $l$ sod (ait) XI. 31 sog is perhaps due to the scribe's confusion of the Latin words ait and at. Being uncertain which he had before him he gave the translation of both, cf. $\oint 104.2$, Note. 
bêtan (vb.), eft-boeleng Pref. 2. VIII, geboetad III. 5, IX. 12; broe $r$ re (dat. sg.) XII. 19; doe (subj.), does etc. XI. 28, 29 ete. (v. § 140, S. § 429, anm. 2 „Bei den nichtwests. formen mit oe ist es zweifelhaft, ob dieselben mit $\dot{b} e$ oder $\dot{a}$ anzusetzen sind, da die hss. nicht unterscheiden"); doeg X. 34 etc. (10), (v. § 165); gedroefde IX. 20; foedende V. 11, 14, VII. 27, XIII. 17; gefoelde V. 29 ; foet (acc. pl.) IX. 45; foèemenn VI. 33; foerende, foerde I. 5, Pref. 3. XIV etc. (45), (v. § 132. II); groene VI. 39 ; groeteng (salutationum) Pref. 5. XL, groeton IX. 15, XII. 38, XV. 18; eorठ hroernis XIII. 8; moeder (dat. sg.) VI. 24, VII. 11, 12 ; gemoetat IV. 19, XIV. 16, gemoetingum XIII. 9; oefeste (festinatione) VI. 25 (generally in WS. ôfost, offest, ôfst (sb.), êfstan (vb.)); oeঠel VI. 1, 4, Pref. 3. XV; -geroefum XIII. 9, XV. 4, 5 (but v. C. §16); scôe (calciamentorum) I. 7 (v. S. § 242, anm. 2 North. gen. pl. scá); gesoeca VIII. 11 etc. (12), accented (2), (v. §§ 111.2, 113. 2 etc.); unspoed XII. 44; woepende V. 38 (beside wopendum XVI. 10), woepa XIV. 72 (v. C.N. 144 "weopa alt. to --"); woestern I. $3,4,12,13$, VIII. 4 , woestig VI. 31 etc. (4).

$\hat{e}$ only occurs in: gebledsade X. 16 (beside bloedsade (7)); ne reces $\partial u$ (pertinet) IV. 38.

2) oe $i$-umlaut of $\hat{o}=$ Gmc. $\hat{e}$ before Nasals in: mara woen (alio quin) II. 22, un-woen VI. 14, woenes (vb.) IV. 41, VI. 49, woeno (sb.) XIII. 7, woen- XI. 13, XIV. 2, 56, accented XIV. 59.

3) oe $i$-umlant of $\hat{o}$ from on, older an in: onfoed VI. 11 etc. (v. $\S \$ 49$ a, 130, ef. doe $(1)$ above); gehoen XV. 15, 32, XVI. 6; oehtendum X. 30, oehtrise IV. 17, Pref. 4. XXXII.

No te. $i$ appears in $a f i s t$ (inuidiam) XV.10, v. S. $\S 43$ naus * $c e f-e ̂ s \iota^{\mu}$, and Nachtr. " ${ }^{*}$ of -unsti".

$\hat{\imath}$.

§ 51. $\hat{\imath}(=$ Gmc. $\hat{\imath})$ occurs regularly in:

1) Pres. forms of st. vbs. Cl. I. (v. $\S 124)$ : bidas XV. 36 etc. (3); gebites IX. 18 (2), bidtende I. 26 (v. § 38. 3); -drifa III. 23 etc. (4); gegripes IX. 18; hrina III. 10, V. 28, accented I. 41 (gehrinde VIII. 22, -hrindon III. 10, weak Pret. forms, ef. Matt. XIV. 36); -rises (debet) XIII. 10, 14 ; aris II. 11 etc. (14), accented (4), (eft arisa, -e (resurrexerit) IX. 9,10 v. $\$ 124$. I); scinendo IX. 3 ; slitas VII. 13 etc. (5). gesnið $a^{1}$ (accumbere) VI. 39;

1 B-T. quotes this as a separate verb from gesnì it seems more probable that it is simply one of the cases where the scribe has wisread the Latin (v. Bout. p. ciii), cf. $\S 42$, Note. discumbere glossed by to-dcela.

Anglie. N. F. IV. 
stigende IV. 8 etc. (8), (astigedon VI. 32 v. § 90. 3); gesuicanne XIII. 22 etc. (3); wriga (uelare) XIV. 65 (v. S. $§ 383$ and anm. 2).

2) other words: fic- XI. 13 etc. (6); gitsungas VI. 28; huil V. 3 etc. (9); huit IX. 3 etc. (5); idilnisse VII. 7, XII. 3; -isern IV. 21, 29; lichoma V. 29 etc. (14), (v. § 156), licðrower Pref. 2. VI, lîc- I. 40; licade I. 11 etc. (3), accented Pref. 4. XXXIII; gelic XII. 21 etc. (9), accented (5); lif IX. 43,45 etc. (5); accented X. 30 ; liñ XV. 46 (2); $\min$ I. 2 , III. 33,35 etc. (v. § 181), accented (3); ric IV. 30 etc. (6), accented (16); rip-isern IV. 29 ; scinisse XIII. 24; sîdo I. 6 ; stiga (semitas) I. 3; astignise Pref. 5. XLVI; swigdon I. 22 etc. (10), (v. § 136. 6, S. § 416, anm. 8. "Anglisch swîgian (swigian?)"), feer-suigo V. 42; tid VI. 35 etc. (5), accented (17); Jin I. 2, 44, VII. 29 etc. (v. § 181); бrim VI.

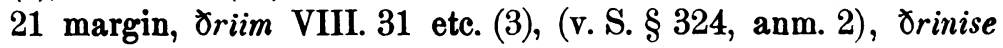
Pref. 2. II, $\partial$ rittig IV. 8,20 (v. S. $\S 230$, anm.); wif V. 25, 33, VII. 25, 26 etc.; win II. 22 etc. (10); wislice XII. 34, unwisdom VII. 22; unreht-uisum XV. 28; wilge (sb.) VI. 4 etc. (8), (v. $\S \S 156$, 157), gevitgade VII. 6 , XIV. 65 ; wiðlað VII. 23 etc. (6), (v. § 97. 2).

Loan-word: crist VIII. 29 etc. (10), (v. § 167).

Note. The vowel of the following verb is given as $x$ in BosworthToller, but Professor Sievers regards it as $\hat{\imath}, \nabla$. his explanation below. The forms which occur are: giuar (petitis) XI. 24, Ja giuendo (postulata) Pref. 4. XXXVI, giuwende Pref. 4. XXXIII, ic giuge walle VI. 24, giuig (Imp.) VI. 22, giude Pref. 4. XXXIV, giuede XV. 43, gegiuas VI: 23, gewiged X. 38, gegiuudon XV. 6.

ngivian does not seem to have any exact parallel in the other Germanic languages. But the almost constant spelling with a simple $i$ before the $w$ (there are only a few isolated io's) seems to show that the $i$ was long. The preterite gîude points to the ai-class, so that we probably shall have to start from a stem givai-, possibly givooja-, if the inflection after the ai-class should be secondary.

This $g \hat{i}-w a i$, or $g \hat{i}-w \hat{o}-j a$ I am inclined to take for a derivation from the root $g \hat{\imath}$, which in a reduplicated form appears in Goth. gei-gan, pret. gei-gai-da (cf. the parallels of rei-ra-n, rei-rai-da, also Germ. bî-bên, $0 \mathrm{E}$. bîfian along with błbên, błfian from orig. bhi-bhai, also OHG. zillarôn from ti-tro; also cp. Goth. derivation -gcigo in faihugeigo and reiro, which show that there was no feeling left for the reduplicated character of such formations as geigan, reiran).

It is difficult to make out the exact relation between geigan and OE. givian. 'I'hey do not seem to be absolutely identical. There is no direct way of connecting the $\mathrm{OE}$. $w$ with the Goth. $g$, for the analogy of the later WS. survian for swigian does not hold good, as this transition of $g$ into $w$ is distinctly later and Southern. So perhaps it would be 
better to assume a wo-derivation: gî-wo- against gei-gai. If we furthermore assume that the root gei in gei-gai, gîno 'desire' is ultimately the same as the root ghei in Lat. hi-are etc. (the change of meaning could I suppose be explained: 'to snap at, to open one's month for' would I suppose be the turning point), we could find a parallel to the $g \hat{\imath}-w o$ - formation in OHG. givên, gî̀n 'to gape'."

5 52. 1) $\hat{\imath}$ is the result of lengthening of $i$ after the loss of a nasal before a voiceless spirant (v. S. $\$ 186.1$ ) in: fif VI. 38 etc. (7), (v. $§ 178$ ); siðo X. 30, XIV. 41, Pref. 4. XXXII; stiðnise XVI. 14; suiðe I. 3j, III. 12 etc. (23), (จ. § 177), swiðra (sb.) X. 40 etc. (8), (v. $\S 175$. I).

Loan-word: pislico (ingrauati) XIV. 40 (v. Pog. § 131).

2) $\hat{\imath}$ is the result of contraction (v. $\$ 64)$ in: frige doeg Pref. 5. 17, gefrigade (complexans) X. 16, friende IX. 36 (v. S. $\$ 416$, anm. 5); ic gesii X. 51 etc. (4), (v. § 128); swira V. 1, IX. 42; getuiga (haesitauerit) XI. 23 (v. S. $\S 414$, anm. 4).

3) $\hat{\imath}$ is due to lengthening of final $i$ in monosyllables in: bi X. 11, XII. 35; bismerlice VII. 9, X. 34, XV. 20, 31; bispell IV. 10 etc. (13), v. bi-Prefix $\S 74$. II).

4) For $\hat{\imath}$ in nîve etc. $\nabla . \S 62$. For $\hat{\imath}$ in blind v. $\S 38$. 4 .

Note. hi X. 38 is a scribal error for hu v. C.N. 143. For $\hat{\imath}$ in gehrino XIII. 2 , v. $\S 23$, Note.

$\hat{u}$.

5 53. $\hat{u}(=$ Gme. $\hat{u})$ occurs in:

1) Pres. forms of certain st. vbs. belonging to $\mathrm{Cl}$. II (v. $\S$ 125. I, S. § 385): brucanne VI. 37 etc. (3), accented (2); -hlutende I. 7 (with inorganic $h$ v. $\S 101.1$ ); gesupedon Pref. 4. XXVII (=gesupende? จ. $\$ 90.3$ ).

2) other words: buendo XII. 7 etc. (4), (v. $\$ 130)$; gedrugade IV. 6 , V. 29 , XI. 21 (drygas VI. 11, v. $\$ 55.1$ ); adune II. 4, XIII. 3,15, XV. 30, 32; hus II. 1, 4 etc. (28), accented (2); runlice Pref. 5. XLIV; Jusend Pref. 3. XVIII etc. (8), (v. § 178); fellun VII. 19 (v. S. $\S 231.3$ ); ut-, uta, buta I. 45 , XI. 15 etc. (28), (v. $\S 176.6$, accented (3).

5 54. 1) $\hat{u}$ is the result of lengthening of $u$ after the loss of a nasal before a voiceless spirant (v. S. $\$ 186.1$ ) in : cuðon IX. 32, uncuð III. 10; muðum VII. 6; uhte XIII. 35 (v. S. $\S 186$, anm. 4); us, usic etc. I. 24, V. 12 etc. ( $\nabla . \$ 181$ ), accented I. 24 , wusig XI. 9 (v. $\S 80$ ); uð-uuto VII. 5 etc. (7), иuð- (6), wu (8) (v. $\$ \$ 38.2,80$ ). 
2) $a$ is due to lengthening of final $u$ in monosyllables (v. S. $\S 121$ ) in: $n u$ V. 36, X. 30, XIII. 19, accented XV. 32; $u$ I. $11,24,40,44$ etc.

3) For $a$ in: $h u$ VI. 38, XV. 4, huu II. 26 etc. (20), hulic V. 16, hulco XIII. 1 (v. S. § 342) huulig XIII. 1 ; tıu (duo) XV. 38 , v. S. $\S 172$, anm.

For $\hat{u}$ in: $a n$-, suundorlice ete. $\mathbf{v}$ § 38. 4 .

655. The $i$-umlaut of $\hat{u}(\nabla . \S \S 53,54.1)$ is, as a rule, $\hat{y}$. This $\hat{y}$ is in one instance written $u i$, and $\hat{\imath}$ for $\hat{y}$ occurs in the word bissen. The examples are:

1) $i$-umlant of $\hat{u}=$ Gme. $\hat{a}: b y$ (domicilium) V. 3, bya (vb.) IV. 32, VI. 35 (beside buend v. $§ \S 53.2,130$ ); drygi (adj.) III. 1, 3, Pref. 2. VIII, drygas (vb.) VI. 11 (beside -drugade (3), v. §53. 2); fystum XIV. 65 (2); gehyda XIV. 65; untyndo I. 10, VII. 35, VIII. 34. The vowel is long (v. Sievers P. B. B. X. p. 504) in: lytel I. 19 etc. (8), (v. $\S \S 76 . I, 79)$.

$u i$ occurs in: druige (aridam) XI. 20 (cf. $u i$ for $\breve{y} \S 27.4$ ).

2) $i$-umlant of $a$ from un:-cyðed Pref. 1. 16, 5. XL, cyðnise XIII. 9 etc. (12), cyðठo VI. $4 ; \hat{y} \delta$ IV. 37 ; yrte (procella) IV. 37 (v. C.N. 142 "probably for yste").

3) $\hat{\imath}$ for $\hat{y}$ occurs in: bissen, bisene VII. 17 etc. (4), (v. $\S \S 151$, 152), gebis (imitandos) Pref. 4 . XXXIII (v. C. $\S 51$ ).

4) For $\hat{y}$ in: fyr IX. 22 etc. (9), v. C. $\S 107$.

\section{Chapter III. Diphthongs.}

$\hat{e} a$.

5 56. $\hat{e} a$ (= Gmc. au and WGmc. au before a following $w$, in Goth. aggw v. S. § 63) occurs regularly, with the exception of a very few cases where $\hat{e} o$ is written for $\hat{e} a$ (cf. the interchange of $e o$ and $e a \S \S 13,16$. For $\hat{e} a$ before a palatal consonant $\nabla . \S 61)$. $\hat{e} a$ occurs in :

1) the $1^{\text {st }}$ and $3^{\text {rd }}$ pers. sg. of the Pret. Indic. of st. vbs. Cl. II. (v. § 125. II): bead Pref. 4. XVIII etc. (14), (forbeades prohiberi Pref. 4. XXX?); geceas XIII. 20; -leat II. 12, V. 22; and the Redup. Past Part. geheawen XV. 46 (v. C. $\S 92$ ). For spenft (expuens) VIII. 23, speafton XV. 19, v. S. $\S 384$, anm. 5.

In agaett (effudit) XIV. 3 ae is apparently an error for $e a$. (Perhaps due to confusion with ongat, -gaet $\S 3.1$ ?).

2) other words: -beam XI. 13, 20 etc. (9), (v. § 143 II. etc.): ceapas VI. 36, ceapemen XI. 15; dead V. 35, 39 etc. (15), deaঠ 
IX. 1 ete. (8), (v. $\S \S 153$. II); deaf VII. 32, IX. 25, Pref. 3. XXII; Eadfrið Pref. 1, heading; earo IV. 9 etc. (7), (v. § 162); eastro XIV. 1 etc. (5), (v. $\S 161)$; caða XI. 13 etc. (6); ced-eauad IV. 22 etc. (15), (v. $\S \S 132$. II, 133. II etc.), eauung IV. 22 etc. (3), -eannise Pref. 3. XI (v. §80. I, enunga I. 45, aevades III. 12, v. $\S 62$ ); heafod XV. 19 etc. (10), (v. §66); leafo (folia) XI. 13; geleafa IV. 40 etc. (8), (v. § 156), -geleaffull IX. 19 etc. (7); leas X. 19 etc. (5); felle reade XV. 17, 20 (v. $\$ 4$ Note); reafad III. 27, XV. 20 (v. $\$ 101.1$ ); sceaude X. 27 etc, (6), (v. §§ 111. 3, 134. 1, 3, -scewde v. $\S 62)$, sceawung XII. 40; screadunga VI. 43 etc. (5); seað XII. 1 ; smeadon II. 8 etc. (5), (v. § 136. 4), smeaungas VII. 21 (v. S. § 119); stream I. 5 ; team XII. 21, accented XII. 22; ðeah III. 26 (ðah, doh v. 61. 1); Jreat IV. 1 etc. (17), accented (3), (v. § 95); geðreað Pret. 5. XLVI etc. (4), (v. § 136. 4); geðreadlaige VIII. 32, Pref. 2. VIII, 3. XX, 4. XXVI.

3) êo for êa occurs in: deofo VII. 37 (beside deaf (3); eostro XIV. 12, Pref. 5. 18 (beside eastro (5); gleoulice VIII. 25, gleonnise III. 5; heofud VI. 25 (beside heafud (10); gereofa ge III. 27 (= gereofage (Inf.) beside reafað (2).

$\S$ 57. The $i$-umlaut of $\hat{e} a$ is $\hat{e}$ (v. S. $\S 159.3$ ). For $e i$ before palatal consonants, v. $\S 63.1$.

The examples of $\hat{e}$ are; beged X. 17, -beging I. 40; ceping Pref. 2. VII; degle IV. 22 (2), IX. 28; gedeðed (moriatur) VII. 10 ; geeced (adicietur) IV. 24; an-êge (adj.) IX. 47; eðelico X. 27, XII. 40 (beside -eaðalice Pref. 4. XXXII), eðmodigað I. 27, $\hat{e} d$ - IV. 21 ; gegemde III. 2 etc. (5), accented I. 34, gemnisses III. 15; henбu XII. 44, gehened XVI. 16 etc. (4), accented IX. 12; hêra (minister) X. 43, heranne IV. 9 etc. (51), accented (2), (v. $\S 132$. II etc.), hersumiað IV. 41, Pref. 4. XXXIII, hernise ${ }^{1}$ IV. 11, 23, Pref. 1. 13; hremas V. 39; lefde (sinebat) I. 34 etc. (9), accented (2), (v. § 133, II etc.); gelef (crede) V. 36 etc. (20); lesinc (redemtionem) X. 45, lesnise X. 45, alesde Pref. 1. 14; ned II. 25, geneddon XV. 21 .

\section{$\hat{e} 0$.}

5 58. $\hat{e} o$ (= Gmc. eu, and WGmc. eu before a following $w$, in Goth. iggn, v. S. $\S 64)$ occurs as $\hat{e} o$ and $\hat{\imath} o$. The occurrence of $\hat{e} a$ for $\hat{e} o$ is commoner than that of $\hat{e} o$ for $\hat{e} a$ (v. $\S 56$. 3 , cf. L. $\S 22$. II, anm. For $\hat{e} o$ before a palatal consonant v.

1 In IV. 11 hernise is the gloss to misterium, which latter word the scribe has apparently mistaken for ministerium, v. Pref. 1.13. 
$\S 61.2$, and for the influence of a following $w$ v. $\S 62)$. The examples are:

1) $\hat{e} o:$ a) in the Pres. forms of st. vbs. Cl. II: -beodend Pref. 4.XXXI; WS. lêoran is conjugated as a wk. vb. (v. S. § 384, anm. 3): bi-lenre (transfer) XIV. 36, -leorade XIV. 35.

b) other words : beom V. 28 etc. (5), (v. § 138); deoplice Pref. 5. XLIV; cneoreso VIII. 12, 38, XIII. 30, cneoureso VIII. 12 (cnewreso IX. 19, v. § 62); deorum I. 13, Pref. 1. 12; feower VIII. 9 etc. (9), (v. $§ 82.5)$; hreowigas I. 15, hreownisses I. 4; leofuste IX. 7, XII. 6; geleornise XIV. 28, XVI. 7; reof (leprosus) Pref. 2. VI; Jeod- VIII. 12, Pref. 2. 3.

2) io occurs in: geliored XIII. 30 etc. (5), (v. §§ 101.1, 125. I); biom V. 28 (beside beom (5); diorwyrdes XIV. 3; iowh III. 28 etc. (4), (v. $§ 181$. II, iuh $\S 62$ ); riofol (lepra) I. 42, (beside reof (1); onsione I. 2, XII. 14, XIV. 65; stiorde VIII. 30, 33 etc. (7); strionendra Pref. 3. XX; gestriona (lucretur) VIII. 36, gestrion (sb.) X. 21, 23, 24; ellðiodade XIII. 34 (beside teod (2); jiofunta VII. 22, forðiofe (fureris) X. 19; Jiostrig VIII. 17, Jiostro XV. 33, ge-ठiostrod XIII. 24 (-geðistrat VI. 52 v. § 60); jionum XIV. 66 (Jiwa v. $\$ 62$ ).

3) $\hat{e} a$ for $\hat{e} o$ occurs in: -beada IX. 39 etc. (4), (beside -beodend (1) v. § 125. I); bead (mensa) VII. 28, XI. 15; gebear (conuiuio) Pref. 2. VII; dear (sb.) X. 25 margin (beside deor (2); fearda VI. 48 (beside feorठ $a$ etc. (9); hreade (harundine) XV. 19 (rode calamo XV. 36, v. $\S 49$, Note), hreafes XIV. 3 (beside reof (1), riofol (1); hreawnisse VI. 12 (beside hreow- (2); leaf I. 11, IX. 7, X. 24 (beside leof- (2); dea (seruus) Pref. 5. XLIII (beside Jionum (1); Jeafana XI. 17, XIV. 48 (beside Jiof (2).

4) For $a$ in: am VI. 50 etc. (5), v. Sw. H. E. S. $\S 442$.

5 59. $\hat{e} o(=\mathrm{WS} . \hat{e} 0$ ) in the Pret. forms êode, êodon, and $\hat{e} o$ in certain reduplicated Prets. (v. S. $\S 396$ ) frequently interchange with $\hat{e} a$.

1) $\hat{e} o$ occurs in: eode, eodon II. 26 , III. 6 etc. (46) (v. $\$ 141)$; and in: oncneon II. 8; feoll IV. 4 etc. (8), (v. § 130. II).

2) êa occurs in: eade, eadon VI. 35,37 etc. (10); and in: oncneawn VI. 38,52 ; gefeall V. 33; gefealde IX. 20 (= gefeald v. $§ 130 . \mathrm{II})$; -heald V. 41 etc. (15), (behoeald XII. 41); geseaw IV. 4. 
60. The $i$-umlaut of $\hat{e}_{0}$ only occurs in: gesene X. 42, XIV. 64, XVI. 11; and possibly in fore-geðistrat (obcecatum) VI. 52 (beside -ðiostrod XIII. 24), unless $i$ is here only a scribal error for io.

For strionendra, onsione etc. without i-umlaut v. $\S 58$.

\section{Palatal umlaut.}

6 61. $\hat{e} a$ and $\hat{e} o$ before $c, g, h$ are changed to $\hat{e}$ (v. S. $\S$ 163). Before $c$ and $h, \hat{e}$ occurs beside $\hat{e}$. The examples are:

1) $\hat{e}$ from $\hat{e} a:$ a) before $c$ : becon VIII. 11,12 etc. (8), (v. $\S 71.2)$; gebrêc I. 6 , II. 26 (v. S. § 385. 2); ec VII. 18 etc. (9), accented (4). (beside $a c$ (17), accented VIII. 28 v. § 43. 2). êa has undergone $i$-umlaut in geeced (adicietur) IV. 24 .

b) before $g$ : beg XV. 17 ; ego VII. 22 etc. (8), (v. § 162). êa has undergone $i$-umlaut in an-êge IX. 47.

c) before $h$ : heh XIV. 36 etc. (20), (v. § 102. 5); neh X. 46 , XIII. 28, 29, XIV. 42.

êa has undergone $i$-umlaut in: hera X. 43 (v. S. § 166. 5), nesta VI. 36, XVI. 14, neesta XII. 31, 33, nêesto I. 38.

$\hat{a}$ occurs in: fore-flach (profugit) XIV. 52; haeh XIV. 60 (beside heh (20); ataeh (educens) XIV. 47; jreh IX. 42 etc. (4), ðaeh VIII. 36 etc. (3), beside teah III. 26, ðah VI. 23, IX. 50). VII. 6 .

2) $\hat{e}$ from $\hat{e} o$ only in: flegendo IV. 4 ; legerum (hypocritis)

\section{Influence of a following $w$.}

6 62. The groups în, ên (from Gmc. eun, and from Gme. $i n$, ew) as a rule appear as in, and $e w$ (v. S. $\$ 156.5$ ), but iow, êo occurs in several instances (cf. L. $\$ \S 22$, IV. 28).

The examples are: iuih, iuh, iuer I. 17, II. 16, VI. 11 etc. (about (72) v. $\$ 181$ ), (beside ionh (4); gebleuu (expuens) VII. 33; oncnewa (Pret. Subj.) Pref. 2, 3, 4; feuer VIII. 20 (beside feower (4) and with loss of $n$, feor etc. (5) v. $\S 58.1$ ).

êow remains in: hreownisses I. 4, 15, VI. 12.

From original in, en (v. S. $\$ 73$, and for absence of $i$-umlaut v. L. $\S 28$ ) are: oferhiued IX. 2, -hivade Pref. 4. XXVII; niua I. 27 etc. (8), -niuad VIII. 25, niwunga XIV. 40; siuieð II. 21 ; Jiwa XIV. 69 (beside jionum XIV. 66, and ठea Pref. 5. XLIII. For larun = *lar-ðeon v. § 75); cnewa XV. 19 etc. (3), 
cnewreso IX. 19 (beside cneoureso VIII. 12, and cneoreso (3), v. §58. 1); treuo VIII. 24 etc. (3), (tree XII. 26, v. § 82. 6).

ew for êow occurs in: enunga I. 45 (beside ean- (19), aewades III. 12, v. § 56. 2. For êowan beside êavan v. Paul, P. B. B. VI, p. 97).

ew for êaw occurs in: -sceuade VIII. 24, sceware VI. 27 (beside sceaw- (7) cf. Z. § 19.1).

$e w$ for $a w$ (v. C. $\S 58.2$ ) in: cewlas (sportas) VIII. 8 (beside ceaulas VI. 43 , ceolas VIII. 20 , v. $\S 40)$.

$e i$ and $a i$.

6 63. The special North. diphthongs ei and $a i$ (v. S. $\S 155$. 3 , and L. $\S 23$ ) occur in the following instances:

1) $e i$ in: the verb ceiga X. 49 etc. (26), (v. $\S 132$. II etc.), ceigeng Pref. 2. III; fifteig- Pref. 5. 16 (beside fiftigum VI. 40, feortig etc. v. §178); heista V. 7; leicnung Pref. 2. VI (beside lece etc. $\mathrm{v} . \S 45$ ); seista XV. 33 (nesta always with $\hat{e}$ v. $\S 61.1$ ).

2) ai only in: gefraign VIII. 5 etc. (3), (beside gefrogn (5), gefregn (1) v. § 3), and in the wk. vb. gefraigne (Inf.) XII. 34 etc. (4), fraignung (sb.) Pref. 4. XXXVII (beside gefragndon etc. (3), gefregndon etc. (5), v. $\S \S 3.2,3,134.4$, v. Kluge P. G. p.786 "fregna, fregnde an. fregna, fregnde").

\section{Contraction.}

5 64. 1) WGmc. $a+o, u$ (v. S. $\S \S 111,166.1)$ is represented by $\hat{a}$ in: -slaa VI. 19 etc. (4), (v. $\S 129)$; $\hat{e} a$ occurs in : smeadon II. 8 etc., and treað Pref. 4. XXXIII etc. (v. § 56. 2, Paul, P. B. B. VI, p. 93).

Contraction has not taken place in eher (spica) IV. 28; teherum (lacrimis) IX. 24.

2) WGmc. $e+o, u$ (v. S. $\S 166.2)$ generally appears as $\hat{e} a$ : gefea (gratia) Pref. 3. XVI, gefeando XIV. 11; fleað (pl.) XIII. 14; sea, geseas X. 51, XIII. 26 etc. (23), (beside ic geseom VIII. 24, gesee (Subj. pl.) XV. 32, v. § 128); hunteantig X. 30 etc. (3), (v. $\S 178)$.

$e+e$ is $\hat{e}$ in teno X. 41 (v. S. $\S 113$ ).

3) WGmc. $i+o, u$ (v. S. $\S 114.1 .2)$ appears as $\hat{\imath}, e o, e a$, io, ia, iu. (For examples of $i$ v. $\S 52.2$.)

The examples are: heo, hea, hia and rarely hie, hi (pl. and f. sg.), hiu (f. sg.); ðio, ठiu etc. v. Pronouns $\S \S 181,182,183)$; 
fiondas XII. 36 ; friað Pref. 3, XXI, 4. XXVIII; treo XIV. 58, бrea IX. 5, бrio VIII. 2, oria (ter) XIV. 30, 72.

$i+a$ appears as io in the loan-word: dioblas I. 34, 39, IX. 38, Pref. 3. XXI, 4. XXVIII, diowbla I. 32, diowl III. 23 etc. (16), (v. $\S 93$ ). ia in diables (diaboli) Pref. 1.12 may be $i a$ for io, or possibly it has been confused with the Latin below (ef. medo (medios) VII. 31).

$i+e$ appears as $i e$ and $e$ (ee) in: sie (Subj. sg.) I. 17 etc. (24), se X. 43 etc. (5), sèe (1), see (1), sie (pl.) IV. 38 etc. (6), se (2), sèe (1), see (1), (v. § 138. 1, sie (esse) XII. 18 etc. (3), ef. S. $\S 427$, anm. 2$)$.

4) WGmc. $\hat{\imath}+a$ appears as $\hat{\imath}$ (v. S. $\S 166.4$ ) in wriga XIV. 65 (v. S. $\S 383$, anm. 2). For tuaes t getuiga (haesitanerit) XI. 23 , v. S. $\S 414$, anm. 4 .

5) For WS. $\hat{e} a$ before $h$ in hêah, nêah v. $\S 61$, heh, neh etc.

êa occurs in: heanise IV. 5, XI.10, XIII. 27; neawung XIII. 28 (v. $\S 82$. II, Note); $\hat{e} o$ in: geneoleces X. 7 etc. (11), (v. $\S 46$. 4, Paul, P. B. B. VI, p. 91).

6) Corresponding to WS. siehst, hiehsta, nîehsta with preservation of $h$ occur: gesiist, -siis V. 31, XII. 14; heista V. 7; nesta VI. 36 etc. (v. $\S 61.1$ ).

\section{B. The Vowels of Medial and Final Syllables.}

Chapter IV. Suffixes, Prefixes, and Compound Words.

For the origin of the variation or gradation of suffix vowels, of which the examples in St. Mark are given below, $\nabla$. S. $\S \S 127$ ff., Z. $\S \S 23$ ff., and L. Chapt. IV. $§ 25$.

The examples of weakening and of syncope of medial vowels in the Preterites of weak verbs will be given in Part II; as also the variations in the inflectional syllables of nouns etc.

565. Traces of original ablaut in the neut. suffix -os, -es.

The only examples are: dogor VIII. 2, XIV. 58, dogrum XIV. 1, beside doeg (die) Pref. 5.17 etc. (10), (v. S. \$§ 228, anm. 1, 289, and anm. 2); in eher (in spica) IV. 28 (v. S. § 289).

6 66. $-u d,-e d$. The examples are:

heafud VI. 24 etc. (9), heafod XV. 19 (heafda XV. 29); uutedlice VII. 28, uutet-VII. 6 , otherwise only the root syllable 
uut- is written out, and the rest denoted by a sign in the MS. $e$ also occurs in the loan-word cecced XV. 23, 36 .

-od in: gigote X. 20.

567. Abstracts in -nis, -nes.

The common form is -nis 95 , beside -nes only 8 . The examples of -nes are:

cyðnese Pref. 4. XXXI (beside -nise, 11); gelicnes XII. 16, onlicnese Pref. 5. XXXVIII (beside gelicnise XVI. 12); setnesa VII. 13, setnessa I. 14, selnesse VII. 3 (gesetnisse VII. 5); toslitnessa II. 21 (beside -slittnise XIII. 14); genitnesa XIV. 63 (beside witnise $\mathrm{X} .19)$.

(For -nis, -nise beside -niss, -nisse v. $§ 103$.

5 68. Substantives in -ung, -ing.

The commonest form is -ung 57 (sbs.), and without exception in adverbs 7 ; -ing 9 ; and the further variations -ong 3, -eng 3. Final $g$ is sometimes written $c$ and $c g$ (v. $\S 100.5$ ). Examples of 1) -ung are: somnung I. 27 etc. (v. $\S \S 146,147)$. The adverbs are: in eauung (palam) IV. 22, eanunge VI. 14 etc. (3); niwunga XIV. 40; woenunga XI. 13, XIV. 2 (v. § 176. 4).

2) -ing: aring I. 35, XIII. 35; -beging I. 40; ceping (com-; paratione) Pref.2.VII; mi $\succsim$-gearning ( $t$ foregearuung) Pref.5.XLIV utiorninsc (proflu[u]io) V. 25 (-insc $=$ inc v. § 100. 5); lesinc $\mathrm{X}$. 45; behleing (proditione) Pref. 5. XLIV (= WS. belôwwing v. $\S 82$. I (2); ge-moetingum XIII. 9; rowincg VI. 48.

Corresponding to WS. moestling, masling (aes) occurs the form: moeslen VI. 8, maslenn XII. 41.

3) -ong: efolsong VII. 22, Pref. 3. X (beside -ung III. 28, XIV. 64); setnong XV. 7.

3) -eng: eft-boeteng Pref. 2. VIII; ceigeng Pref. 2. III; groeteng Pref. 5. XL.

Note. hracengo (catenas) V. 4 is apparently an error for *hracentego, ef. hracentegum (catenis) preceding. Rushw. has racontege.

6 69. -und, -end. The only examples are: tusend, -o V. 10, VI. 44 etc. (8), (v. $\S 178$ ); and with loss of $d$, erenwreca Pref. 2. V.

The suffix -unt occurs in: бiofunto VII. 22 (v. Paul, P. B. B. VI. p. 237).

5 70. For the occurence of non-umlanted forms of the adj. monig beside that of the umlanted form menig from orig. -ag, -îg, v. § 2. 3, monig (29), beside menig (22), (cf. L. § 25. 3). 
Beside synnig III. 29 etc. (4), occurs -sunigo II. 15. 51. 1) Pret. Parts. in -on, -en.

The traces of orig.: -en are: ge-doen VI. 2 ; gehoen XV.15, 32, XVI. 6; unðuegenum VII. 2, Pref. 3. XX.

In geswoerenum VI. 26, the vowel may perhaps have been taken over from the Inf.; v. $\S 32.2$.

2) -on. Variation of the vowel (whether original or developed from a syllable-forming $n$ ) before a single final $n$ occurs in: becon VIII. 11, 12, XIII. 4, XIV. 44, Pref. 3. XXIV, beside beceno XIII. 22, becenum XVI. 20; tacon XV. 26, Pref. 3. XXIV, taco XIV. 44, beside taceno XIII. 8, tacenum XVI. 20.

$o$ beside $a$ occurs in seofona XII. 22, 23, seofana VIII. 20, the $n$ is lost in seofo VIII. 5, 6, 20, XII. 20, seofa VIII. 8 etc. (4).

$o$ in heofon XIII. 31, otherwise only syncopated forms occur; and always in recone V. 2 etc. (8), reconlice VI. 25 etc. (3). $i$ occurs in latin V. 41.

In other cases only en: facen X. 19; morgen XV. 1, XVI. 9 (on merne XV. 1); wolcen IX. 7; etc. etc.

3) Variation before $m$. Only $u$ occurs in the obseure form lustum (ultro) IV. 28, lustume VII. 12 (v. L. § 25. 7); wostm IV. 7,8 ete. (6), always without the vowel.

5 72. Variation before $l:$ 1) $a, o, u$ in: apostolas VI. 30; asales IX. 42 (asalde Pref. 4. XXXV, v. $\$ 96$ ); discipul Pref. 1. 2 ; riofol (lepra) I. 42; titul XV. 26.

For saul VIII. 35 (2), saules VIII. 36 v. S. $\S 6$, anm. 1. "sa(w)ul".

2) $e$ in: ceðela XVI. 1 (v. Paul, P. B. B. VI, p. 245); camel X. 25, camelles I. 6; engel I. 2, Pref. $2 . \mathrm{I}$ (otherwise always syncopated); geafel XII. 14; gegerelad V. 15, gegerelo II. 21, V.28, XI. 7; idelne XII. 3 (idilnesse VII. 7); lytel I. 19, lyttel X. 15, lyttelra VIII. 7, lytelo V. 3 (otherwise syncopated); micel XIV. 15, XVI. 4, miceles IX. 21, micelo IV. 41 etc. (3), michel IV. 5, michelo IV. 37, 39 (michil V. 11 otherwise syncopated); oe del VI. 1, 4, Pref. 3. XV; sauel VIII. 37, X. 45, XII. 30, XIV. 34, Pref. 4. XXVII, sawele III. 4, XII. 33; gesaweled Pref. 1.7 (saul, saules above); fot-scoemel XII. 36 (v. § 23. 2); symbel (cenam) VI. 21, XV. 6; yfel VI. 49, VII. 22, yfelo VII. 23. (For the syncopated forms of these words v. $\S 76$ etc.)

3) $i$ in: Atil-wald Pref. 1 (beside ceðela above); idilnisse VII. 7; бaccilla IV. 21 (v. S. § 129, anm.); Jyril X. 25. 
673. Variation before $r$ (of original or secondary vowel, cf. § 71. 2): 1) $a, o, u$ in: aldor I. 44 etc., aldordōm X. 42, aldormonnes V. 38 etc.; bolstâre IV. 38 (wrongly accented v. § 38. 5); morðor-slago VII. 21, XV. 7; ombor XIV. 13, ombora VII. 8 (v. Pog. § 275); snotorlice XII. 34; sundur (seorsum) VI. 32, sundurlice VII. 33, suundorlice XIII. 3, suunduria XIV. 66; undorlic XII. 11.

(For the names of relationship in $-r$ v. Declensions $\$ 163$ ).

2) $e$ in: cefterra IV. 19, XII. 21; efter II. 13 etc.; fingeras VII. 33; hider XI. 3; hueðer III. 2 etc.; hwider VI. 10 etc.; hyngerde II. 25, gewyncerde XI. 12 (error for gehyncerde); iuer II. 16 etc., iuera VII. 13, iuerra XI. 25, iueres X. 5, iuero XI. 26; ofer VI. 45 etc.; oðer II. 21 etc., oðerne XII. 4 etc., oðero VI. 15 etc.; sumer XIII. 28; timber XIII. 1; under XII. 40 etc.; user IX. 22 etc. etc. (For caseri XII. 14 etc. v. Masc. sbs. in -ere § 77. II.)

\section{Prefixes.}

673. I. gi-, ge. The regular form is ge-. The only instance of $g i$ - is gisceh XII. 34 ; gie- in IV. 13 is apparently a scribal error due to confusion with the Pron. gie-, the gloss is: gie ge-cunnas $t$ gie-cunna gie magon (cognoscetis).

go- occurs in: gofoerde VIII. 27, where it is probably merely a scribal error.

The $e$ is syncopated in: gleafo (fidem) XI. 22 (beside geleafo 3); se groefa (pilatus) XV. 5 (beside geroefa 2).

II. $b i-, b e-$. The lengthened form $b \hat{\imath}$ occurs in the Prep. bi X. 11, XII. 35; bismeragad XV. 20 etc. (4), bispell IV. 10 etc. (13), (v. § 52. 3).

Exclusive of these instances, bi- occurs 22 times, be- 44.

$b i$ - with verbs of motion is separated by a byphen, and retains the sense of the preposition as a gloss to the Latin proeter-, trans-. Only in the case of bi-hianda, and bituih do both forms of the prefix occur in the same word.

The examples are 1) bi-: bi-cerre (Inf.) VI. 48; bi-eodon IX. 30; bi-farende XV. 21, 29; bi-geongende XV. 21; lond-bigencgum XII. 1; bigienda X. 1; bi-hianda V. 27 (beside behianda VIII. 33); bi-leorade XIV. 35, 36; bituih XVI. 3 etc. (12) (beside betuih XII. 7). 
2) be in: bebead III. 12 etc. (12); bebod VII. 9 etc. (3); bebycendo XI. 15 etc. (3); becymed XI. 24, XIV. 31; begeatta XIV. 5 ; beheald XII. 41 etc. (11); beleede (proderet) XIV. 10; bewand XV. 46 ; befora XIV. 28 etc. (8); behianda VIII. 33 (beside bihianda above); betuih XII. 7 (beside bituih 12, above).

The vowel is regularly lost in the contracted form buta V. 37 etc. (19).

III. fore- and for- are as a rule not interchanged. They are very rarely written out as in: forewoearp $\mathrm{X} .50$, for-letas X. 11; the -or being generally denoted by a sign in the MS. (cf. L. $§ 26$. I. p. 50).

Examples of fore- beside for-without any difference in meaning are: f-e-beadend (prohibens) Pref. 4. XXXII, beside f-beodend (prohibens) Pref. 4. XXXI etc.; f-styldton (obstupuerunt) V. 42, XVI. 5, beside t-styldton (obstupescebant) X.24.

IV. af-, of-. af- only occars in afist (inuidiam) XV. 10 (v. S. § 43, anm. 4), otherwise always of- (cf. L. $§ 26.1$ ).

V. at-, ot. The common form is at (aed-aed), ot does not occur.

For $a t$ - beside $a d-v . \S 95$.

VI. Beside the usual form eft- occurs once efet-: efetawaelted (reuolutum) XVI. 4.

VII. $\hat{e}(=$ WS. $\hat{a})$ occurs in: erest (sb.) XII. 18 etc. (6); espryngc V. 29; escuicnis VII. 21 (v. § 44.2). 200).

VIII. ond-, on-, un- (v. Paul, P. B. B., Vol. VI, pp. 199,

Examples are: 1) ond-: ondget (sb.) XII. 33; ondspurnad IX. 45 etc., geondspurnad IV. 17 etc.; onduearde X. 3 etc., geonduearde XII. 17 etc.; ondsworade XIII. 2, geondsuarede XV.5 etc. (3), (v. on-).

2) on-: ondreard V. 33 etc. (v. Paul, p. 199); onfoe X. 17 etc., on-feng VII. 34 etc.; ongcet VIII. 17 etc., on-geton VI. 33 etc.; on-sacca (Inf.) Pref. 1.15 etc.

The only word in which ond- and on-interchange is onswarega XIV. 40, onsuarade III. 33, XIV. 40, 48, ge-onsuarede XIV. 61, beside ond- (3), (v. 1) above). For ôn (Prep.) Pref. 3. $\mathrm{X}$, v. $\S 38.4$.

Beside on dune XIII. 3, occurs adune II. 4 etc. (4).

3) un- in: un-binde XI. 4 etc.; undoa I. 7; untyn VII. 34 etc. (3); unðehton II. 4 (v. Paul, p. 200) etc. 
IX. For derh v. $\S 10.4$.

X. For in- beside inn- v. $\$ 103$.

Second Members of Compounds.

675 . For the modifications and changes of root vowels in nnstressed or slightly stressed syllables v. S. § 53, and anm. Examples in St. Mark are: ea-a geonduarde XII. 28, XV. 12 (v. § 11. 1).

ea-o doruorde XIII. 34; niotuord XV. 38 (beside inn-, to-, ufa-veard (5); wiðer-word III. 23, VI. 48, wiðerworda IV. 15, VIII. 33 (beside -wearda 3) v. § 11.3 (cf. S. § 43, anm. 3).

$a-e$ dom-êrn XV. 16 (v. § 38.4).

Further changes have taken place in: hlaferd XII. 9, XIII. 35, hlafurd II. 28 (for *hlaf-weard); ebolsas II. 7 etc. (8), efolsong VII. 22 v. $\$ 9.5$ (from *ef-hallsian v.S. § 43, anm. 4); orig. $\hat{\imath}$ has disappeared in the common words: ilca I. 31 etc. (30), (v. § 186); huelc VIII. 4 etc., hucelc VI. 2 etc., swelc X. 15, swoelce IX. 26 etc., v. $\$ 23.1$; hulco XIII. 1 (beside hulic V.16, huulig XIII. 1); for tullucum IV. 33, tullico VI. 2, v. S. § 349; woruldes IV. 19, Pref. 4. XXXII, world X. 30 (v. § 35. 2); afist (inuidiam) XV. 10 (from af-êst); larua (rabbi) IX. 5, 38 etc. (5), laruua IX. 17, laruu II. 16 etc. (11), ae-laruuas X. 2, alaruas VIII. 15 etc. (4), (v. § 142 . I etc.) (from *lâr-ðêew); for oht XV. 24, noht VII. 15 etc. (5), aniht XIV. 60 etc. (5), v. S. $§ 348.1$, 2; for uðuta I. 22, II. 16 (from *aঠ-witan), beside uиठwuta XII. 32 etc. (19), v. § 37.1.

But in the majority of compound words the second member remains unaffected by its position, e. g.: lichoma XIV. 38 etc. (14), losiust VIII. 36 etc. (3); fuluiht 1.4 etc. (9), fulwuiht Pref. 4. XXXVII, fullwihtere VI. 14, VIII. 28, and VI. 24, 25 (v. $\S 142$. II. (2).

Chapter V. Syncope of Middle Vowels.

For the rules concerning the treatment of middle vowels (original, and developed before syllabic $l, r, m, n)$ v.S. $\S \S 143$, and $\mathrm{ff}$.

6 76. Single Middle Vowels. "Every middle vowel of a trisyllabic word, when originally short, and not rendered long by position, is syncopated after a long radical syllable". S. $\S 144$ a. 
"After a long radical syllable an auxiliary vowel (v. § 138) is lost when a termination is added", v. § 148.

The examples in St. Mark are:

I. Before $l$ : adle V. 29, 34, aðlo III. 10, adlum I. 34; cyrtlum VI. 9; degle IV. 22, deglice IX. 28, gedegled IV. 22; dioblas I. 34, dioble Pref. 3. XXI, 4. XXVIII, diobles I. 39, Pref. 1. 12, dioblum IX. 38, diowbla I. 32, diowla III. 15 etc. (10), v. § 64.3 (without the addition of a termination, diowl III. 23 etc. (6); engla Pref. 1. 13, englas XII. 25 etc. (4), engles Pref. 1. 5, englum VIII. 38 (uninflected engel I. 2, Pref. 2. I, v. § 72. 1); lylla Pref. 5. XLI, lytle XIV. 70, lytlo X. 14, lytlum Pref. 1.13 (uninflected lytel I. 19, lyttel X.15).

nedles X. 25; saules VIII. 36 (uninflected saul VIII. 35 (2) v. $\S 72.1$, S. $\S 6$, anm. 1); temple XIII. 1,3 etc. (6), temples XV. 38, Pref. 5. XLII (uninflected, tempel XI. 15, 16 etc. (6).

Exceptions are: sawele (acc. and dat. sg.) III. 4, XII. 33, gesaveled (animatum) Pref. 1. 7 ; lytelo V. 3 (beside lytlo X. 14) v. S. $\S 396$, anm. 2.

II. Before $r$ (for relationship nouns v. Declensions $\$ 163$ ): nøfra II.12, XIV.29; ceastra I. 45, VIII. 27, ceastre XI. 19 etc., ceastrum VI. 33,56 ; culfras XI. 15, culfre I. 10; dogrum XIV. 1 (uninflected, dogor VIII. 2, XIV. 58); eastres Pref. 5. XLIV, eastro XIV. 1 etc., eostro XIV. 12; februm I. 31; feowrum II. 3 (uninflected, feower VIII. 9 etc.); hungro XIII. 8; iurum VI. 11, hiurum II. 8 (uninflected, iuer II. 16 etc.); otrum X. 12 etc. (4) (uninflected oter II. 21 etc.); snytru VI. 2 (snotorlice XII. 34): sundrig VI. 31, syndrige IV. 34, syndrigo Pref. 2. 2, syndrigon IV. 10, suindrige IX. 2, siundrio Pref. 1. 13, snyndria XIV. 19; getimbradon XII. 10, getimbras XV. 29, ic getimbro XIV. 58, getimbro (sb.) Pref. 5. XLII (uninflected, timber XIII. 1); Jiostrig VIII. 17, Jiostro XV. 33, ge-ðiostrod XIII. 24, fore-geठistrat VI. 52; usra IX. 22 (uninflected, user IX. 22 etc.); wintra V. 42, wintro XIII. 18, wintrum V. 25; wuldre VIII. 38 etc.; wundra Pref. 5. XLV, wundrum VII. 8, gewundrade XV. 44; winstra X. 40, wynstra X. 37, wynstrum XV. 27.

Comparative forms: aldrum (parentes) XIII. 12, celdra VII. 5 etc.; lengra XII. 40; strongre I. 7; swiðra (sb.) X. 40, suiðre X. 37, swiठrum XVI. 5 etc. (suiðor (adv.) VII. 36 ete.); etc. etc.

$-r$ inflections of Adjs.: allra IX. 35 etc.; un-claenra VI. 7 etc., synnfullra XIV. 41 ; etc. ete. 
Exceptions are: feowero Pref. 1 (beside feowrum), fingeras VII. 33; hyngerde II. 25, gewyncerde (esuriit) XI. 12 (beside hungro, v. S. § 405. 5); ombora VII. 8 (uninflected, ombor XIV. 13); sunduria XIV. 66 (uninflected, sundur VI. 32, unless the line over the $r$ indicates some termination; beside syndrig etc. 7); getimberde XII. 1 (beside getimbradon etc. 4, v. S. § 405. 5); cefterra IV. 19, XII. 21.

For iuera VII. 13, iuerra XI. 25, iueres X. 5, iuero XI.26; and otero IV. $18,19,36$ etc. v. S. § 144 b.

A svarabhakti vowel has been developed between $r$ and $h$ in wyrihte VI. 3 (wrihles Pref. 3. XV), bat v. C. N. 142 "wrihle with $y$ above between the $w$ and the $r$ " which would point to the $i$ having been written as the root vowel.

III. Before $m$ : the only examples are vcestmia IV. 20, 28 (uninflected, wastm IV. 7 etc. (6); and utmestum V. 23.

Before n: a) inflected Past Parts. in -en: gehalne (acc. sg. m.) Pref. 1. 15; forletnum I. 18; unforletne XII. 20; awordne IX. 3, XV. 33.

Exceptions are: gebundenum XV. 6; forlelenes Pref. 1. 12.

b) other words: becnum Pref. 5. XLVI (uninflected, becon 5); drihtne XVI. 20 etc. (7), drihtnes I. 3 etc. (5) (uninflected, drihten 9, drihtenlica); facne XIV. 1 (uninflected, facen X. 19); haedno Pref. 4. XXXIII, haednum XIII. 10 etc. (3), (uninflected, hœeðen VII. 26); lecnade I. 34, leicnung Pref. 2. VI; møgdne V. 41 etc. (3), maedne V. 40 (uninflected, magden V. 41 etc. (4), maeden Pref. 3. XIV etc. (3); merne XV.1 (beside morgen XV.1 etc); wodnes doege Pref. 5. 16; wolcne IX. 7, wolcnum XIII. 26, XIV. 62 (uninflected, wolcen IX. 7), (woepen X. 6, only the uninflected form).

Exceptions are : beceno XIII. 22, becenum XVI. 20, (beside becnum); bisene Pref. 4. XXXIII, biseno IV. 34, VII. 13 (uninflected, bissen VII. 17); taceno XIII. 8, tacenum XVI. 20 (uninflected, tacon XV. 26, Pref. 3. XXIV, taco XIV. 24).

IV. 1) Before $d$ and $\delta$ : heafda XV. 29 (uninflected, heafod

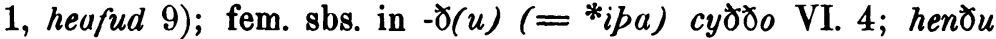
XII. 44; megða VIII. 10; merठu I. 28.

An exception is: unreht-haemedo VII. 21. (For the Pret. endings of weak verbs v. $\S 132$. II.)

2) Before g: genitga (prophetisa) XIV. 65. 
V. Before $s$ : gebloedsad XI. 9, 10 etc. (v. § 50. 1); clensanne Pref. 1. 15, gecleensiga I. 40, 41 ete. (v. §42.1); ic halsigo V. 7; mersiga I. 45 etc. (v. § 45); millsa X. 48, milsa X. 47 etc. (v. § 7. 2); unrotsia XIV. 19 etc. (v. § 47. 2).

No te. $u$, where WS. has $e$, before $s$ occurs in cuic almus (nictima) IX. 49 (v. § 1. 5) v. Sw. H. E. S. p. 284: ${ }_{n}$ almus (North.) from 0J olmusa ${ }^{4}$.

VI. Before $g$ : witge VI. 4, Pret. $3 . \mathrm{XV}$, witgo I. 2, VI. 15, XI. 32, XIII. 22, witgom VI. 15, witgum VIII. 28, gewitga (prophetisa) XIV. 65. Adjs. only: halgum VIII. 38; noengum Pref. 3. $\mathrm{XXV}$, otherwise without syncopation.

Non-syncopated are: cenige VI. 5, cenigum XVI. 8 etc. (4), nanigum I. 44, VIII. 26 (beside nongum Pref. 3. XXV); haligum XIV. 2; meehtiga IX. 23; bersynnigum II. 16 (beersunigo II. 15); un-trymigo VI. 5, 13, 56, untrymigum XVI. 18; woestigum I. 35, 45. (For syndrige v. III.) $\S 145$.

5 77. Vowels long by position are not syncopated, v. S.

\section{Examples are:}

I. Subs. in -en, -enne: byrgenne VI. 29, XVI. 2, byrgennes XV. 46, XVI. 3, byrgennum V. 2, 3, 5 .

II. Subs. in -ere (-are): boecere Pref. 5. XL; casere XII.17, caseri XII. 14, caeseres XII. 17, Pref. 5. XXXVIII; tiscera Pref. 2, III, fisceras I. 16, 17; legerum (hypocritis) VII. 6; godspellere Pref. 1. 1; sceware VI. 27; sedere IV. 3, 26; setnerum XV. 7 fullwihtere VI. 14, VIII. 28.

$e$ is syncopated in mynetro XI. 15 (v. § 78. V).

III. Superlative forms: aldesto XI. 27; lesestum IX. 42; leofusle IX. 7; yrrestum Pref. 4. XXXVII.

$e$ remains in the subs. oefeste (festinatione) VI. 25.

Syncopated are: heista V. 7; nesta VI. 36 etc., neesto XII. 33 etc. (v. S. § 145).

IV. Present Participles: oehtendum X. 30; scinendo IX. 3; wundrande I. 27; etc. ete.

5 78. After a short radical syllable the middle vowel remains, and an auxiliary vowel occurs more frequently (v. S. $\S \S 144$ a, 148, P. B. B. V, pp. 75 ff.). Exceptions are the inflected forms of micel and yfel (v. S. \& $144 \mathrm{c}$ ).

The examples here show even more irregularity than in the case of the long radical syllables. 
I. Before l: ceðela XVI. 1; asales IX. 42, (asalde Pref. 4. XXXV. v. § 96); camelles I. 6 (uninflected camel X. 25); gegerelad I. 6, V. 15, gegerelo II. 21 etc. (3); miceles IX. 21, micelo IV. 41 etc. (3), michelo IV. 37, 39; dacccilla IV. 21; yfelo VII. 23.

Exceptions are: eorठcryple II. 9, Pref. 2. VI, eorठ-crypple II. 5, 10 (uninflected eorðcrypel II. 3, eorðcryppel II. 4); micla XV. 37 etc. (5), micle I. 26 , XV. 34 , miclo V. 7 etc. (7), miclum XV. 4 (beside miceles etc. above; uninflected micel IXIV. 15, XVI. 4, michel IV. 5, michil V. 11); yfle I. 32 etc. (7), yfles XV. 14 (beside yfelo above; uninflected yfel VI. 49, VII. 22).

No auxiliary vowel occurs in: fuglas IV. 32 ; hragle XV. 17, hraglo XIV. 63 (uninflected, -hragl XV. 38); setla XII. 39, sedlo Pref. 4. XXXIII, seatlas XI. 15, seallum XII. 39; symle XIV. 7 etc. (4).

II. Before $r$ : ehera Pref. 2. VIII; teherum IX. 24; but the vowel is syncopated in: feotrum V. 4 ; fattro V. 4 (v. § 13.3); cedgeadre VI. 22 etc. (4), gegeadrad X. 9; niठrað Pref. 3. XX, niठria IV. 1, 37, 38, niðriendo Pref. 4. XXXII, geniठrad IX. 12, XVI. 16, geniðradon XIV. 64; betra IX. 42, 43; ठisra XII. 31 (S. § 338, anm. 2).

An auxiliary vowel appears only in: derne legero VI. 21; otherwise: hueðre V. 40, huoeðre X. 43 etc. (3) (beside hueðer III. 2 etc. (3), huoeðer VIII. 23, XV. 44, v. Z. § 25. B. b, P. B. B. V, p. 76); Junres III. 17; waetre I. 8, 10, watres IX. 41, XIV. 13, waetro IX. 22.

III. Before $m$ : the only example is: loetmest XVI. 14 etc. always with syncope of the middle vowel.

IV: Before n: gecoreno XIII. 22, 27, gecorenum XIII. 20; fordrifenum V. 40, lodrifeno XIV. 27; geswoerenum VI. 26; unбuegenum VII. 2 (un-ठuegnum Pref. 3. XX); recone V. 2 etc.

The vowel is syncopated in: cwoedne (m. acc. sg.) XIV. 58, cuoednum XIV. 26, gecuoedna Pref. 2. 3; forgetne VIII. 14 (v. C. N. 143 "forgetone alt. to forgetne"); on-setnum VI. 5, VIII. 23; un-ठuegnum Pref. 3. XX; heofnas I. 10, heofne VI. 41 etc., (6), heofnes XIV. 62 etc. (4), heofnum VII. 34 etc. (7) (uninflected heofon XIII. 31); ge-opnadon II. 4.

No auxiliary vowel occurs in : efne II. 2, III. 20 etc., efnum Pref. 1. 9; gedrysned (extinguitur) IX. 44, 46, adrysnede Pref. 3. XIII, adrysnendlic IX 45 (v. § 90.3); esne X. 44 etc. (5); gefraigne (Inf.) XII. 34, gefraignas IX. 16, gefroegnade XV. 2 ete. 
etc. (getragn IX. 21 etc.); togagnas IV. 35, V. 2, XVI. 17 (ongagn XII. 41 etc.) v. Z. § 25. B. d; maegna XIII. 25, maegne IX. 1, XII. 30 , XIII. 26 , v. Z. § 25 B. d; nemned VII. 26, XII. 41, Pref. 2. I; somnung I. 21 etc., gesomnad I. 33, IV. 1 etc. etc.; stefne I. 20, V. 7 etc., stefnes Pref. 1. 9, (uninflected stefn I. 3 etc. (4); Jegnas II. 18, 23 etc., 万egne Pref. 4. XXXV, бegnna Pref. 5. XLVI, Jegnum II. 15 etc.

V. 1) Before $\succsim$ : gigoðe X. 20; nigoða Pref. 5. XL.

The vowel is syncopated in: gefremठiga XIV. 71 ; sih ${ }_{0}$ IX. 9 (v. P. B. B. V, p. 78).

2) Before $t$ : mynetro XI. 15 (v. P. B. B. V, p. 78).

3) Before $d$ : genacedon II. 4. For the Pret. forms of wk. verbs v. $\S 132$. II etc.

VI. 1) Before $g$ : hefigo (adj.) XIV. 6.40; monige IX. 26, monigo I. 34 etc., monigum V. 26 etc., menigo (sb.) II. 4 etc.; wealigo XII. 41.

2) Before $c$ : tunucum VI. 9.

6 79. Two Middle Vowels.

The second of two middle vowels is always syncopated (v. S. § 14).

The regular examples are: lyttelra VIII. 7; baer-synnigra Pref. 2. VII; anigne V. 37; haligne III, 29; ahongene (acc. sg. m.) XVI. 6; idelne XII. 3; oðerne XV. 27 etc.; Jyrnenne XV. 17.

Both middle vowels are syncopated in: cuoedne (acc. sg. m.) XIV. 58, gehutne Pref. 1.15 ; stcenne XIV. 3 may possible belong here, but v. $\S 90.3$.

\section{The Consonants. \\ Chapter VI. Semi-vowels.}

$n$.

680. The semi-vowel $w$ is most frequently written $n$, but the sign $u$ is very common, and instances occur of $w u, u u=$ $w$. In Mk. I. occur $82 w$, beside $32 u$.

1) The examples of $w u=w$ are: wurce V. 7; ge-wuritto XII. 24; wuorठ (atrium) XV. 16; wuosa X. 26; fulwuiht Pref. 4. XXXVII; widwuana XII. 40; gefulwuad VII. 4, X. 38, 39, in-gefulwuade X. 38 .

2) $u u=w:$ gegiuudon XV. 6 (v. § 136. 7); gesuuinged XIII. 9; suuippum (flagellio) XV. 15; ae-laruuas X. 2, laruua IX. 17. 
$u w=w$ in giuvende Pref. 4. XXXIII (v. § 51. 2, Note).

$v=w$ does not occur. The sign $v$ is only once written and there for the vowel $u$, marcvs Pref. 1.

According to Bonterwek (p. CXXXV) an inorganic $w$ before an initial $u$ appears in: Jerh wurnon (percurrentes) VI. 55, geuurnon IX. 15, efne-ge-uurnon VI. 33; wusig XI. 9; wuঠuuto III. 22 etc. (8), (beside uuð- (6), uð VII. 5 etc. (7). Probably however this $w u$ is only a way of writing the vowel $u u=a$ v. $\S \S 10.3,38.2$, ef. $w=\breve{u}$ in swyndria XIV. $19=$ suindria (v. $\S 27.4)$.

\section{Initial $w$.}

6 81. Initial $w$ occurs: 1 ) before all vowels (for its influence on a following vowel, v. \$§ 32-37). Examples are: wacan VI. 48; wer VI. 20; wind IV. 41; worठ XIV. 68; gewuna XV. 6; wôedo X. 50; win II. 22; wodnes doege Pref. 5.16 etc. etc.

$w$ is lost: a) in certain verbal contractions with the particle ne (v. S. $§ 172$, anm.) e. g.: nalde I. 34, noelle XIII. 11; noes II. 27, nere II. 26 etc. The negative forms of wuta (scire) are: nât XIV. 71; neutu woe XI. 33, nuutogie XIII. 35; beside ne uutogie X. 38, XII. 24, ne wuto gie XIII. 33.

b) in the following compound words: hlafurd II. 28 etc.; ceniht XIV. 60 etc. (3); oht XV. 24; noht VII. 15 etc. (5), (v. S. $\S 348.1 .2$ ); uðuta I. 22, II. 16 (beside -uuto VII. 5 etc. (19), v. $§ 75)$.

2) $w$ is preserved in the combinations $w l$ and $w r$ : megwlitlice Pref. 4. XXX; wlonco XII. 41; wroht XIII. 14; writto XIV. 49 etc. etc.

3) $w$ occurs as the second element in the consonant combinations $c w, d w, h w, \delta w, t w, s w$. Examples are: cuic IX. 49, XII. 33; gecuoellas XIII. 12 etc.; duolas XII. 24, 27; hwate IV. 28; huitum Pref. 5.17 etc.; un-ठuegnum Pref. 3. XX; 万uongas I. 7 etc.; tuoelfo VIII. 19 etc.; tuaes (haesitanerit) XI. 23; betuih XII. 7 etc.; gesuoercde I. 34 ; suiga I. 25 ; suord XIV. 47 etc. etc. $w$ is lost in: coeða X. 19, coeðanne II. 9 , coeðe I. 44, coed (ait) XIV. 22, coeð XII. 26, 35; coern (mola) IX. 42; hu XV. 4 etc., hulic V. 16, hulco XIII. 1, huulig XIII. 1 (= halig); tuu XV. 38 (v. S. § 172, anm.).

Note. suaha XI. 23 is a scribal error for sua hua IX. 42 etc. (v. § 186). 
Medial and Final $w$.

82. I. $w$ after Vowels.

The examples are:

1) after 2 : sawel Pref. 4. XXVII etc. (3), sauel (2), sawele III. 4, XII. 33, ge-saweled Pref. 1. 7, (saul VIII. 35 (2), saules VIII. 36, v. § 72, S. § 174. 3); snaua (nix) IX. 3 (v. S. § 250. 1); -cnawanne Pref. 1. 13, -cnauanne Pref. 1.8 etc. (v. § 40); sauaठ IV. 16,18 etc. (v. $\S 40$ ), ef. L. $\S 28.2$ a.

2) after $\hat{e}$ (= Gmc. $\hat{a}) w$ is lost in: beleede (proderet) XIV. 10 (v. S. § 174. 3), and behleing (proditione) Pref. 5. XIV (with inorganic $h$ v. $\S 101.1)$.

3) after $\hat{o}$ : stowe XV. 22, stouo I. 35, stowm I. 45, -stow VII. 4 (v. § 47. 2); trowende Pref. 4. XXVI, XXVII, trouenda V. 26, trowungo V. 26, Pref. 5. XLV (beside troung Pref. 5. 17, Jrounc VIII. 34), -trower I. 40, Pref. 2. VI; rowincg VI. 48.

4) after êa: aed-eaw I. 44 etc. (จ. § 56. 2), eauung IV. 22 eanunge VI. 14 (beside eaunga VIII. 32. For enunga I. 45 v. $\S 62)$; sceawung XII. 40, -sceavade V. 32, -sceawde III. 5 etc. (v. § 56.2), (for scevure, -sceuade v. § 62); gleoulice VIII. 25, ( $\hat{e} o$ for êa v. § 56. 3), -gleownise III. 5; geheawen (Past Part.) XV. 46. (For ceaulas v. $\S 40$.)

5) after $\hat{\imath} o, \hat{e} o$ (v. § 62): feower VIII. 9 etc. (4), (feuer VIII. 20, and with loss of $w$ : feor Pref. 3. XXIII, feortig I. 13, feoertig I. 13, feorठa VI. 48, Pref. 3. XIX, feorठung XII. 42); oncneow II. 8, oncneawn, oncneaun VI. 38, 52; gesean IV. 4 (êa for êo v. § 59. 2); hreowigas I. 15, hreownisses I. 4, VI. 12; iowh III. 28 etc. (4), iuh VI. 11 etc. (v. $\$ 62)$.

Beside dioblas I. 34 ete. (6), (v. §64. 3), occur forms with $w$ : dionl, diowla II. 22,23 etc. (16), diowbla I. 32 (v. § 93).

For $\hat{e} w=\hat{e} o w$ in: gebleuu VII. 33; oncnewa Pref. 2. 4, v. $\S 62$.

6) Examples of the development of original $e w, i w$ (v. $\S$ 62) are: cnewa XV. 19, cneuo X. 17, cnew-beging I. 40 (v. S. $\S 174.1)$.

The forms corresponding to WS. cnêoris (v. S. § 258, anm. 4) are: cneoreso VIII. 12 etc. (3), cnewreso IX. 19, cneoureso VIII. 12.

From the stem trewo- are: treuo VIII. 24, trewum XI. 8, XIV. 43, ðcem tree XII. 26 (v. S. § 250. 2). 
From the stem Jewo- are: Jio Jiwa (ancilla) XIV. 69, yiowum XIV. 66 (ঠea Pref 5. XLIII, v. § 58.3).

For larua IX. 5, 38 etc. from *lar-ðêow v. § 75.

Original iw: oferhiued IX.2, of erhiwade (pp.) Pref. 4. XXVII; niua I. 27, niwe II. 21, 22 etc. (3), niwes II. 21, XIV. 24, niuum XVI. 17, niwum II. 22, niwunga XIV. 40, eft-niuad VIII. 25; siuieð II. 21 (v. § 62).

For giuað (petitis) XI. 24 etc. v. 51. 2, note.

II. After Consonants: fulwade I. 8, gefulwad I. 5, 9 etc. (11), (v. § 10.2); gearwas I. 3, XIV. 15, foregearuas I. 2, gegearuad VI. 9 etc. (14), (v. § 11.2), mi -gearwing $t$ fore-gearuung Pref. 5. XLIV; widwa Pref. 5. XL, widua XII. 42, 43, widwuana XII. 40.

$w$ is lost in: gegerelo II. 21 ete. (3), gegerelad I. 6, V. 15; smirinis Pref. 5. XLIV etc., smiriane XIV.8, smiredon VI. 13 (v. $\S 14.2$, L. $\$ 28$ b).

Note. The $w$ in neavung (proximo) XIII. 28 is abnormal. B-T. gives no other instance of the occurrence of this form, neah-wist being the common word used to signify 'nearness, neighbourhood'. Possibly neavung is derived from an original *nehwjan with the accent on the final syllable, so that, in accordance with Sievers' low respecting the Gmc. consonant group $z w$, the $z$ was lost, and the $w$ remained.

gearuu XIV. 38 appears to stand for gearuw with the $w$ of the oblique cases affixed to the vocalised $w$ of the nominative (v. S. $\S 300$, anm.).

WS. lârêow (v. § 75) is written laruu V. 25 etc. (11), larua IX. 5 etc. (5), laruua IX. 17, pl. celaruas IX. 11 etc. (3), and alaruıcas X. 2, where $u u=w$ (v. $\S 80.2$, ef. S. $\S 250$, anm. 3).

$$
\text { j. }
$$

8 83. I. Initial $j$ (v. S. $\S 175$, Sw. H. E. S. $\$ \S 541-543$. L. $\S 13.1)$ is expressed by $i$ only in the proper names iacobes XV. 40 ; iordane X. 1, Iordanenes I. 5; Iarus V. 22 ; iosep XV. 45; iudas XIV. 43; iudea XV. 26 etc., otherwise it is denoted by $g$.

Examples are: gie (Pron.) II. 8 etc.; gif (si) III. 1 etc.; ging XIV. 51, XVI. 5 etc. (v. $\S 28)$.

II. Medial $j$ (v. S. \& 176) between vowels is preserved in the verb ceiga X. 49 ete. (v. $\S 63.1$ ); and in gefrigade X. 16, beside friað Pref. 3. XXI, friende IX. 36, gefriað Pref. 4. XXVIII 
(= gefriad Past Part. v. $\S 136.4$ ). It does not appear in any of the forms of smea, sineas VIII. 17, smead II. 8 etc. (v. $\S 136.4$ ).

After a short vowel $+r($ v. S. $\S 176) j$ is represented by $i$ in: gesuoeria XIV, 71, and by $g$, ig in: gebirged (gustabunt) IX. 1, gebiriydon Pref. 4. XXVII.

For the $i$ or $i g$ of the weak verbs of Class II: unrotsia XIV. 19 ; wunia IV. 32 , losiga III. 4, bodiga III. 14 ; ete. v. S. § 175 , anm.

III. Final $j$ occurs only in oferferig (transfer) XIV. 36, an irregular Imp. form. But probably the $-i g$ is simply due to contusion with the $2^{\text {nd }} \mathrm{sg}$. Imp. of weak verbs of Class II. in -ig (v. § 111. 3, ef. S. § 414, anm. 2).

Chapter VII. Liquids and Nasals.

\section{$r$.}

8 84. $r$ occurs very frequently in all positions. Examples are: rip-isern IV. 29; mor IX. 9; duru II. 2; brydguma II. 19; hrof XIII. 27; strongre I. 7; trittig IV. 20; screadunga VI. 43; eardes XIII. 27; eorठo XIII. 31; woerces XIII. 34; hearto II. 8; byrgenne XVI. 2; ned-ðarf II. 17; etc.

Geminated: fearre V. 6; steorras XIII. 25; etc. and in the loan-words carre (petra) XV. 46; torr (turrem) XII. 1.

85. Examples of metathesis of $r$ :

1) where $r$ originally preceded a vowel followed by $n n$, or s-combinations (v. S. § 179) are: arn V. 2 etc. (5); forbernde IV. 6 ; darsto VIII. 15 etc. (4); first (spatium) VI. 31 ; iornende IX. 25, blod-iorne Pref. 3. XIV, -iornað XIV. 13, -iornende IV. 5, utiorninsc V. 25; geðearsca XIV. 65 etc. (5).

2) where $r$ originally followed the vowel, the converse of the above metathesis. This occurs before $h t$ and is more especially characteristic of the North. dialect. The examples are: breht Pref. 3. XI, 5. XLII (behrto uaria Pref. 2. V); frohto IV. 40, frohtende Pref. 2. IV, gefrohtiga XVI. 6 (beside forhtiga XIV. 33, forhtade V. 33 (v. C.N. 142 "altered from frohtade"), fyrhto IV. 41 ete. (3), gefyrhtad IX. 6, in IV. 40 the two forms occur actually side by side frohto $t$ forhto (timidi); wrihtes Pref. 3. XV (beside wyrihte VI. 3 v. $\$ 76$. II, and worhte (vb.) X. 6 etc. (7).

3) Other cases of metathesis which do not directly come under 1) are: dom-êrn XV. 16; forma (primo) XIV. 12, XVI.9; 
gers IV. 28, VI. 39 (beside grasum IV. 32); tintergo IX. 47 etc. (3); Jirda IX. 31 etc. (5).

88. Examples of $r$ corresponding to Gmc. $z$ are: gecoreno XIII. 22 etc. (3), gecure XIII. 20, due to the working of Verner's Law; earo IV. 9 etc. (7); hered Pref. 2. IV; etc. Examples of original $r z$ are: merrunga (seductiones) Pref. 5. XLII; yrrestum Pref. 4. XXXVII; of original $z d$ : mearde (mercedem) IX. 41.

For $r$ in efern (uespere) I. 32, IV. 35, efrn VI. 47 etc. (6); faslern V.16 etc. (4); woestern I. 12 etc. (5), v. L. $\$ 56$. II, p. 105, H. § 3, p. 39.

In stcenes (petrosa) IV. 5 final $s$ is written for $r$. cf. Rushw. stanere IV. 5, 16, Lind. stonero IV. 16, and stoener (petrosa) Lind. Mt. V. 5, 28.

Possibly $s$ is written for $r$ in ymb-woeson Pref. 1. heading, woeson for -woeron? (Pret. pl.): Jas feowero mið gode ymb-woeson Jas bôc $=$ 'were occupied with, busied themselves with this book'? ymb an jing wesan = to be occupied with a thing.

For the loss of $r$ in ende brednise (ordinem) Pref. 1.4, beside WS. anbryrdnis v. S. § 180, Z. § 30 and anm. p. 76.

\section{$l$.}

87. $l$ in all positions is of very common occurrence. Examples are: leaf I. 11; woel XII. 28; weala IV. 19; scyld III. 29; salt IX. 50; wilnig VI. 22; bolstâre IV. 38; folc IX. 15; blind X. $46 ;$ geflugon V. $14 ;$ gladnise IV. 16 ; etc. Geminated: gefaello (ruituras) Pref. 5. XLII; godspell III. 14 etc.; willo XIV. 36; etc. For $l l$ beside $l$ in selle $\circlearrowright$ XIII. 12 etc., sele XIV. 18 etc., v. $\S 103$.

ll in tullucum IV. 33; Jullico VI. 2 is the result of assimilation (v. S. § 349).

For the occurrence of breaking before $l+$ cons. $v$. $\$ \S 12$, 15 , the only words in which it is found being sealla, and seolfa.

The only example of the metathesis of $l$ in the suffix -ils is gyrdils I. 6, VI. 8 .

fihles (panni) Pref. 2. VII (cf. Mt. IX. 16) is possibly a metathesised form of flyhtes (panni) II. 22 (v. $\$ 27.3$, Note).

huecl (quem) Pref. 4. XXVI is an error for huelc (v. CN.141). 
In Jicgendum (discumbentibus) XIV. 18, $\partial$ is a scribal error for $l$.

$m$.

8 88. The labial nasal $m$ occurs in various positions: mondo (cophinos) VIII. 19; unwisdom VII. 22; noma IX. 39; hersumiað IV. 41; smolt VI. 47; dumb IX. 17; somnung VI. 2; tempel XI. 16; ete.

Geminated: huommes XII. 10; temma V. 4.

Examples of the loss of $m$ before the surd spirants $f, p, s$ only: fif VI. 41 etc., fifligum VI. 40 etc.

Final $m$ is omitted in the MS. in dagu VIII. 31 (=dagum).

Final $m$ in wutum I. 38, XII. 7, beside wutun XIV. 42 is an instance of the preservation of the original ending of the $1^{\text {st }}$ pers. plur. of verbs, ef. Goth. nimam.

Final $n$ is written for $m$ in tegnun IX. 18; Jan eorঠ-cryple (dat. sg.) Pref. 2. VI.

$n$.

8 89. Examples of dental $n$ are: noma IX. 38; huon XIV. 35 ; sona I. 10; snytru VI. 2; londe VIII. 23; etc. Geminated: menn XIV. 21, monnes IX. 12; sunna IV. 6; synna II. 7 etc.

Guttural $n$ : stences XIV. 3; ðing VIII. 33; Joncungo VIII. 6; Juongum VI. 9 ; tunga VII. 33; etc.

$n$ has undergone metathesis in: fasne (fimbriam) VI. 56 (v. § 1. 4); risnelic IX. 11 (v. H. p. 38).

8 90. 1) Examples of the loss of $n$ before spirants are: -brohton XII. 16 etc.; uhte XIII. 35; pislico XIV. 40 (v. § 52.1); user IX. 22 etc.; stiðnise XVI. 14; suiðe IV. 33 etc.; gigoðe X. 20 (v. L. § 33); toðum IX. 18; uncu內 III. 10, IX. 32; $\hat{y} \delta$ IV. 37 ; etc.

2) Loss of final inflectional $n$, a characteristic feature of the North. dialect, is carried out with great regularity in:

a) Weak Nouns: haga (acc. sg.) XII. 1; heorta (dat. sg.) VII. 21 ; tunga (dat. sg.) VII. 33 ; ete. (v. \$§ 156-162). The only exceptions are: wacan VI. 48, Pref. 3. XIX, which may perhaps be considered as one, rather than two, as the word seems to have been copied into the Preface from the text (v. $\S 158$. II).

b) Weak Adjs.: خces alde Pref. 2. VII; خces êce III. 29 etc. (v. §§ 173, 174). 
c) Adverbs: hwona VI. 2; Jona VI.1; etc. (v. § 176.6, S. § 321 anm. 1). The only instance of the preservation of the final $n$ is in the compound utan ymb III. 34, VI. 6 (beside uta, ute, buta etc.).

d) Verbs, Inf.: forbeada IX. 39; gehera IV. 33; etc. (v. § 113). Pret. Subj. Plur.: gecuomo XVI.1; gesetta VI. 41; were III. 14; etc. (v. \& 121, beside Subj. forms in -on?).

foerdo (exeuntes) XVI. 8, and ge-hêrdo (desernientes) Pref. 2. IX would appear to be isolated instances of the loss of final $n$ in the Pret. Indic. Plur. (but v. S. $\S 364$, anm. 4 "Apokope des auslautenden $-n$ findet im north. nicht statt").

Final $n$ is lost in: seofa (septem) VIII. 8 etc. (4), seofo (4) (beside seofana, seofona (3) v. § 178); taco (signum) XIV. 44, (beside tacon XV. 26, Pref. 3. XXIV).

3) Loss of $n$ is due to scribal errors in: to-reded (scissum) XV. 38, Rushw. to-rended; una-drysendlic IX. 43 for un-adrysnendlic IX. 45 (v. § 27. 1); ondspyrendra (scandalizantium) Pref. 4. XXX for ondspyrnendra, ef. ge-ondspyrned VI. 3 etc. (v. § 27. 1); astigedon (ascendentes) VI. 32 for astigendon? Rushw. astaggdun wk. Pret. form (v. § 126); gesupedon Pref. 4. XXVII, the full gloss is hia $b$ gebirigdon $t$ gesupedon weron (gustaturos). A very common way of translating the Latin future participle is by the present participle (cf. passuri weron trowende two lines further down). May it not be assumed that what the glossator intended to write was gebirigdon (Pret. Indic.) $t$ gesupede (= gesupende) weron? The -on of the preceding gebirigdon might easily cause a scribe to repeat the ending -on and pat it in the place of $-e$. Moreover the fact that he uses weron immediately afterwards, proves that he intended to write a participle, not a preterite Indicative.

The form stanne XIV. 3, in the phrase stanne foel, might be written for stcene( $n$ ), with the common doubling of the consonant (cf. $\S 103$ ), or it might be the masc. instead of the neut. acc. form; of stcene faet is the form of the same phrase in Pref. 5. XLIV.

Beside the common forms drihten (dominus), drihtnes, which are of frequent occurence, occurs one example of the form without $n$ drihtes (domini) Pref. 1. 6.

$r$ is written for $n$ in fellera (pellicia) I. 6, Rushw. fellenne, ef. Mt. III. 4 gyrdils fillenu (sonam pelliciam), Rushw. fellen. 
Without any apparent reason an $n$ has been introduced in to-neardnum Pref. 5. XLII.

Chapter VIII. Non-Sonorous Consonants.

\section{Labials.}

p.

81. 1) Initial $p$ occurs in: plages Pref. 3. XVII, plagede VI. 22; and in the following loan-words: petro XVI. 7 etc.; penninges XII. 42, penningum VI. 37; portas VI. 6 ; posa $t$ poha (peram) VI. 8; ploeges Pref. 3. XVII; plontat Pref. 2. 5. It has disappeared in salmes Pref. 5. XL.

2) Medial and final $p$ occurs frequently. Examples are: scipo (ones) XIV. 27; geswipernise XII. 15; cempo XV. 16; hwoelpes VII. 28; geopnadon II. 4; godspell I. 14; scip I. 19; to-gegrap VII. 33. Loan-words: apostolas VI. 30; discipul Pref. 1. 2; sinapis IV. 31, senepis Pref. 3. XII.

Geminated: upp-eode IV. 6; upplocade VIII. 24 etc. (v. $\$ 10$. 2, Sw. H. E. S. § 399).

gefroppegedon (reuerebuntur) XII. 6, ef. Mt. XII. 10 is not clear.

No examples of the change of $p n$ to $m n$ occur.

$b$ is written for $p$ in biscob Pref. 2. 2; biscobas XV. 11 (v. C.N. 144 "biscopas alt. to biscobas"). $p$ corresponds to Latin ph in iosep XV. 45, beside iosephes VI. 3 .

b.

892. The sonant labial stop $b$ occurs:

1) initially: gebinda V. 3; bebod VII. 9; blind VIII. 17; brydguma II. 20 ; etc.

2) in the combination $m b$ : dumbo VII. 37 etc.; ombor XIV. 13 etc.; womb VII. 19 ; ymb IX. 14 ; etc.

3) geminated: $s i b b$ V. 34, IX. 50; hubba X. 21, habbað II. 17 etc. (simplified in habas (habete) IX. 50). No forms of WS. libban occur with $b b$, v. hlifiendra XII. 27 etc. (§ 136. 3, v. S. $\S 416$, anm. 2).

Inorganic $b$ inserted between $m$ and $r$ occurs regularly in: timber XIII. 1, -timbradon XII. 10 etc.; between $m$ and $l$ in: symble (semper) IX. 22, XIV. 17, but symle V. 4, 5, XIV. 7, $\mathrm{XV} .8$. 
Final $b$ in the prefix $y m b$ - as a rule remains: ymb-sceawde III. 5 ; ymbstondendum XIV. 47 ; ymb- beara VI. 55 ; etc., but ymoccurs in: ymsceavde XI. 11; ymstondendum XV. 35; ymbunden IX. 42.

Final $b$ is omitted in the MS. in: dum IV. 39, beside dumb VII. 32, IX. 17.

\section{$f$.}

8 93. The occurrence of the letter $f$ as the sign both of the voiceless and of the voiced labio-dental spirant gives little occasion for remark.

Examples of voiceless $f$ are: fola XI. 2; -frugnon X. 10; fif VI. 38; oft III. 10; etc. Voiced $f$ : on life VIII. 35; gelifde XVI. 11; hlafum VIII. 4 ; etc.

No examples of the change of $f n$ to $m n$ (v. S. $\S 193.2)$ occur: v. efne II. 2 etc.; stefn I. 3 etc.

$b$ where WS. commonly has $f$ appears in: februm I. 31, Pref. 2. V, febrende I. 30 (v. S. § 192, anm. 2, Bout. p. CXLII), in no instance with $f$; dioblas I. 34 etc. (6), (v. C. § 130), beside diowl III. 23 etc. (16), diowbla I. 32; ebolsas II. 7 etc. (8), beside efolsong VII. 22 (v. S. § 43, anm. 4).

$f$ is replaced by $\delta$ in: occcilla (lucerna) IV. 21 (v. § 3. 1, Bout. p. CL).

Final $f$ is omitted in the MS. in tuoel Pref. 2. X.

\section{Dentals.}

\section{$t$.}

8 94. The dental tenuis $t$ occurs frequently, simple, geminated, and in the combinations $s t, h t, f t$ etc.

Examples are: telgo IV. 32; twaem V. 13; eted XI. 14; at I. 34; styd I. 35; gaast XIV. 38; Jahtung III. 6; after I. 7; scaftes X. 6. Geminated: bytto (utres) II. 22; mitta (modio) IV. 21; sittende Pref. 4. XXXV. Simple $t$ appears in snotorlice XII. 34 .

8 95. WS. $t l$ in setl (v. S. $\S 196.2$ ) appears as $t l$ in: setla XII. 39; seatlas XI. 15; seatlum XII. 39 , and once as dl: sedlo Pref. 4. XXXIII.

The variation between final $t$ and $d 1$ ) in the prefix aet (cf. L. § 37) is as follows: at-eaude XVI. 14, beside ced-eauad IV. 
22 etc. (14); atgeadre II. 15, beside aedgeadre VI. 22 etc. (3); preposition, eet I. 16 etc. (6), beside oed VI. 55. - 2) in the Pron. hucet XIII. 11 etc. (29), beside huød XV. 14 etc. (14); huodhuoge XV. 24; with $d t$, hucetd XIII. 11 etc. (11), ef. gesadt (sedit) XVI. 19. - 3) in the sb. Jreat (turbam) V. 31 (16), beside treadd III. 7, V. 21 (v. C.N. 143 " treade alt. to treate"). - 4) in the Num. sextig IV. 20, beside sexdig IV. 8.

Beside the regular form unrôtsade (contristatus) III. 5, -rotsige VI. 26, -rotsia XIV. 19, occur the following forms where $t s$ is replaced by ds: un-rodsade VI. 26, un-rodsad VI. 50, geunrodsad X. 22.

Possibly the $d s$ is due to the analogy of bloedsade XIV. 22 etc. (7), where $d s$ occurs regularly, in no instance changed to $t s$ ?

For $d t$ instead of $t$ in un-rôdt XIV. 34, and bîdiende (discerpens) I. 26, v. Sw. H. E. S. § 391 (v. § 38. 3).

This $d t$ occurs further after a long vowel in getreadtaige (increpare) VIII. 32, but after short vowels in ge-scyrdte (breuianit) beside ge-scyrte XIII. 20; and in gescedt XVI. 19, which examples should perhaps rather be compared to hucetd above.

th is written for $t$ in: se scariothisca (scariot) XIV. 43.

to III. 23 is apparently miswritten for $t o$.

Final $t$ is omitted in the MS. in gaas (spiritus) XIII. 11.

d.

89. The dental media $d$ occurs frequently in all positions. Examples are: dead IV. 38; duru I. 33; bod XII. 28; vudu I. 6; drihten XII. 37; duolages XII. 27; hond VIII. 23; word VII. 13; etc. Geminated: biddend XIV. 35, gebidda Pref. 5. XLIII.

1) $\partial$ is written for $d$ in a number of instances: $\partial c r$ stes Pref. 3. XXIV, beside darsto VIII. 15 etc. (3); Jerne-leger VIII. 38, beside derne VII. 21 etc. (3); sunneðagana XVI. 2; milsanðe VI. 34; seðum IV. 31, beside sed IV. 27 etc. (5); acueðen bið Pref. 1. 15, gecuoeden woss XV.7, beside gecuoeden V. 36 etc.; cuoedon (dicunt) XI. 33, (in this case the mistake may be due to the scribe's confusion between the English verb ondueardon immediately preceding, in the preterite tense, and the Latin dicunt below in the present); sie gecostad IX. 49; gefriad bio Pref. 4. XXVIII; inlihteð waes Pref. 4. XXXIV; geðreað bıð 
(arguitur) Pref. 5. XLVI, beside sie geðread Pref. 4. XXVI; and frequently in proper names: bethsaiða VIII. 22; dauið XII. 37 etc. (4); heroð̌es III. 6; heroðis VIII. 15; iuðas XIV. 10, iuðas Pref. 5. XLIV; magðalenesca XV. 47, XVI. 9; zebeðies I. 19 etc. (3).

2) The North. form hundrad IV. 8 (v. S. § 327) occurs in three instances, beside hundradum VI. 21, margin.

3) ldl appears as $l l$ (v. S. § 197. 3) in: bal-lice XV. 43; and monigfallice Pref. 4. XXXII.

4) $d s$ remains in: gebloedsad XI. 9 etc. (7), (จ. S. § 198. 4); beside $t s$ in: gitsungas VII. 22 ; miltsa (miserere) X. 48 , and $l s$ in milsa X. 47 etc. (5).

For WS. lêeden occurs latin V. 41.

Beside styldon (stupebant) I. 22, occur the forms stylton VI. 51, fore-stylton XVI. 5, gestylte IX. 15 (v. C.N. 143 "gesttylde alt. to gestylte"), forstyldton V. 42, X. 24.

$t$ for $d$ occurs in: ondetenta VIII. 38; bið gesettet IV. 21, beside gesetted IV. 21; bið gemoetat IV. 19; fore-geðistrat VI. 52; awoendat were Pref. 1.11; uutetlice VII. 6, beside uutedIV. 11 ete. (19.)

Final $\boldsymbol{d}$ has disappeared in hoelen IX. 5; senden (mittentem) Pref. 5. XLI; Jaerfen (pauper) XII. 43. Rushw. Jorfende, ef. verse 42, Jorfend (pauper); in the compound word erenwreca Pref. 2. 1; and in gefregna (inquisita) Pref. 2.4=*gefregnad? (v. § 134. 4). to-sceade (disputans) Pref. 5. XLII seems to stand for to-sceade[nde].

For the prefix on- beside ond- v. § 74. VIII.

A parasitic $d$ after $l$ appears in asalde (asinæ) Pref. 4. $\mathrm{XXXV}$, beside asales IX. 42 .

ð.

89. As in the Durham Ritual (v. L. § 39), so here, the interdental spirant is, as a rule, denoted by $\delta$.

Exceptions are: the abbreviations $\mathfrak{p}=\delta a t$ I. 45 etc. (v. $\S$

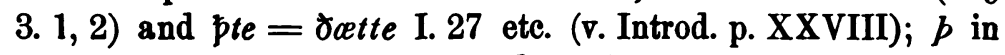
poet XIV. 3; pone IX. 25; and th in the following names: bethania XI.11, 12, XIV. 3; bethsaiða VIII. 22; nazareth I. 9.

Examples of $\partial$ in all positions are numerous: Jegnas II.

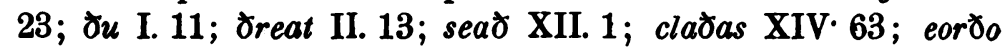




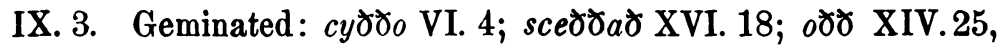
одðe XI. 30.

1) $d$ is occasionally written for $\delta$ : gecladed (nestitum) V. 15; coed (ait) XIV. 22; under-delfad IV. 19; hoefed (habet) IV. 25; sleped (dormit) V. 39, (จ. S. § 357); brodro III. 33; êdmodað IV. 41; fordon (enim) VII. 3; haedno Pref. 4. XXXIII, hødnum X. 33, 42, XIII. 10 ; sodlice XV. $44 ; d a$ X. 32.

2) Original $b l$ after a long vowel which in WS. became $d l$ (v. S. § 201. 3), remains in aðlo III. 10; and wiðlað VII. 23; beside adle V. 29, 34, I. 34; gevidlige VII. 15 etc. (5); nedles X. 25.

3) $\delta$ seems to correspond to WS. $d$ (cf. S. $§ 201$, anm. 1 North. fremठe WS. fremde) in gefremoiga (anathematizare) XIV. 71, the only example of the word given in B-T., and there unexplained. Rushw. has fremठiga. Does ge-fremठiga =WS. fremdian, intended for a literal translation of anathematizare?

Final $\partial$ is omitted in the MS. in cue[ $\partial]$ III. 3, v. C.N. 142.

$\boldsymbol{s}$.

89. Simple $s$, and $s$ combined with another consonant occur frequently, and call for no special remarks: sunu II. 10; aris II. 11; casere XII. 17; losiga III. 4; scyld III. 29; smyltnis IV. 35; snytru VI. 2; sprêc VI. 2; stonde III. 24; suce I. 2; gâstas V. 13 ; etc. Geminated: cyssende XIV. 45; and v. § 103.

sc occurs without metathesis: asca VI. 11; fiscum VI. 43; geascade VIII. 5, geuscadon XIII. 3. (For $x=h s$ v. § 102.4).

$t z$ where the Latin has $s$ occurs in the place name genatzeāं (gennesareth) VI. 53.

$r$ is written for $s$ in yrte (procella) IV. 37, "probably for yste" v. C.N. 142.

ic is a scribal error for is in: ic (est) XIV.23. For unful $=$ unsalt? v. $\$ 10.3$. Note.

\section{Gutturals and Palatals.}

$c$.

899. The guttural and palatal tenuis $c$ occurs frequently in various positions: calic IX. 41; corn IV. 31 ; ceorl XII. 25 margin; éc I. 38; rîc XIII. 8; reconlice I. 31; sceacerum XV. 7; clansunge I. 44; cnahtes IX. 24; fisces VI. 41; woerc XIV. 6 ; etc. Geminated: acced-win XV. 23; gewacce XIV. 37 etc. 
1) North. $h$ for final $c$ in unstrest syllables (v. Sw. H. E.S. § 540) occurs in: ah (sed) I. 44 etc. (46); meh I. 40 etc. (5), (beside mec 32); خeh IX. 43 etc. (3), (beside خec 14); iwih I. 8 etc., iuh VI. 11 etc., without exception; usih Pref. 1. 13, (beside usic 5).

2) $g$ for $c$ occurs in: usig I. 24, wusig XI. 9 (beside usih 1, usic 5); huulig XIII. 1 (beside hulic V. 16); arlig (mane) Pref. 5. 16 (beside arlice XVI. 2 etc.); wlonga (dinitum) Pref. 4. XXXII, (beside wlonca X. 25, XII. 41); and $g c$ in: on bacg (retro) XIII. 16 (on bacc VIII. 33); gebraegc (fregit) VI. 41 (v. § 103); huced iuh jincge (uidetur) XIV. 64.

3) $c h$ for $c$ (v. S. § 210. 3. 4) occurs in: mech VIII. 34; michil V. 11, michelo IV. 37, 39; carchern VI. 17 (beside carcern VI. 17).

Initially in: channanesca (cananaeum) III. 18.

$g$.

8 100. Examples of $g$ in all positions are numerous: god IV 20; daeg IX. 31, dagum IX. 2; Jiostrig VIII. 17; wealigo XII. 41 ; arg VIII. 38 ; oferhygd VII. 22; tostrogden XIII. 2; ongeaegn XI. 2; Jegnas VI. 1'; etc. (For magden, maeden etc. V. below.)

Geminated $g$ is written $c g, c c(c)$, and $g c$. a) $c g$ in: bycges VI. 36, bycge VI. 37, bycgendo XI. 15, bebycgendra XI. 15; licgende II. 4, licgendum XIV. 18; saecgende Pref. 1.6.

b) $c c$ (c) in: bebycendo XI. 15; liccende VII. 30, licende V. 40, Pref. 5. XLI, $\mathfrak{p}$ бu ne dernelice (adulteris) X. 19.

c) $g c$ in: ascegcas XIV. 12, fore-sagcane XIII. 10.

gg appears in twigge XIII. 28, twiggo IV. 32, and in the Scand. loan-word ge-eggedon XV. 11.

1) Final $g$ remains unchanged to $h$ (v. S. $\S 214.1$ ) in: beg XV. 17; oferstag V. 21; burg II. 1; etc.

2) Medial $g$ is lost in: maden V. 39 etc. (4), (beside mregden V. 41 etc. 7); gehrino (aedificationes) XIII. 2 (v. §23.4, Note. B-T. gerên); on merne (mane) XV. 1 (v. S. § 214, anm. 10).

3) Medial $g$ appears as $h g$ in mohge VII. 15 (beside mage IX. 39 etc.).

4) The ending -ig is shortened to $i$ (v. S. § 214. 5) in: swyndria (singillatim) XIV. 19, siundrio Pref. 1.13, sunduria XIV. 66 (beside suindrige IX. 2 etc. (4). 
5) $g$ in the combination $n g$ appears as $c, c g, g c$ in the following words:

a) $c$ in: onfence VI. 41 (beside onfenge XVI. 19); glencas XIII. 2; genyncerde (esuriit) XI. 12 (with $w$ miswritten for $h$; beside hyngerde II. 25); stencum (lignis) XIV. 43, (beside stengum XIV. 48); ofer-mercunc Pref. 4. XXXIII; lesinc (redemtionem) X. 45 ; Jrounc (crucem) VIII. 34 (v. $\$ \S 68,82$. I. 3). VI. 48.

b) $c g$ in: brencgas IX. 19; lond-bigencgum XII. 1; rowincg

c) $g c$ in: lengc V. 35; espryngc V. 29. sc in utiorninsc (pro$\mathrm{flu}[\mathrm{n}] \mathrm{io})$ V. 25 is perhaps written for $g c$.

h.

8 101. For the sound-value of initial $h$ in North. ef. L. $\S 44$. As in the Durham Ritual, so here, an $h$ is often written before $l, n$, and $r$, and occasionally before vowels, where it is not historically correct; and on the other hand historical $h$ is sometimes dropped before $l, n, r$.

1) The examples of inorganic $h$ are: a) before $l$ : $h l a f$ (uxorem) VI. 17, 18, XII. 19 (2), hlaf (reliqua) IV. 19, VI. 43 (beside lafe uxore Pref. 5. XXXIX); hloetmest XII. 6 etc. (5), (beside loelmest XVI. 14); behleing (proditione) Pref. 5. XLIV (=WS. belêening v. § 44. 2); ungehleaffullnisse Pref. 5. XXXIX (beside geleafful- (6), geleafo etc. (8); hleat V. 22 (beside -leat II. 12), hluton III. 11, -hlutende I. 7; hlifige V. 23, hlifiendra XII. 27 (beside lifgiende Pref. 1. heading, gelifde XVI. 11); gehliored XIII. 31 etc. (3), (beside geliored XIII. 30 etc. (3) v. § 125. I).

b) before $n$ : hnetla (retia) I. 16 (beside nettum I. 18, 19).

c) before $r$ : hroes (impetu) V. 13 (beside -ras IV. 37, raesdon III. 10); hraste (cessauit) IV. 39, hrast- III. 4 (beside raestas XIV. 41 etc. (5), rost- II. 27 etc. (3); gehreafadon XV. 20 (beside reafud III. 27 ete. (3); hrecone V. 29 etc. (4), (beside recone I. 29 ete. (7); gehrino (aedificationes) XIII. 2 (Rushw. gerino v. $\S 23$, Note); in rode (cruce) XV. 30 an initial $h$ was written and afterwards struck out, v. C. N. 144 "hrode alt. to rode".

d) before vowels only in: geharn (currens) XV. 36 (beside -arn X. 17 etc. (4); hiurum (uestris) II. 8 (beside iurum VI. 11).

2) $h$ has been dropped in the following instances a) before l: lafo (panes) VIII. 5 (beside hlafo VI. 37,38 letc., v. 
$\$ 143$. I. c. masc. plurals in -0 ; but can the frequent occurrence of $-o$ in this word be due to confusion with $l a f$, pl. $l a f o$, the $h$-sound being so weak that hardly any difference was felt between the two words?); linigiendo II. 15, gelionede II. 15 (beside hlingendum VI. 22, hlinigendum XVI. 14, gehlionade XIV. 3). b) before $n$ : nesc XIII. 28. c) before $r$ : reof (leprosus) Pref. 2. VI, riofol I. 42 (beside hreafes (leprosi) XIV. 3); rode (calamo) XV. 36 (beside hreade XV. 19, v. §49, Note).

Before vowels $h$ is lost only in the common contractions: nabbas VIII. 17, noefde IV. 5 etc.

3) In all other examples initial $h$ is found regularly: hlaf (panem) VI. 8 etc.; in-hlogan V. 40; gehran VII. 33; hrof XIII. 15; hwoet I. 24; halig I. 8; hit IX. 10; etc.

$w$ is a scribal orror for $h$ in genyncerde (esuriit) XI. 12 (v. § 100.5 a).

Medial and Final $h$.

8 102. 1) Medial $h$ and $h w$ before vowels are regularly lost (v. S. § 218): gefoanne XIV. 48; geseanne V. 14 etc.

2) Geminated $h$ does not occur, simple $h$ is found in: eher IV. 28, ehera Pref. 2. VIII; teherum IX. 24; poha VI. 8 (v. S. $\S 220$ and anm. 1).

3) $h$ in the combination $h t$ occurs as a rule unchanged: cnoht IX. 36 etc.; gefehto XIII. 7; noeht XIV. 30 etc. Exceptions are: docter (filiam) Pref. 3. XXI; lecht (splendorem) XIII. 24; moeghte (uirtute) IX. 1.

4) $h s$ appears regularly as $x$ (v. S. \$ 221. 2) in: lixendo IX. 3; sex IX. 2, sextig IV. 20, sexdig IV. 8; woexende IV. 8; etc. But the $h$ is lost in wastm IV. 7 etc., and in the North. form seista XV. 33 (v. S. § 221. 2).

5) $h$ is lost (v. S. § 222 and anm.) in: heista V. 7; nesta XVI. 14 etc.; heum XIII. 27 (hehum XIV. 43), hera X. 43, heanisse IV. 5, heanissum XI. 10, heannise XIII. 27 (S. § 222, anm. 2); geneolecde I. 31 etc.; neawung XIII. 28 (v. § 82. II); bitwien IV. 41 , bituen VIII. 16 (v. S. $§ 329$ ); and in the $2^{\text {nd }} \& 3^{\text {rd }}$ pers. sg. Pres. Indic. of contract verbs: onfoas X. 15, onfoed VI. 11 etc.; خu gesiis XII. 14, бu gesiist V. 31 (cf. L. \$ 44. 2).

$h$ is preserved in sih $\delta_{0}$ IX. 9 .

6) Final $h$ and $h=h w$ is regularly preserved (v. S. \&223): feh XIV. 11; neh X. 46; wohfullum XV. 28; ataeh (oducens) XIV. 
47; fore-floch (profugit) XIV. 52; gesaeh VIII. 33 etc., gesih (uide) I. 44 etc.

No example occurs of final $h$ written $g h$.

Gemination of Consonants.

8103. Great irregularity prevails with regard to the occurrence of geminated consonants (cf. L. § 45). In some cases where consonants should be written geminated they are written simple, and much more frequently vice versâ (v. S. § 230 , anm.), this variation occurring often in the same word. In such forms as awritten, gegrippen, -slittnise the inorganic gemination of the consonant may be meant for a sign that the preceding vowel was short, but on the other hand such forms as brucca, sleppende, slitted show that the scribe was following no consistent method for the indication of vowel-length.

Examples are:

I. Consonants in WS. geminated, in St. Mark written simple:

1) After short vowels: $b, b b$ : habas (Imp. pl.) IX. 50, (beside habbað etc. (v. § 136. 1); d, dd: خirda IX. 31, beside бirdda X. 34 etc. (4); l, ll: sele XIV. 18 etc. (5), beside selleð XIII. 12 etc. (2), geselenne Pref. 4. XXXVIII, beside sellanne X. 40; $n, n n$ : losane (Inf.) I. 24 etc. (6), beside -anne (35), (v. § 114); monum XI. 18, 30, beside monnum X. 27 etc. (5), - $a(7),-o(10)$, -es (16), (for monn v. § 104); sunigo II. 15, beside synnig III. 2 etc. (4); meto VII. 19 , beside metto (cibos) VI. 36 (v. S. $\$ 263$, anm. 3, 5); -seton ${ }^{1}$ (wk. vb.) VI. 56, VIII. 6, XV. 19, beside -setton VI. 29 etc. (5).

2) After long vowels: $d$, $d d$ : ladon VI. 29 etc., beside laddon XI. 7 etc. (v. $\S 132$. II); heanise IV. 5 etc. (2), beside heannise XIII. 27 (v. S. § 222, anm. 1, 2); wraeঠo III. 21, beside wrą $\gamma_{0}$ III. 5.

II. Consonants which are simple in WS., in St. Mark geminated :

1) After short vowels: $c c, c$ : -bracc VIII. 6, 19, braecg VI. 41, beside -brac V. 4 etc. (2); on bacc (retro) VIII. 33, bacg XIII. 16; maccalic VI. 21 (v. § 1. 5); onsacca Pref. 1. 15, VIII. 34, XIV. 31; onsaec (adj.) XIV. 30, beside onsac XIV. 72;

1 Rushw. has: settun VI. 56, to-gesetun VIII. 6, settun XV. 19. 
sprecca XII. 1 ete. (7), beside spreca I. 34 etc. (14), (v. $\$ 128$. I), spracc IV. 34 , VIII. 32 , beside spraec II. 2 etc. (3); ఫceccilla IV. 21; wurcecce (torqueas) V. 7; $d d, d:$ gebedd (orationis) XI. 17, gebeddes XII. 40; badd (rogabat) X. 17 etc. (3), beside bad I. 40 etc. (5); goddes (dei) IX. 1 etc. (3), beside godes I. 1 etc. (29); glcedd-môd X. 49, beside glæanise IV. 16; hwidder XIV. 12 etc. (2), beside hwider VI. 10 etc. (2); gg, g: Iwigge XIII. 28 etc. (3); ll, l: allne VIII. 36 etc. (2), allra XII. 33 etc. (7), beside alra XII. 22 ete. (7), (but v. S. § 231. 2, v. all below § 104); camelles I. 6 , beside camel X. 25 ; willt VI. 22 , beside wilt I. 4, X. 51 ; willnias XIV. 63 etc. (3), beside wilnig VI. 22,$25 ; \mathrm{mm}$, $m$ : cummende XV. 21 , beside cumad III. 19 etc. (4); cymmende XIII. 26 etc. (3), beside cymende II. 13 etc. (4); gecymmes ( $3^{\text {rd }}$ sg.) XIII. 36, beside cymes I. 7 etc. (10); niommanne III. 27 etc. (2), beside nioma II. 2 ete. (3); nimmet ( $3^{\text {rd }}$ sg.) II. 21 , beside niomað IV. 15; geniomme (subj. sg.) XIII. 15; summ XIV.47, 57, beside sum IX. 38 etc. (8); summe VIII. 3, XIV. 65, beside sume VII. 1 etc. (10); nn, n: Pres. Parts. wynnennde VI. 48; cyssennde XIV. 44, beside cyssende XIV. 45 etc.; inn-eode V1. 25 etc. (16), beside in-eode VI. 22 etc. (31); moslenn XII. 41, beside moslen VI. 8 (WS. moestling V. \$ 68. 2): hreconne VIII. 10, beside recone I. 29 etc. (7); ठegnna Pref. 5. XLVI, beside ðegne Pref. 4.XXXV etc.; $p p$, $p$ : clioppadon VI. 49 , beside cliopia X. 47 etc. (9); clioppende V. 7 etc. (6), beside cliopende I. 3, V. 5 ; -crypple II. 5 etc. (3), beside -cryple II. 9 etc. (3); earelipprica XIV. 47, beside earliprico VII. 33 (v. § 7.2); gegrippen I. 31; scipp IV. 1, 37, 38, Pref. 2. IX, beside scip V. 2 etc. (15); rr, $r$ : forrma XVI. 9, beside forma XIV. 12; (iuerra (acc. pl.) XI. 25, beside iuero XI. 26); ss, $s$ : Abstracts in -niss, monncualmniss XV. 7, beside -nis (5); -nissa, -e, -um (26), beside -nise etc. (63); -nesse etc. (3), beside -nes, -nese (5); ecnisse III. 29, beside ecnise XI. 14, cyðıisse XIV. 55, beside -cyðıise XIV. 56 (v. § 67); бassum XIV. 60, ठissum XI. 23, beside ठisum VIII. 12 etc. (5), (v. S. $\S 338$ ); wossanne (esse) IX. 5, beside wosa IX. 35 etc. (8); $t$, : eatta, ettanne VI. 37 etc. (12), beside eata, eteঠ VII. 2 etc. (5), (v. §.128. I); fatt IV. 21, beside faet IV. 21 etc. (4); fattro V. 4 (v. § 13. 3), beside feotrum V. 4 (ef. S. § 228); -frealtas XII. 40; begeatta XIV. 2; ongalt II. 8, beside -gat Pref. 4. XXVII etc. (4), (v. § 128. II); agotten II. 22; hlott (sortem) XV. 24; gescett XIII. 3 etc. (6), -scedt XVI. 19, beside -sat XI. 2 etc. (4); selt (sb.) 
I. 32; slittnise XIII. 14, beside -slitnessa II. 21 (v. § 8. 2); wulla (scire) VII. 24, Pref. 1. 7, beside gewula IX. 30 etc. (14), (v. § 137. 1); awritten I. 2 etc. (9); writto (sb.) XIV. 49, ge-wuritlo XII. 24, beside writ XII. 10, gewrit XV. 28.

2) After long vowels: $c c, c$ : brucca (Inf. and Subj. sg.) XIV. 12,14 , beside brûca III. 20 etc. (3); pp, $p$ : sleppende XIV. 37 , beside slepende IV. 38 etc. (4); ss, $s$ : bissen VII. 17 , beside biseno IV. 34 etc. (3); arisse XVI. 14 (v. § 38. 3); gristbitteð IX. 18; etton VII. 3,4 , beside eton VIII. 1 etc. (6); frelton IV. 4; agaett (effudit) XIV. 3 (v. §56. 1); lyttelra VIII. 7, X. 15, beside lytel I. 19 etc. (6); setton (sedebant) III. 34 ; -slittes, $-\gamma$ XV. 29, II. 22, beside slites IX. 18 etc. (3); Jrittig IV. 8, 20 (but v. S. § 230, anm.).

$\S 104.1)$ Historical gemination at the end of a word is as a rule not simplified, as it generally is in WS. (v. S. § 231.1).

Examples are: blann IV. 34, VI. 51, blinn VII. 27; cann XIV. 68, 71; ongann VIII. 25 etc. (22); wann Pref. 1. 10; bedd (lectum) VII. 30, XIV. 15, beside bed IV. 21; cynn IX. 29 etc (6); ellðiodade XIII. 34; gytt (sb.) Pref. 3. XIV (cf. S. § 263, anm. 3); sibb V. 34, IX. 50; synnfullo II. 15 etc. (3), beside synII. 16, 17; all I. 5 etc., allswa XIV. 48, allne VIII. 36, XVI. 15 (allra v. § 103. II); fearr XII. 1 etc. (4); fullwihtere VI. 14, beside fuluihtere VIII. 28, fuluiht I. 4 etc. (10); -geleaffull IX.19, geleaffullnise Pref. 4. XXVIII etc. (3), fyllnise Pref. 1. 14 etc. (2), beside -geleaffulnise XVI. 14 etc. (3), -sceomfulnise VII. 21, fylnise Pref. 1. 9; monn I. 22 etc. (23), menn I. 25 eic. (21), beside mon XII. 34 etc. (4), men VII. 36; bispell IV. 10 etc. (5), godspell I. 14 etc. (8). Final $l l$ is simplified in the Scand. loanword trael X. 44 etc. (3), beside trcellum XIII. 34 (v. Kluge, P. G. I, p. 786).

2) Simplification appears irregularly in certain unstressed syllables (v. S. § 231. 4), and compound words.

The examples are:

a) unstressed syllables: of $t \iota$ in: ondete VIII. 38 etc. (5) (fallelande V. 5, v. Note); $l l$ in: deglice IX. 28; $n n$ in: ahongene (acc. sg. m.) XVI. 6; and with syncope of the middle vowel cuoedne XIV. 58, gehatne Pref. 1.15 ; nn remains in: byrgenne VI. 29 etc. (7), bebyrgennise XIV. 8; geðungennise Pref. 2. 6, beside gecoreniso Pref. 2.1 ; Jyrnenne XV. $17 ; r r$ remains in: afterra IV. 19 etc. (3). 
Note. fallelande in the gloss falletande $t$ raerscende (concidens) V. 5 is apparently a derivative in -etlan from fallan. The concidens of the toxt is concidens = 'cutting, beating' etc, and in the sense of 'beating' it is correctly glossed by Jaerscende. But apart from the context concidens might be conctdens = 'falling down', and it was probably this word which the glossator had in his mind when he wrote falletande. He knew that a form concidens could have two different meanings and he wrote both down, ef. $\S 19$. 1, Note. The simple $d$ in medo (medios) VII. 31, Rushw. middum is probably due to confusion with the Latin word, as is the vowel $e$ for $i$ (

b) compound words (v. S. § 231. 3): wildeora Pref. 1. 12, beside wilde deorum I. 13; feltun VII. 19; hunteantig X. 30 etc. (2), beside hund-teantig-, Pref. 4. XXXII; wyrtruma IV. 6 etc.

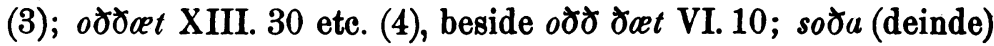
IV. 17, beside soðða IV. 28 etc. (3); ठъesas (maris) V. $1=$ ðaes saes. 